\title{
الصورة الذهنية لجامعة تبوك في الصحف السعودية وعلاقتها بصورتها الذهنية لدى \\ العاملين بها
}

د. محمد فؤاد محمد زيد

استهدفت الدراسة الحالية التعرف على العلاقة بين الصورة الذهنية التي تعكسها

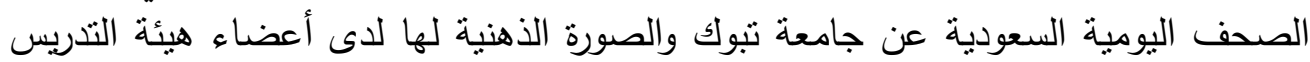
والموظفين بها، واعتمدت على منهج المسح بالعينة بشقيه التحليلي والميداني، واستخدم كل من تحليل المضمون والاستيبان في جمع بيانات الدراسة وطبقت الدراسة التحليلية على عينة

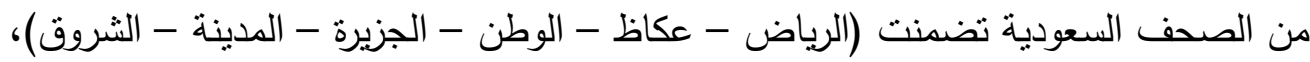
وطبقت الدراسة الميدانية على عينة دن أعضاء هيئة التدريس والموظفين بجامعة تبوك بلغ الغ ولغ

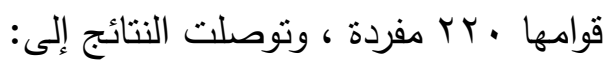

- وجود علاقة دالة إحصائيا بين تعرض المبحوثين لأخبار الجامعة بالصحف السعةدودية وإدراكهم لملامح الصورة الذهنية التي تعكسها هذه الصحف عن الصن الجامعة.

- وجود علاقة دالة إحصائيا بين معدل تعرض المبحوثين لأخبار الجامعة بالصحف وكل من؛ إدراك العاملين بالجامعة لواقعية الصورة المقدمة بالصحف عن عند الجامعة، وتقيبيم العاملين بالجامعة لأدائها.

- وجود فروق دالة بين متوسطات درجات المبحوثين في إدارك المالامح السلبية لصورة

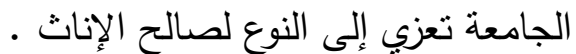

The mental image of the University of Tabuk in the Saudi newspapers and its relation to mental image among its employees

The current research aimed to identify the relationship between the mental image reflected by the Saudi newspapers and the mental image of the University of Tabuk and its faculty members and staff. The research was based on the survey methodology, both analytical and field. The analysis of the content and the questionnaire was used to collect the study data. A sample of Saudi newspapers (Riyadh, Okaz, Al-Watan, Al-Jazirah, Al-Madinah, AlShorouq) was applied to a sample of $r$. faculty members and staff at Tabuk University. The study reached several results, the most important of which are:

There is a statistically significant relationship between the subjects' exposure to the university's news in the Saudi newspapers and their understanding of the mental image that these newspapers reflect on the university.

- The existence of a statistically significant relationship between the rate of exposure of the subjects to the news of the university in the newspapers, and each of the employees' awareness of the reality of the picture presented in the newspapers about the university and the evaluation of the university staff for its performance.

- There are significant differences between the average scores of respondents in the perception of the negative aspects of the university image attributed to gender in favor of females. 


\section{مقدمة}

تقوم وسائل الإعلام بدور كبير في مجال صنع وترويج الصور الذهنية المنطبعة لدى الجماهير عن الثخصيات والمؤسسات إلى الحد الذي يشعر فيه المتلقي أنه التقى فعلا

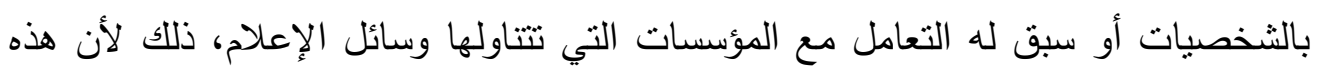

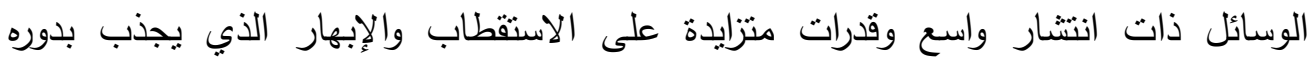
الجمهور لمتابعتها والحصول من خلالها على الكثير من المعلومات عن الثخصيات

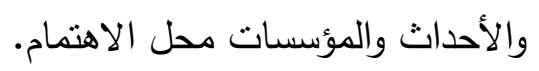

وتعد وسائل الإعلام ضمن العوامل المؤثرة في بناء الصورة الذهنية للمؤسسة ذلك أن الن ألمات الجهود الإعلامية للمنظمات وتأثثرها على صورة المؤسسة نفسها، ومدى سلبية أو إيجابية التغطية الإعلامية للأحداث الخاصة بالمؤسسة في وسائل الإعلام الجماهيرية، وحجم الاهنمام التي تكنه وسائل الإعلام الجماهيرية بأخبارها من العوامل المهمة في بناء صورة المؤسيسة

لاى الجمهور (') - (')

والصحف إحدى المؤسسات الهامة في المجتمع من خلال ما تقدمه لأفراده من معلومات

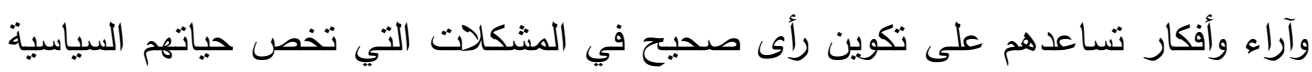

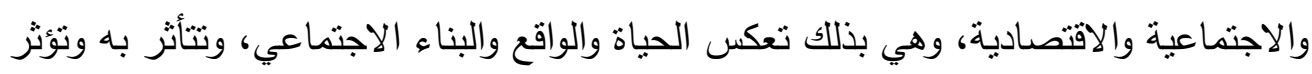

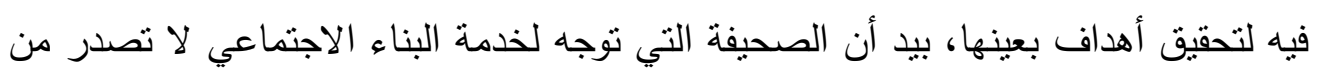

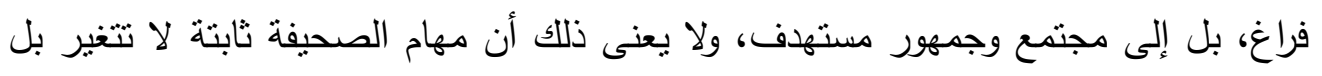

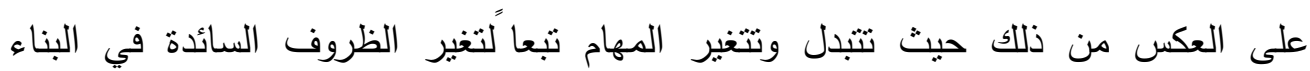
الاجتماعي وتبعاً لتغير واختلاف خصائص الجمهور الذي توجه إليه(ب).

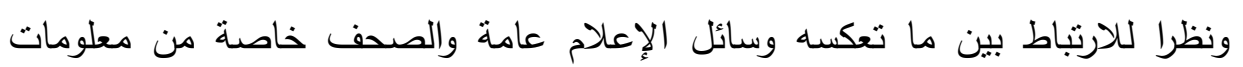
ومواد قد تسهم في بناء الصور الذهنية عن المؤسسات عامة والتعليمية خاصة وما يعتقده

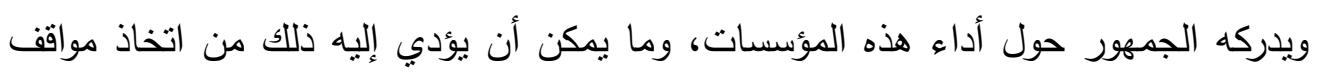

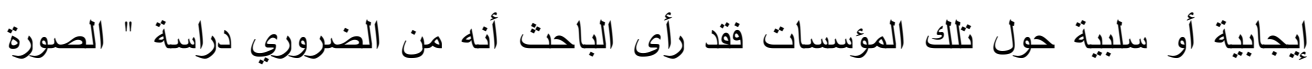
الذهنية التي تعكسها الصحف السعودية عن جامعة تبوك وعلاقتها بصورتها الذهنبة لدى أعضاء هيئة التدريس والموظفين بها، للوقوف على دور الصحف في تشكيل الصورة الذهنية

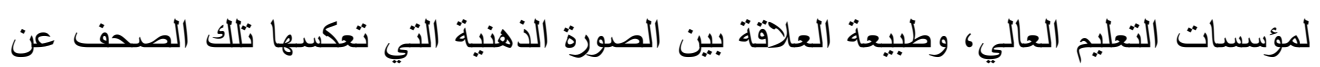
الجامعة والصورة الذهنية كما يدركها الجمهور الداخلي للجامعة عنها. 


\section{مشكلة الاراسة:}

تؤدى وسائل الإعلام دوراً كبيراً في الطريقة التي نبنى أو نشيد بمقتضاها تصورنا للعالم،

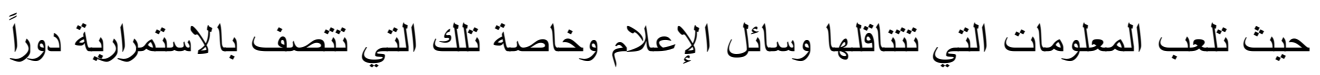

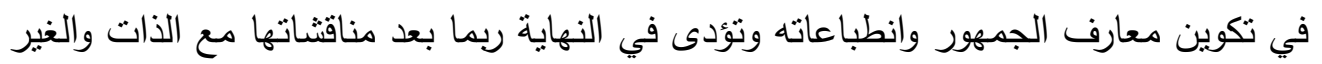
إلى تشكيل الصور العقلية التي تؤثر في تصرفات الفرد(ّاء).

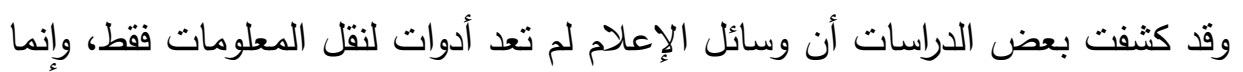

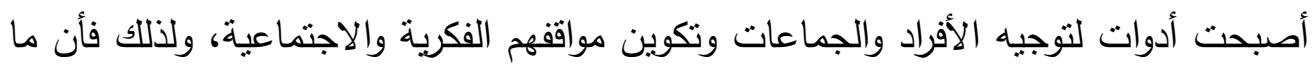
يقرب من (•V\%) من الصورة التي يبنيها الإنسان لعالمة مستمدة من وسائل الإعلام المختلفة وفي مقدمتها الصحف (ء). وبنظرة فاحصة لما ينشر بالصحف حول ما تقوم به الجامعة من جهود وما تئديه من أدوار نجد أن بعض الصحف قد تسهم في تكوين صورة ذهنية سلبية عن الجامعة وهو ما يضر بسعي هذه المؤسسات للقيام برسالتها التي تتضمن تقديم تعليم متميز لأبناء الوطن

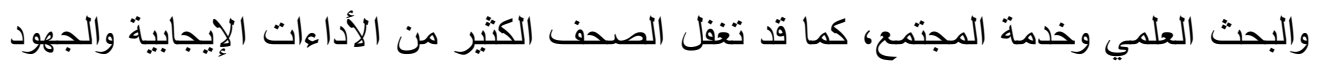
المشرقة لبعض الجامعات.

وعلى الرغم من أن مهمة وسائل الإعلام باختلاف صورها، هي إبراز كافة الجهود وبيان

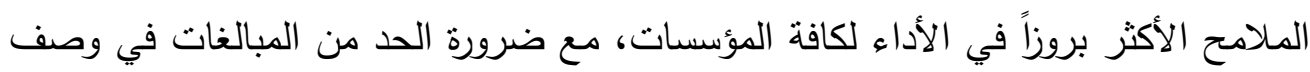

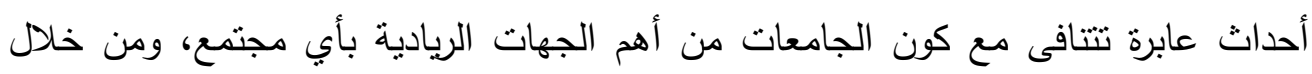

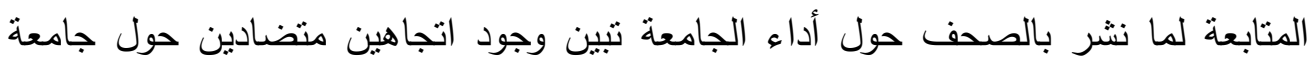
تبوك أحدهما مشرق إيجابي، والآخر قاتم سلبي، حيث أن الصورة التي تتكون عن الجامعة

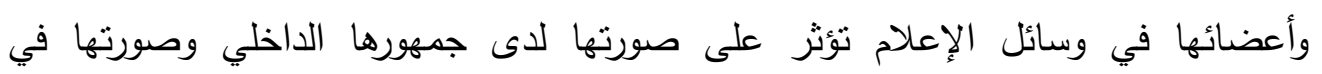
المجتمع بشكل عام.

ومن هنا تتحدد مشكلة الدراسة؛ في محاولة الكثف عن طبيعة الصورة الذهنية لجامعة تبوك كما تعكسها الصحف اليومية السعودية، ومعرفة دور الصحف اليومية في تكوين هذه

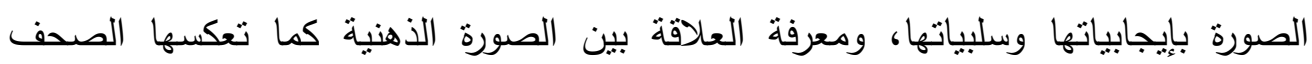
اليومية بالمملكة العربية السعودية عن جامعة تبوك وصورة الذهنية لدي العاملين بها. 


\section{وتتلخص مشكلة الدراسة في التساؤل الرئيسي التالي:}

ما العلاقة بين الصورة الذهنية التي تعكسها الصحف السعودية لجامعة تبوك وصورتها

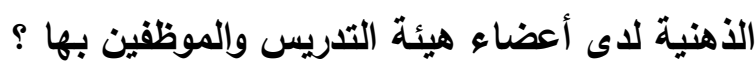
وينبئق منه التساؤلات الفرعية التالية:- مـا العلاقة بين تعرض المبحوثين لأخبار الجامعة بالصحف السعودية وإدراكهم لملامـح الصورة الذهنية التي تعكسها هذه الصحف عن الجامعة ؟

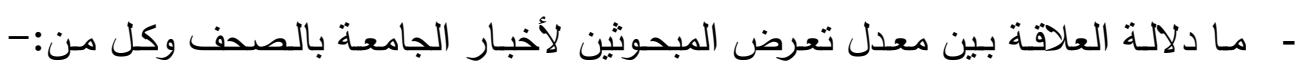
إدراك العاملين بالجامعة لواقعية الصورة المقدمة عن الجامعة بالصحف. ، نقييم العاملين

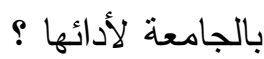
- هل توجد فروق ذات دلالة إحصائية بين متوسطات درجات المبحوثين على الدرجة الكلية

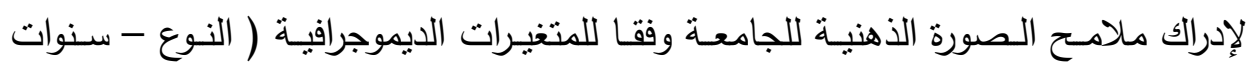

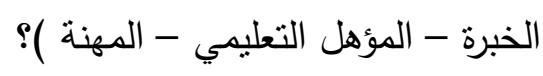

- ما أنواع الصور الذهنية التي تعكسها الصحف عن الجامعة ، وما اتجاه المضمون المقدم

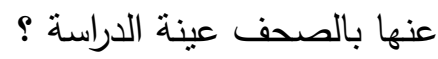
ما الفنون والأثكال التحريرية التي قدمت من خلالها الموضوعات عن الجامعة بالصحف

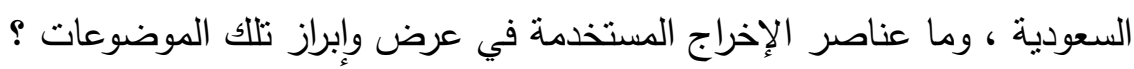

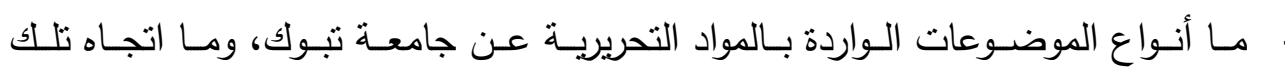

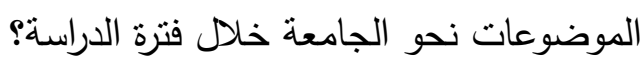

ما طبيعة الصورة العامة للجامعة في الموضوعات الواردة حولها بالصحف ؟

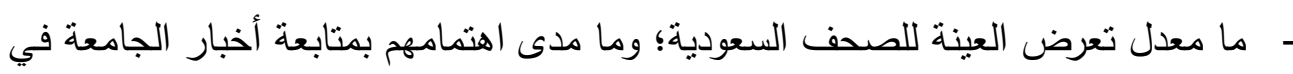
هذه الصحف، والوقوف على مصادر حصولهم علي الأخبار والمعلومات التي تتعلق بالجامعة؟ ما الملامح الإيجابية والسلبية لصورة الجامعة التي تعرضها الصحف بالمملكة من وجهة

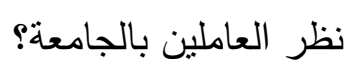
- مـا مدى اقتتاع المبحوثين بواقعية الصورة المقدمة عن الجامعة بالصحف ومدى تقبلهم

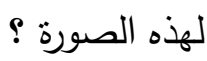
- ما الصورة العامة لجامعة تبوك لدى العاملين بها ؟ لمهوة 
تعد أهمية الصور الذهنية في أن العقل لا يمكن أن يحتفظ بكل ما يتعرض له -هبكل

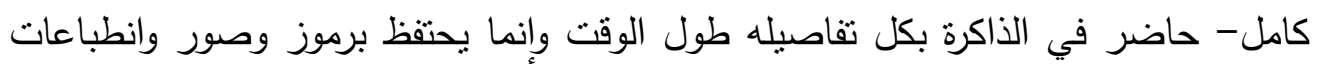

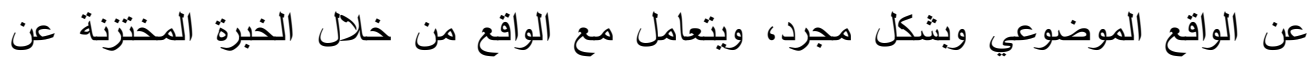

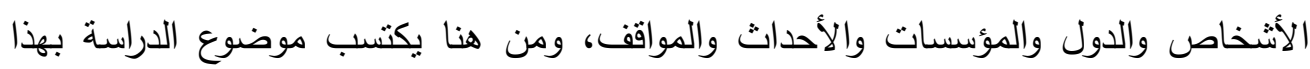
التحديد أهمية خاصة في الوقت الراهن على ضوء الاعتبارات التالية:-

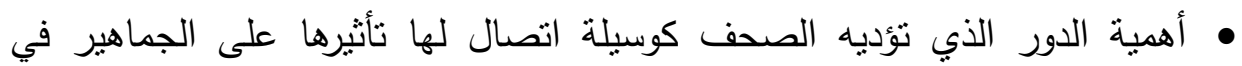

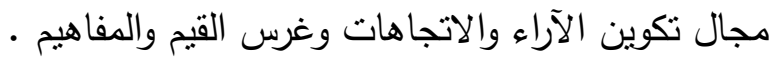

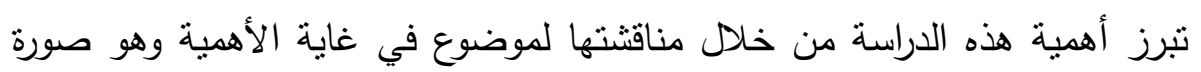

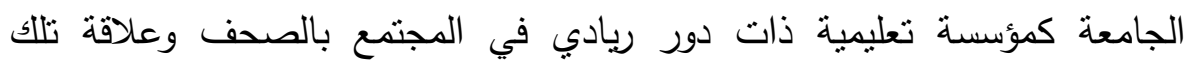

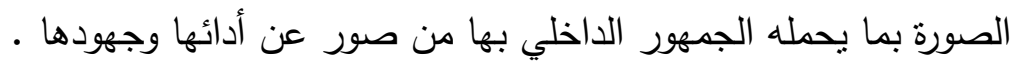

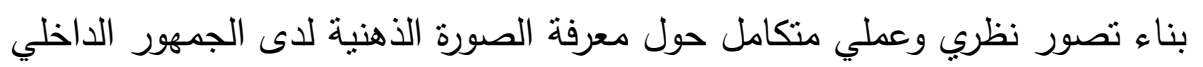
للجامعات ومعرفة مكوناتها وأهميتها وعوامل تكوينها وتقويمها بالنسبة للمؤسسات

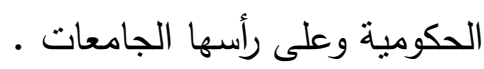
قلة الدراسات التي اهتمت بدراسة العلاقة بين الصورة الذهنية التي تعكسها الصحف

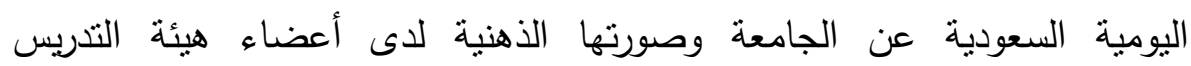

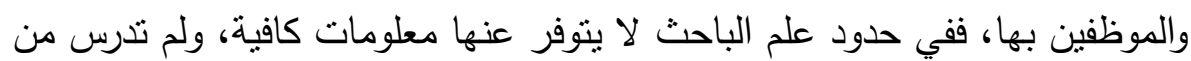
قبل . إثراء المكتبة البحثية بهذا النوع من البحوث عن مفهوم الصورة الذهنية عن الجامعات

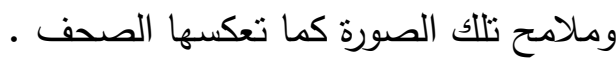

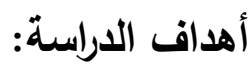

تتركز أهداف هذه الاراسة في التعرف على العلاقة بين الصورة الذهنية التي تعكسها الصحف اليومية السعودية عن جامعة تبوك والصورة الذهنية لها لاى أعضاء هيئة التدريس والموظفين بها، وذلك من خلال:

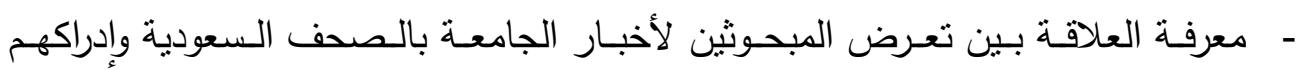
لملامح الصورة الذهنية التي تعكسها هذه الصحف عن الجامعة . 
- الوقوف على العلاقة بين معدل تعرض المبحوثين لأخبار الجامعة بالصحف وكل من:-

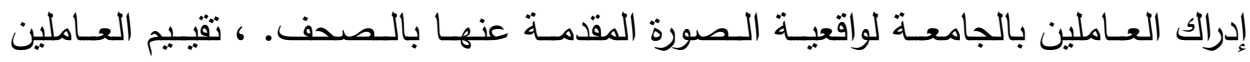
بالجامعة لأدائها . - ت تحديد دلالة الفروق بين متوسطات درجات المبحوثين على الدرجة الكلية لإدراك ملامـح الصورة الذهنية للجامعة وفقا للمتغيرات الديموجرافية ( النوع - سنوات الخبرة - المؤهل

$$
\text { التعليمي - المهنة ). }
$$

رصد أنواع الصور الذهنية التي تعكسها الصحف عن الجامعة ، وتحديد اتجاه المضمون

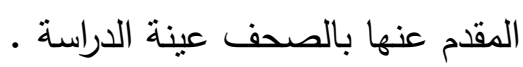
ـ ـ رصــ الفنـون التحريريـة التـي قدمت مـن خلالهـا الموضـوعات عـن الجامعـة بالصحف

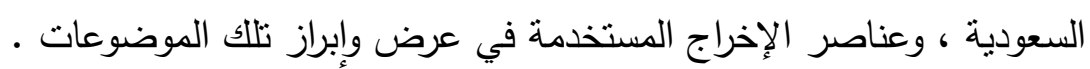

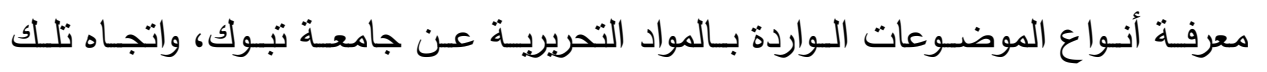

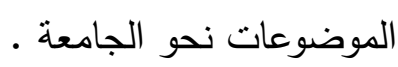
- تحديد الملامـح الإيجابية والسلبية لصورة الجامعة التي تعرضهـا الصحف بالمملكة من وجهة نظر العاملين بالجامعة، - معرفة مدى اقتتاع المبحوثين بواقعية الصورة المقدمة عن الجامعة بالصحف ومدى تقدبلهم

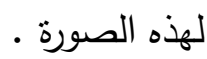

\section{مفاهيم ومصطلحات الاراسة:}

تتعامل الدراسة الراهنة مع مفهومين أساسيين هما: مفهوم الصورة الذهنية، الصحف السعودية ، وفيما يلي توضيح لحدود استخدام هذه الدراسة لتلك المفاهيم. الصورة الذهنية:

تتعدد التعريفات المقدمة لمفهوم الصورة ؛ فالصورة هي الثكل، قال تعالى "الذي خلقك

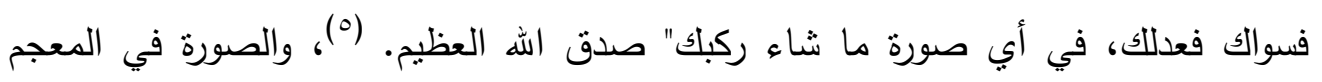
الوجيز تعنى: الثكل. وصورة المسألة أو الأمر: صفتها وكأ والصورة الذهنية: الماهية المجردة، وصورة الثيء: خياله في الأذهان أو العقل (؟). والصورة الذهنية: قد تكون صورة لشيء أو لشخص في ذهن الشهان إنسان ما.. أي فكرته التي كونها عن ذلك الثخص وصورته التي رسمها في ذهنه أي انطباعه عنه( (v). ويعرف قاموس ويبستر الصورة الذهنية بأنها التقديم العقلي لأي شئ أطياعه لا يمكن تقديمه 
للحواس بشكل مباشر ، أو محاكاة لتجربة حسية ارتبطت بعواطف معينة، أو تخيل لها أدركته

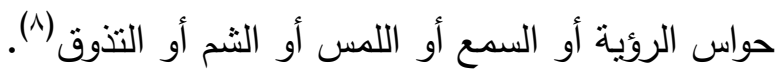

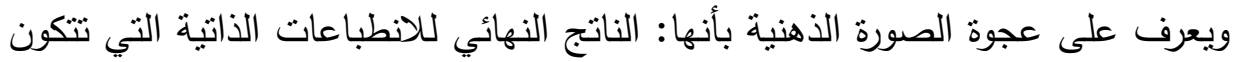

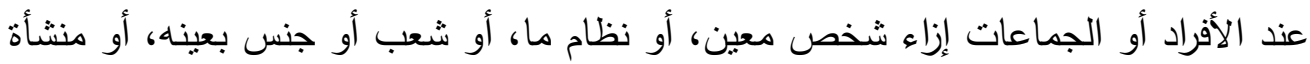

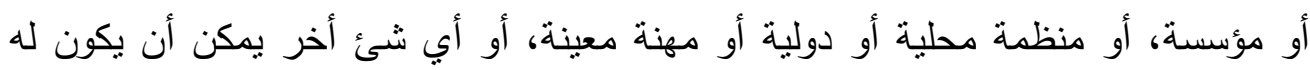

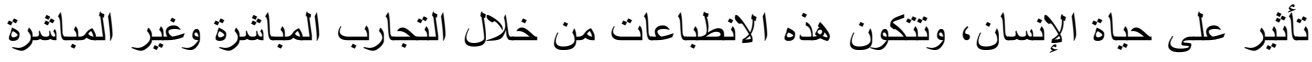

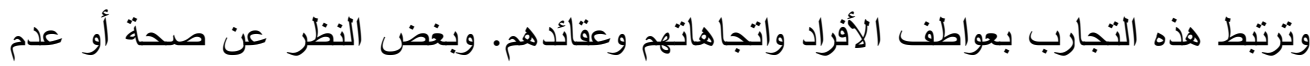

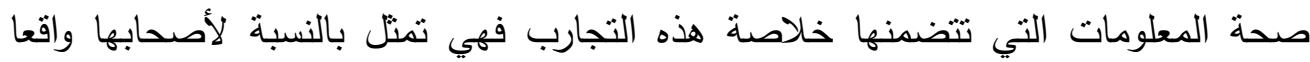

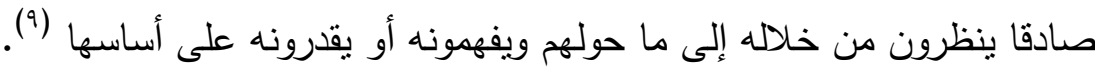
والصورة الذهنية شغلت أذهان الكثير من العلماء والباحثين عن كيفية تكوينها وعملية تكوين الصورة تقوم على تفاعل كل ما يحتفظ به الفرد من معارف ومعلومات وخبرات

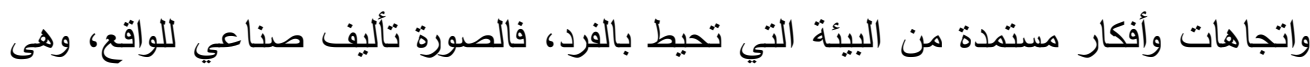

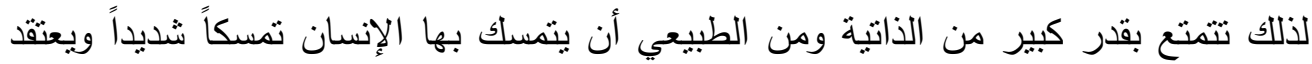
في صحتها وبدافع عنها وتصبح جزءا من ثقافته وتكوينه العقلي والعاطفي فيما بعد (·').

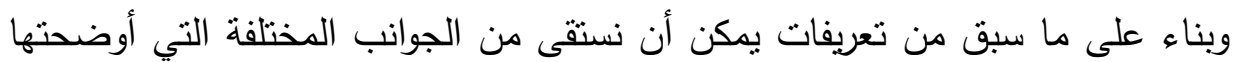

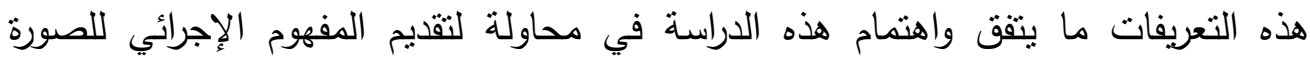
الذهنية بأنها: انطباع ذهني لدى فرد أو جماعة نحو فرد معين أو جماعة معينة أو نظام

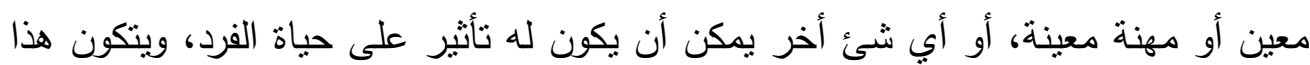

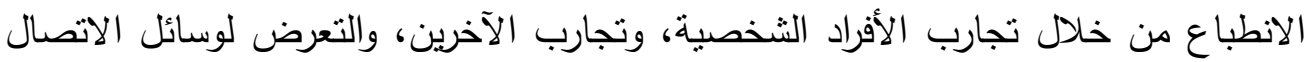
الجماهيرية ومصادر أخرى منل التعليم والدين والعادات والقيم. الإدئ.

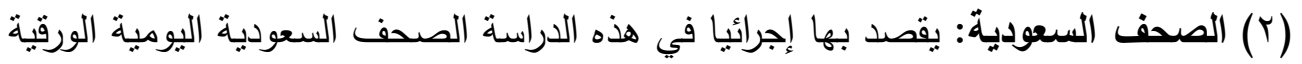
التي تصدر وتوزع بالمجتمع السعودي، وتضم هذه الصحف (الرياض - المدينة - عكاظ-

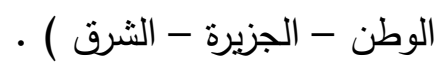

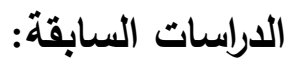
رصد الباحث عدة أبحاث ودراسات تقترب من موضوع الدراسة الحالية، وقد تميزت هذه

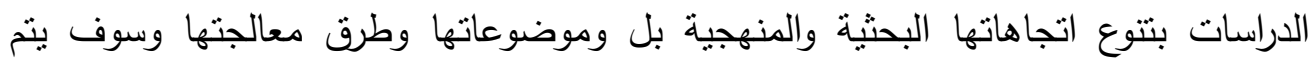
عرضها وفقا للنسلسل الزمني لها من الأقدم إلى الأحدث علي النهات النحو التالي:-

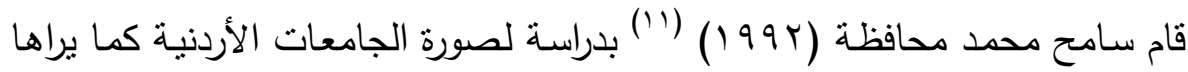
رجال الصحافة والإعـلام الأردنيون، استهدفت معرفة الصورة الذهنية التي يراهـا الصحفيون 
والإعلاميـون الأردنيـون للجامعـات الأردنيـة فيمـا يتعلق بإسـهامها في الميـادين المختلفـة ،

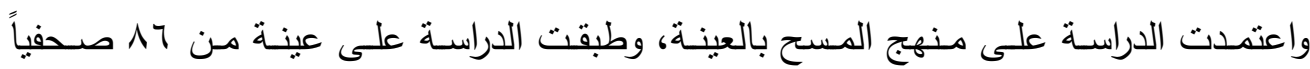

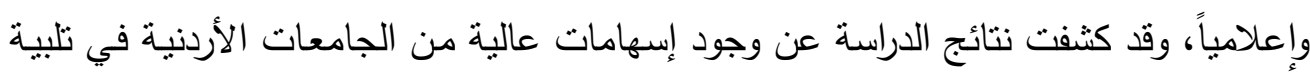

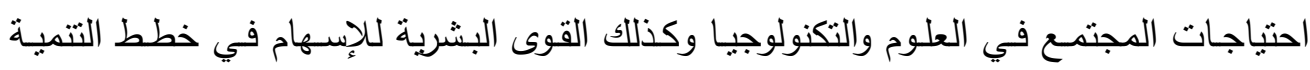
الاقتصادية والاجتماعية. إسهام متدني للجامعات الأردنية في مجال البحث العلمي التطبيقي ومجال تتمية الثعور بالولاء للوطن والتحلي بروح المسؤولية ومجال تتمية الاستقلال الفكري

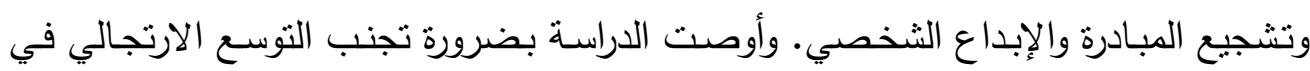

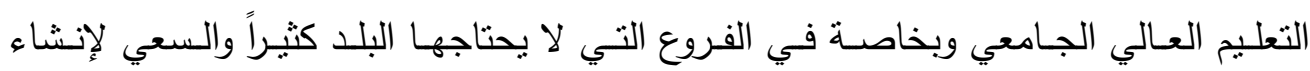
جامعات نوعية في المستقبل. وحاول هارلود ومارجو (ب (999) (r) دراسة سمات الصورة الجانبية للمعلمين في الأفلام والتي هدفت لمعرفة ملامح الصورة الجانبية للمعلمين في الفيلم التجاري والتعرف علي السمات الإيجابيـة والسلبية للمعلمين من خـلال تحليل مضمون الأفكار الرئيسية لعينـة الأفلام، وقد فئد توصلت نتائج الدراسة إلي: ظهور المعلم في صورة مثالية من ناحية نشاطه وكفاحه في بداية الإنها

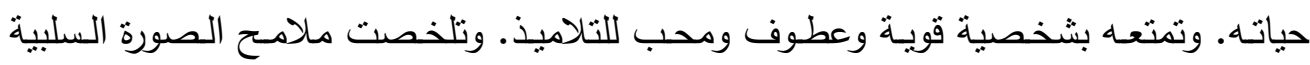
للمعلم في ظهوره كمهرج وغير كفه في عمله. وقد أكدت الدراسة أن الفيلم وسيلة هامة لنقل

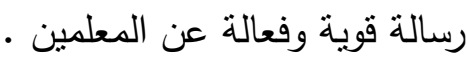
وحرصت دراسـة تشارلز تيليور (991 (1) (') على تحديد ملامسح صسورة الرئيس كيندي لدي طلاب المدارس وفي التقافة الثعبية، من خلال تحليل الصورة التي ظهر بها في الإعلام الحديث وتأثثر هذه الصورة علي طلبة المدارس وقد اعتمدت الدراسـة علي تحليل مضدون مجموعة من البرامج التليفزيونية بالإضـافة لعينـة من الصحف، وكذللك تحليل بعض الصور التي ظهر بها الرئيس كيندي وعائلته، وبعض الكتب التي كتبت عن حياته، بالإضـافة لمسح

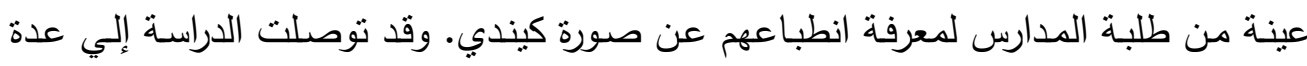

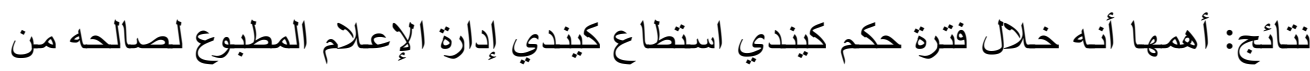

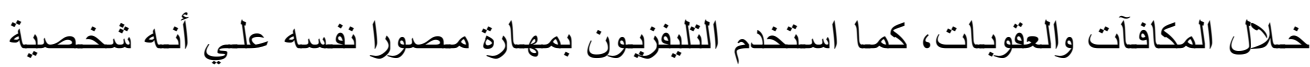
بطولية متزنة محبوبة وذكية. أسهم الذكاء الإعلامي لجون كيندي في إثارة عاطفة الجمهور .

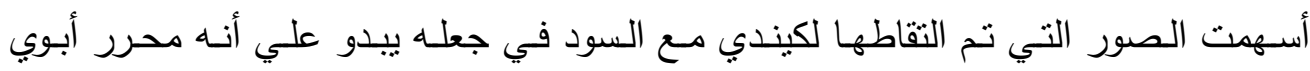
للأمريكان من أصل إفريقي • 


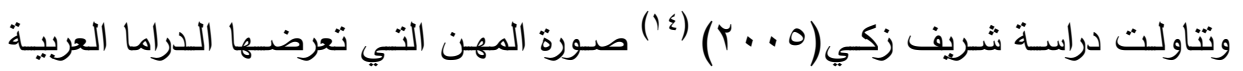

بالتليفزيون وعلاقتها باتجاهات عينة من المراهقين نحو المهن، واستخدم الباحث منهج المسح بشقيه الوصفي والتحليلي. وتوصلت الدراسـة إلي: أن أكثر المهن ظهوراً ( طبيب - رجل التهن

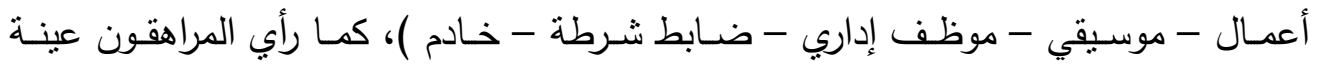

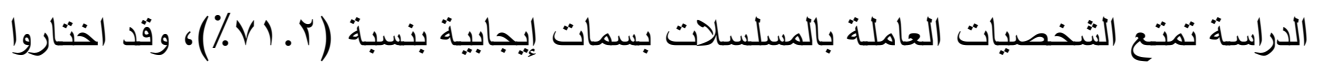

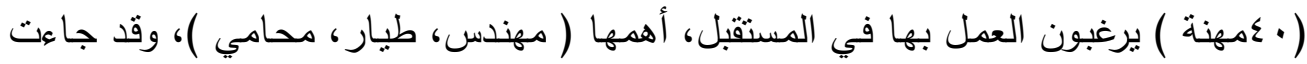
المسلسلات في المرنبة الثانية بنسبة (ع.با ٪ ٪) من حيث المصادر التي يحصل من خلالها المراهقون علي معلومات عن المهن • وركزت دراسة شريفة رحمة الله سليمان (T · . r) (10) على دور العلاقات

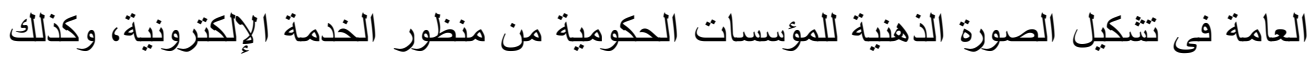
معرفة واقع العلاقات العامة بالمنظمات الحكومية والتطور التكنولوجى فى أساليب الأتصال. وأجرت الباحثة دراسة ميدانية وتحليلية من خلال تحليل مضمون مواقع المؤسسات الحكومية

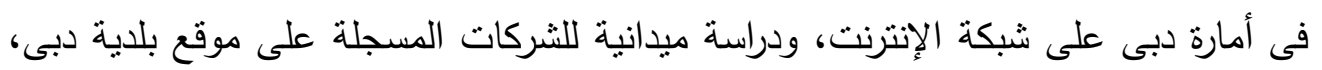

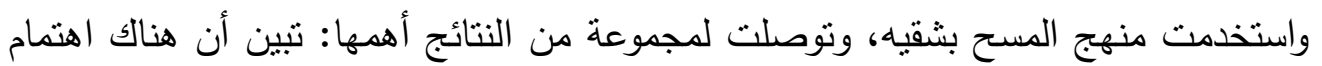

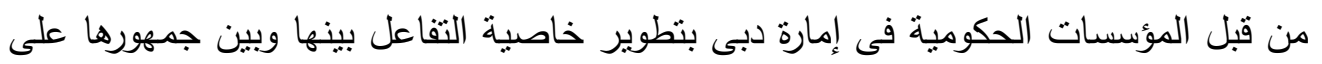
ضوء مفهوم الحكومة الإككترونية. أظهرت النتائج أن الدور الذى يقوم به ممارسو العلاقات

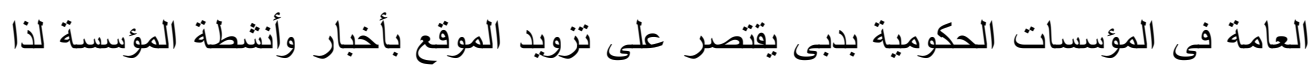

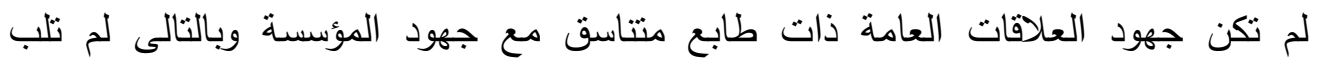

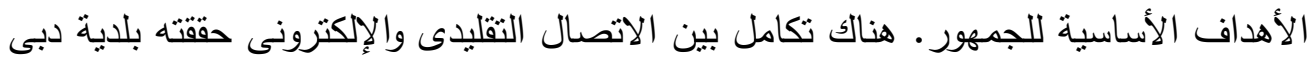
حيث أظهرت النتائج وجود تقارب فى مستويات الرضا بين الوسيلتين الاتصاليتين واستخدام فراد العينة لكافة وسائل الاتصال التى توفرها بلدية دبى.

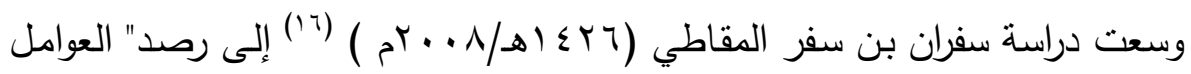

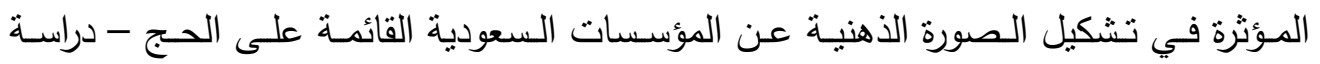

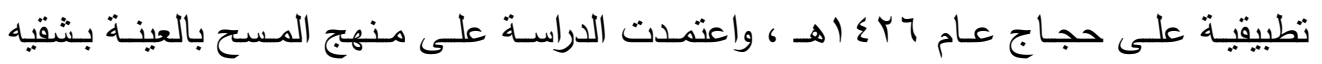

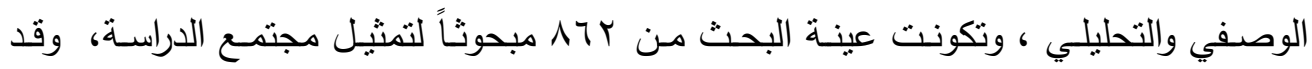
كشفت نتائج الدراسـة عن : وجـود فروق ذات دلالـة إحصائية بين الحجـاج حسب جنسهر

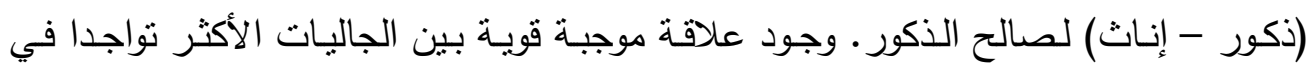


المملكة ونسب أعدادهم في المؤدين للفريضة. كان تقييم عينـة الدراسـة إيجابي حول معظم الخدمات المقدمة بما يعكس مستوى الرضا لديهم.

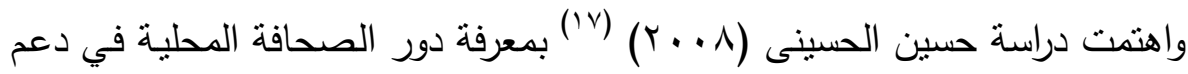
الصورة الذهنية للمؤسسات التشريعية لدى الجمهور : من خـل دراسة تطبيقية على مجلسي دهي

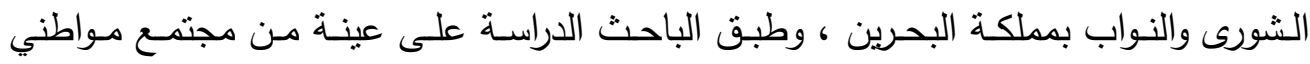

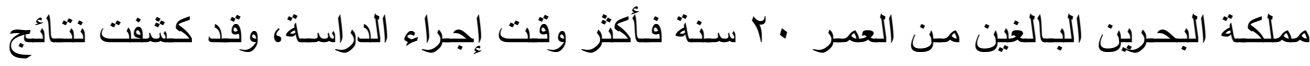

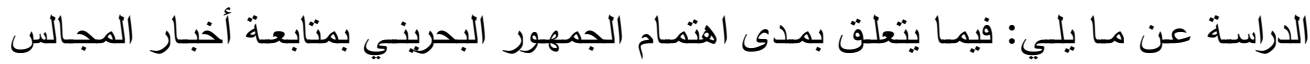

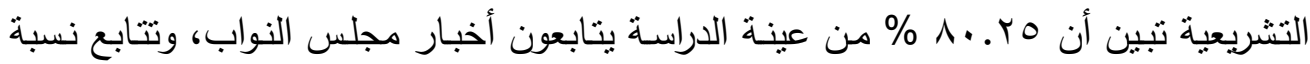
\%^v.. تقوم بدور بارز في دعم الصورة الذهنية للمجالس التشريعية بدولة البحرين.

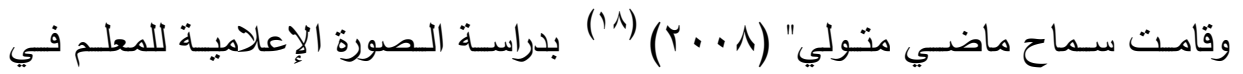
الصحف المصرية وعلاقتها بتكوين الاتجاهات لدي عينة من المراهقين والمعلمين نحو المعلم، حيث هدفت الدراسة إلي التعرف علي سمات الصورة التي تقدمها الصحف للمعلم المصري مدري ومدي مساهمة الصحف في خلق وتكوين صسورة عن المعلم ، استخدمت الدراسـة منهج المسح، وتكونت العينة من . ـ مفردة بمحافظة الجيزة ، واستخدمت استمارة استبيان ومقياس

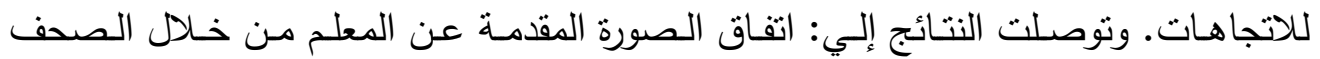

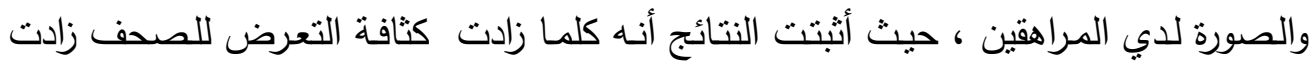

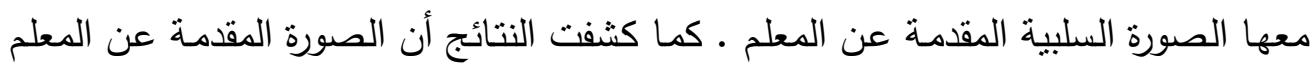

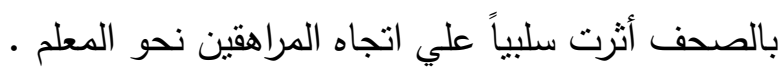

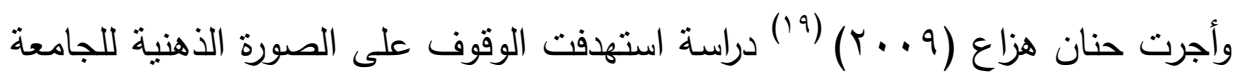

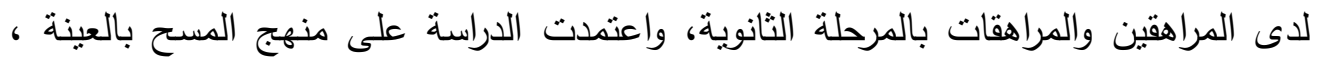
وتكونت العينة من و ج مفردة من المراهقين والمراهقات من طلبة الصفين الثاني والثالث الثانوي العام في المدارس الحكومية والخاصة ومن القسمين العلمي والأدبي ببعض الإدارات التعليمية بمحافظة القاهرة، وقد كثفت نتائج الدراسة أن الصورة الذهنية للجامعة لدى طلاب المرحلة الثانوية تختلف باختلاف النوع (ذكور - إناث)، ونوع التعليم (عام - خاص)، 
والمستويات الاجتماعية والاقتصادية المختلفة للمراهقين (المنخفض - المتوسط - المرتفع) بالنسبة للصورة الذهنية للجامعة لديهم.

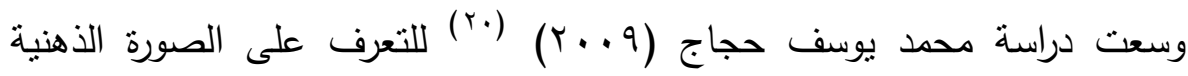
المدركة لبعض المظاهر السلبية للأستاذ الجامعي بغرض التعرف على هذه السلبيات ومحاولة

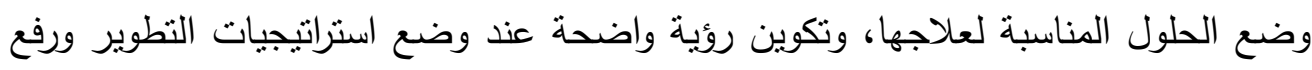
جودة أداء الأستاذ الجامعي بكليات التربية البدنية والرياضة. واعتمدت الدراسة على الى المنهج

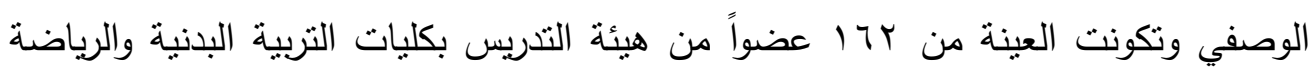

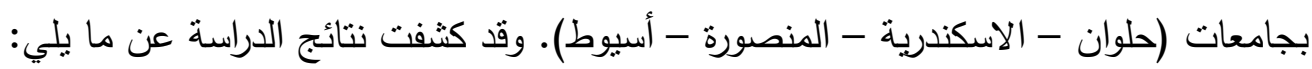

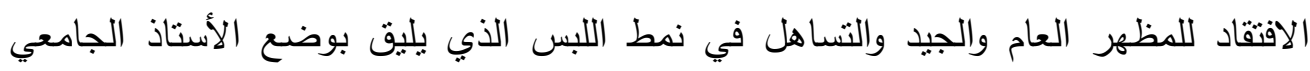
بكليات التربية البدنية والرياضية. الجانب الأخلاقي لدى بعض أعضاء هيئة التدريس بكليات

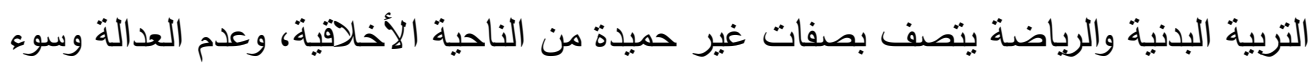
استخدام السلطة واستغلال النفوذ، والسلوك اللفظي غير الملائم. طغيان القيم المادية والبحث

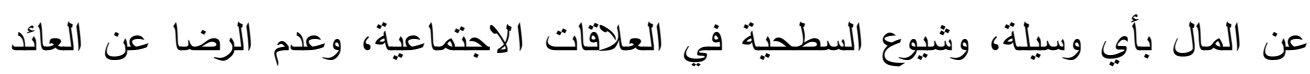
والدخل المادي لمهنة عضو هيئة التدريس بكليات التربية البدنية والرياضة.

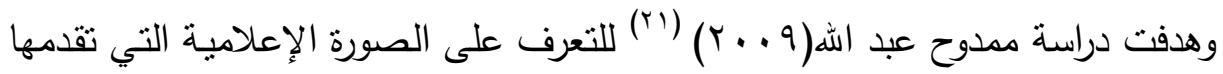
القنوات الفضائية للحكومة المصرية وعلاقتها بالصورة الذهنية التي يكونها جمهور الشباب في

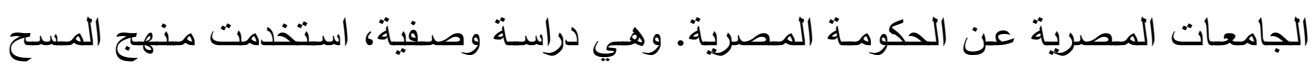
بالعينة بشقية التحليلي والميداني، وقد أظهرت نتائج الدراسة التحليلية أن طبيعة الصورة التي وركية

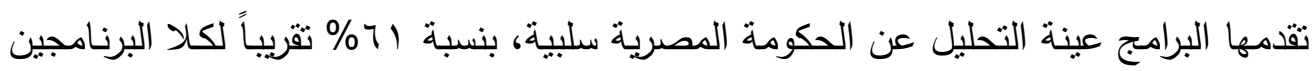

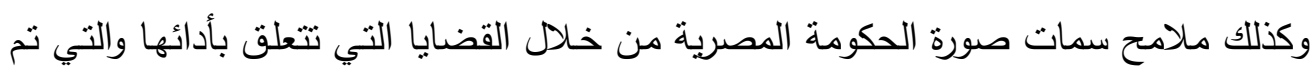

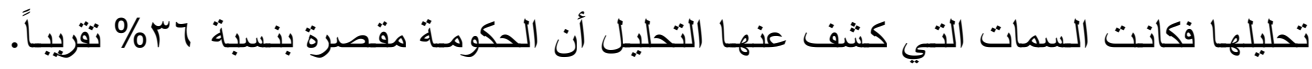
وفيما يتعلق بالدراسة الميدانية فقد جاءت الصورة الذهنية للحكومة المصرية صورة سلبية لدى لدى

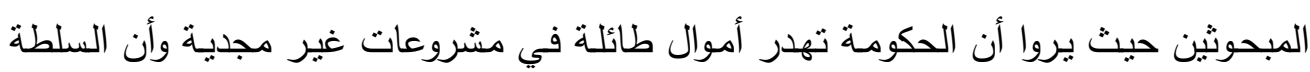
يجب أن تكون متداولة وليست حكراً على حزب بعينة.

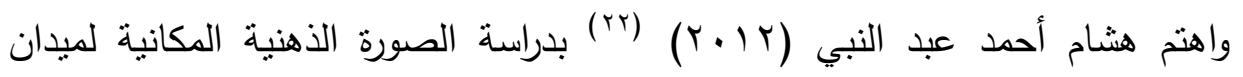

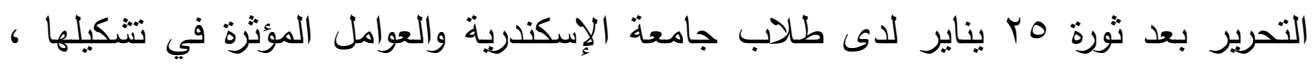
واعتمدت الدراسة على المنهج الوصفي وجمعت بين التحليل الكمي والكيفي في دراسة الصور 
الذهنية المكانية لدى الطلاب، وكثفت نتائج الدراسة عن: وجود فروق ذات دلالة إحصائية ترجع إلى نوع التخصص الأكاديمي والذي يعد عامل مؤثر في تثكيل الصورة الذهنية المكانية

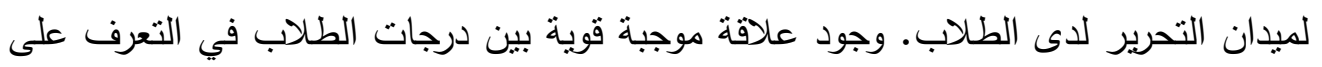

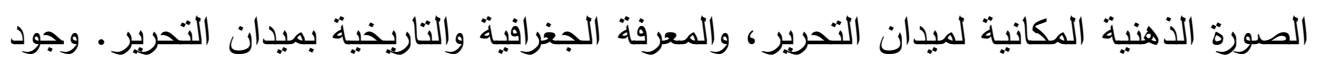
فروق ذات دلالة إحصائية بين الطلاب حسب النوع (ذكور - إناث) في اختبار التعرف على لئى

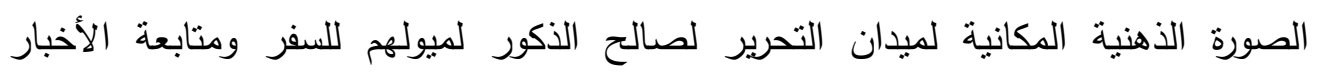

$$
\text { والاتترنت عن الإناث. }
$$

\section{تعقيب على الاراسات السابقة :}

- أوضحت نتائج الدراسات السابقة أن الصورة الذهنية للجامعة لدى طلاب المرحلة الثانوية تختلف باختلاف النوع (ذكور - إناث)، ونوع التعليم (عام - خاص)، والمستويات

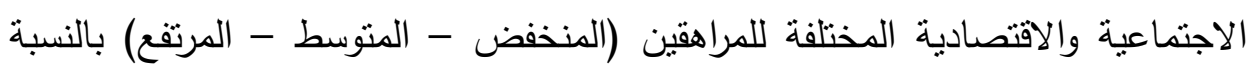

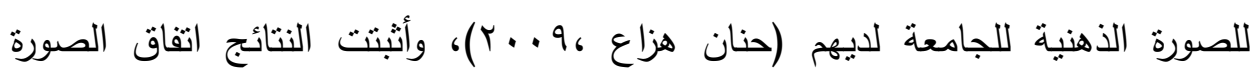

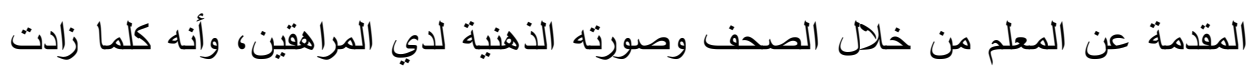
كثافة التعرض للصحف زادت معها الصورة السلبية المقدمة عن المعلم ـ كما كثنفت النتائج أن الصورة المقدمة عن المعلم بالصحف أثرت سلبياً علي اتجاه المراهقين نحو

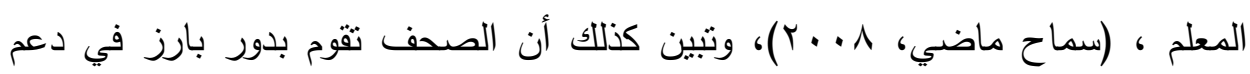

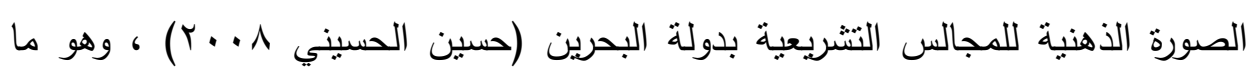

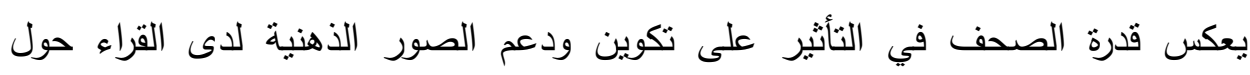

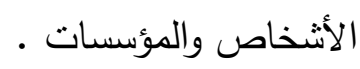
- تمكن الرئيس الأمريكي كيندي من إدارة الإعلام المطبوع لصالحه من خلال المكافآت

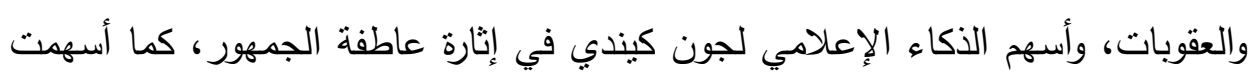

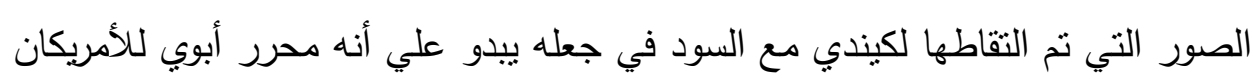

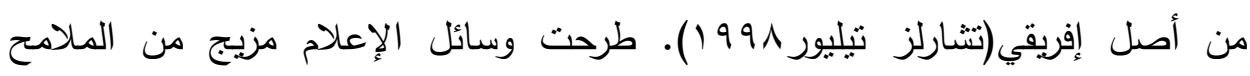
الإيجابية والسلبية في الصور الذهنية عن الثخصيات والمؤسسات حيث أظهرت الأفلام

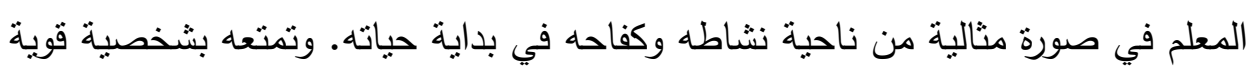
وعطوف ومحب للتلاميذ. كما عرضت العديد من ملامح الصورة السلبية للمعلم في نئيل ظهوره كمهرج وغير كفء في عمله. وقد أكدت الدراسة أن الفيلم وسيلة هامة لنقل رسالة 
قوية وفعالة عن المعلمين (هارلود ومارجو ب99 ()).

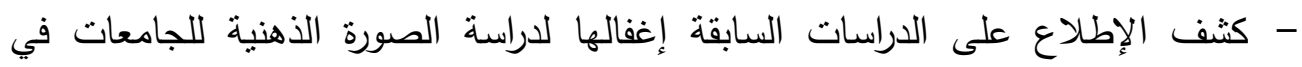
الصحف وعلاقتها بصورتها الذهنية لاى العاملين بها، فلم تهتم أي من الدراسات السابقة

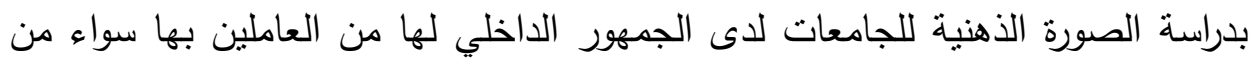
أعضاء هيئة التذريس أو الموظفين، وكذلك لم تسعي تلك الدراسات للوقوف على الملامح

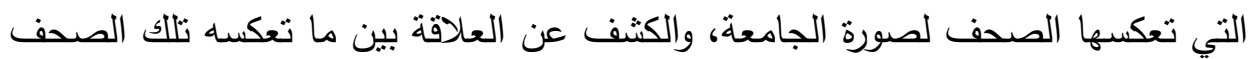
من ملامح لصورة الجامعة وبين ما يدركه العاملين بها من تللك الملامح ، وخلت كافة

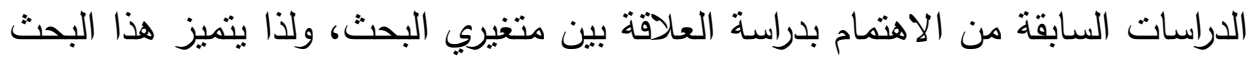
عن الدراسات السابقة بمحاولة التوصل لطبيعة واتجاه العلاقة بين الصورة الذهنية لجامعة تبوك في الصحف السعودية وعلاقتها بصورتها الذهنية لدى العاملين بها.

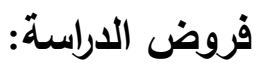

في ضوء ما استعرضه الباحث من نتائج للدراسات السابقة، فإن الدراسة الحالية تسعى إلى اختبار صحة الفروض التالية: الفرض الأول:

توجد علاقة دالة إحصائيا بين تعرض المبحوثين لأخبار الجامعة بالصحف السعودية وإدراكهم لملامح الصورة الذهنية التي تعكسها هذه الصحف عن الجامعة:-

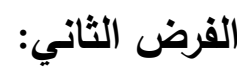
" نوجد علاقة ارتباط إيجابي دالة إحصائيا بين معدل تعرض المبحوثين لأخبار الجامعة بالصحف وكل من : م إدراك العاملين بالجامعة لواقعية الصورة المقدمة بالصحف عن الجامعة . O تقييم العاملين بالجامعة لأدائها . الفرض الثالث: - (الث:

توجد فروق ذات دلالة إحصائية بين متوسطات درجات المبحوثين على الدرجة الكلية

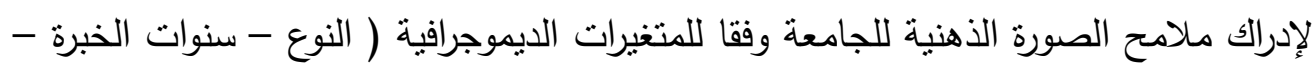

$$
\begin{aligned}
& \text { المؤهل التعليمي - نوع المهنة ). } \\
& \text { الإطار المعرفي : }
\end{aligned}
$$




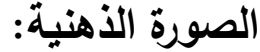

اهتمت العديد من الدراسات الإعلامية بدراسة صورة المنظمات والثركات والمؤسسات المختلفة للتعرف على نظرة الجماهير لهذه المنظمات ومعرفة الجوانب الإيجابية والسلبية في

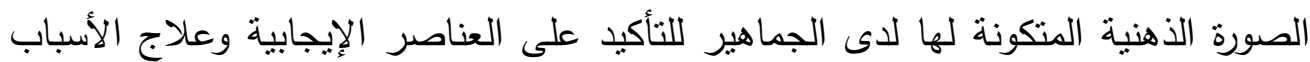

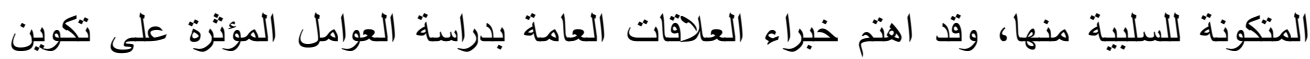

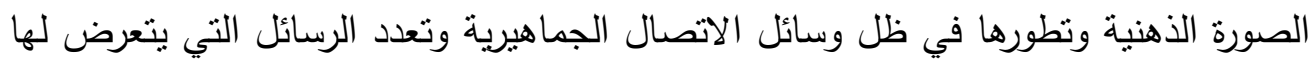

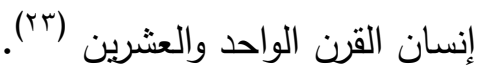

ونظرا لأهمية الصورة الذهنية للفرد والمنظمة وما تقوم به من دور هام في تكوين الآراء

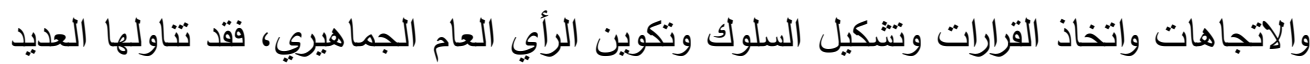

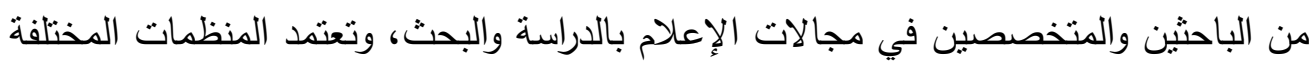

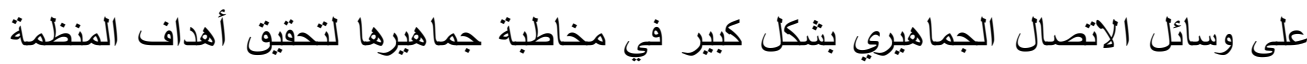
وتكوين صورة ذهنية طيبة من خلال ما تقدمه من خدمات في أذهان الجماهير من خلادل

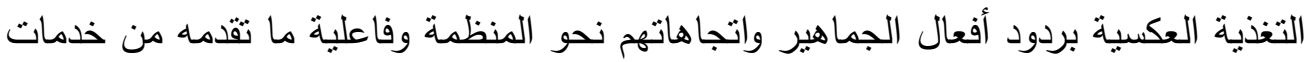

فقد أصبح للمنظمات الحديثة مسئولية كبيرة في نتكيل وتدعبم الصورة الذهنية الطيبة

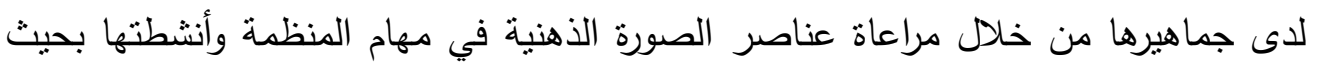
يكون تركيب هذه العناصر بشكل موحد يقدم المنظمة إلى الجماهير بشكل يحقق لهام الها الهيبة والمكانة (ro)

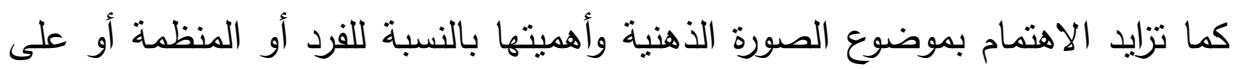
مستوى الدول نظراً لما تقوم به هذه الصورة من دور هام في تكوين الآراء واتخاذ القرارات

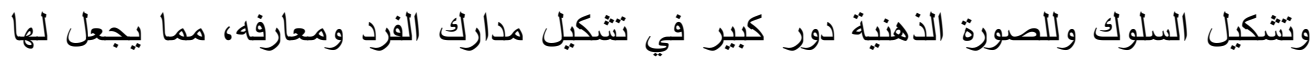
تأثثراً واضحاً على سلوك الفرد وقدراته وتوقعاته وردود أفعاله إزاء الكثير من القدار القضايا الهامة.

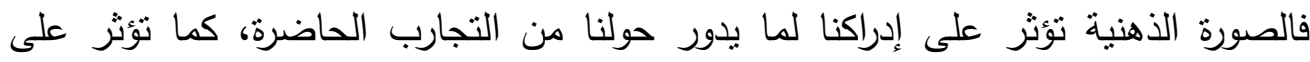

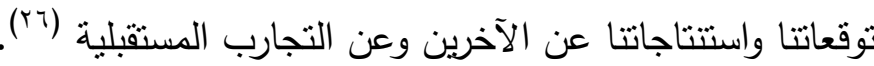
تعريفات الصورة الذهنية:

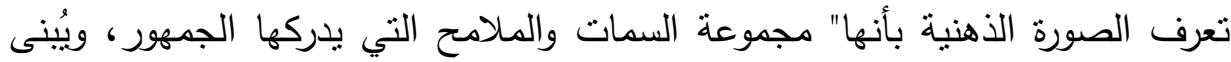

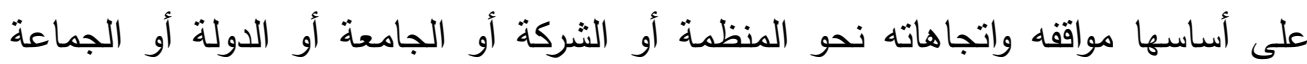

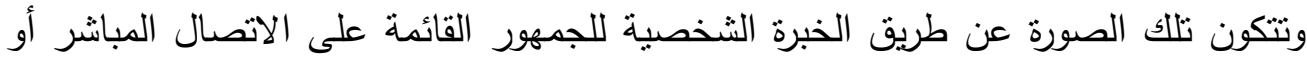
عن طريق العمليات الاتصالية الجماهيرية وتتشكل سمات وملامح الصورة الذهنية من خلال 
إدراك الجمهور لشخصية المنظمة ووظائفها وأهدافها وشرعية وجودها وأعمالها والقيم الأساسية

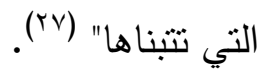

ويرى آخرون بأن الصورة الذهنية هي "الصورة الفعلية التي تتكون في أذهان الناس عن النهان

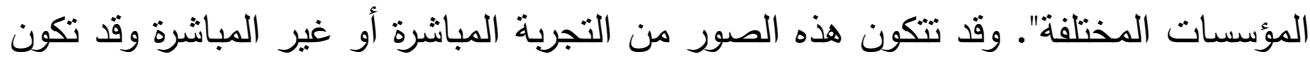

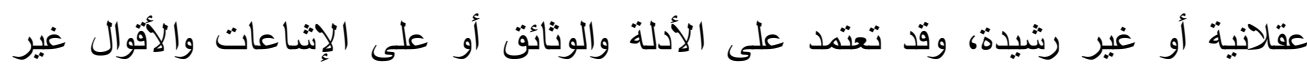

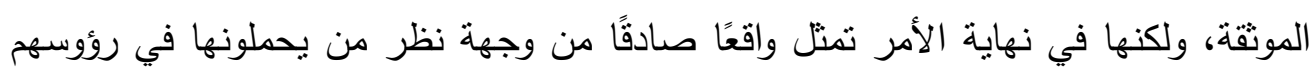

والصورة الذهنية في قاموس لونجمان هي "الصورة المشكلة في الذهن وهى الرأي العام

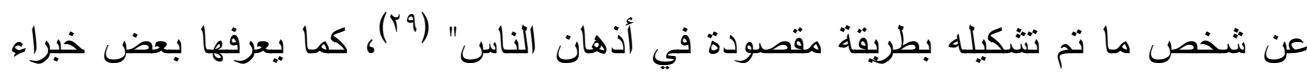

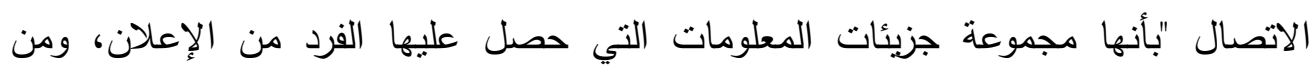

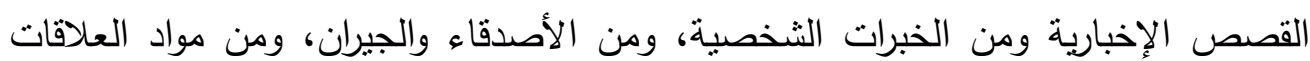

العامة الإعلامية والتي يستخدمها الفرد في بناء واحد ليشكل الصورة الذهنية لديه (·•).

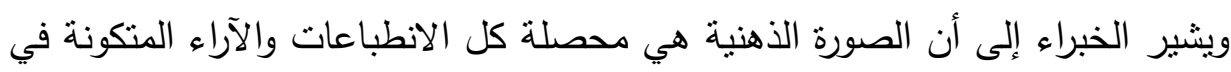

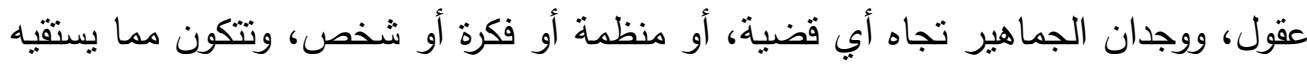

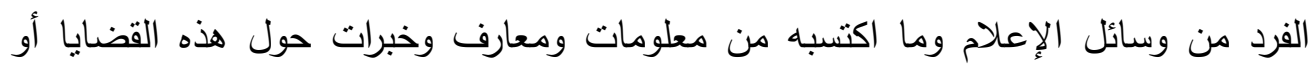
المنظمات أو الأفراد، ولا تتطبع هذه الصورة، وتكتسب مرة واحدة فقط، ولكنها عملية دائمة

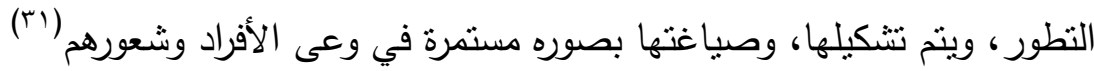

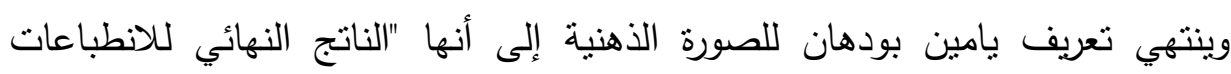

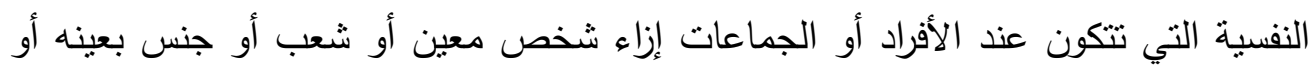

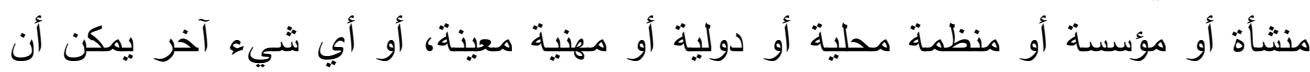

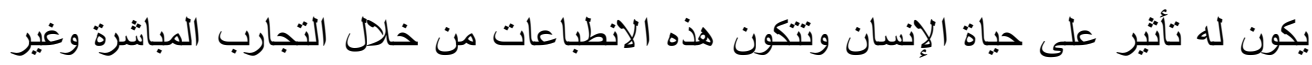

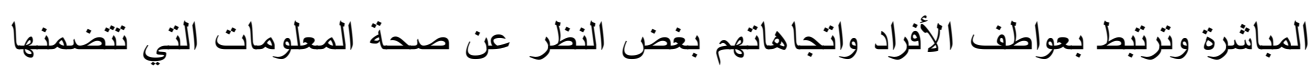

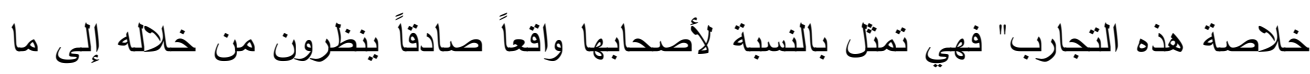
حولهم ويفهمونه ويقدرونه على أساسها (بَّ).

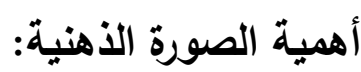

حظى موضوع الصورة الذهنية باهتمام الباحثين في الدراسات الإعلامية والاجتماعية

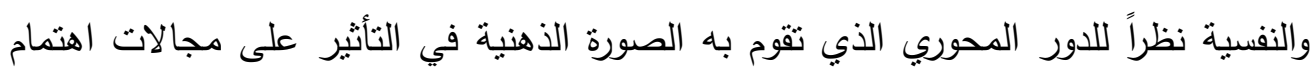

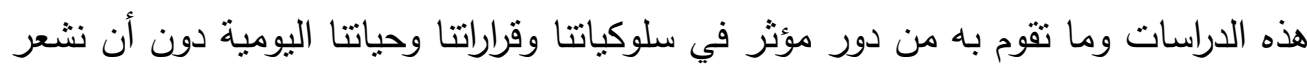

بتأثيراتها شبه المنتظمة في تسيير أمور حباتتا (rr). 
ويتوقع البعض أن يتطور مفهوم الصورة الذهنية في المستقبل القريب ليصبح علم جديد قائم بذاته له أصول وقواعد ونظريات، بسبب ازدياد أهميتها للمنظمات والجماعات العرقية والدينية لتتكيل صورة ذهنية إيجابية، وقد ازداد الاهتمام من قبل علوم العلاقات العامة

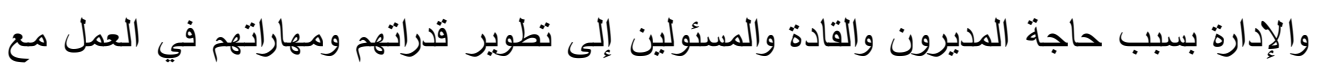

الجمهور للمساهمة في بناء صورة طيبة للمنظمة التي يعملون في إدارتها (عَّ). وتكتسب الصورة الذهنية للمؤسسات أهمبة كبرى في ظل التطورات المعاصرة وتأثنرها

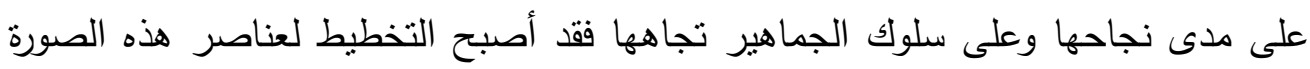
جزء لا يتجزأ من التخطيط الثامل لأنشطة مختلف المنظمات فكما تؤثر جميع النشاطات

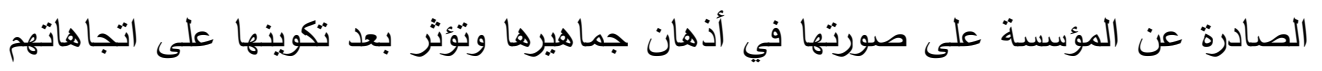
وسلوكياتهم نحو المؤسسة وهو ما ينعكس على جميع أنشطة المؤسسة الداخلية والخارجية التي

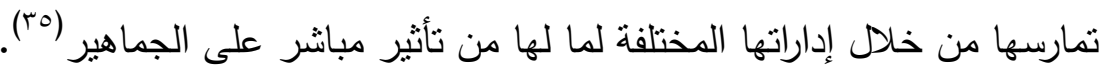
وفي ظل تقدم العلوم الاتصالية المختلفة تعاظم الاهتمام بالصورة الذهنية مع التقدم الكبير في مجالات الاتصالات والمعلومات ومنه ازدياد أهمية دراسة الصورة في مختلف فروع الاعلماله الإعلام في نواحي السياسة والاقتصاد والإدارة والاجتماع (بَّ).

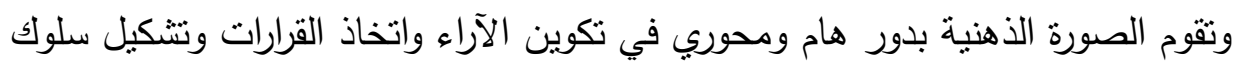

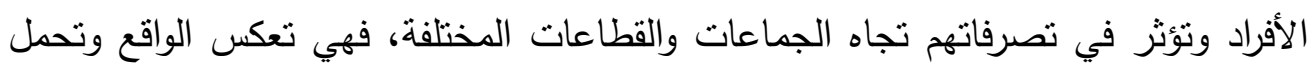

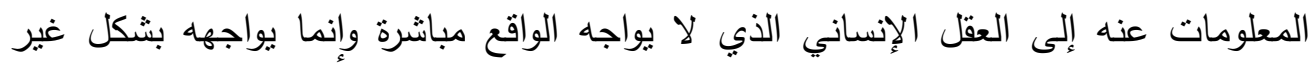

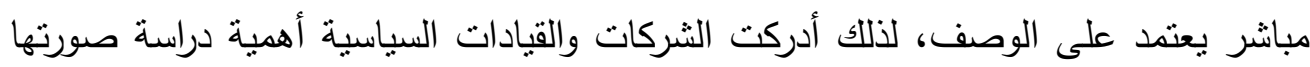

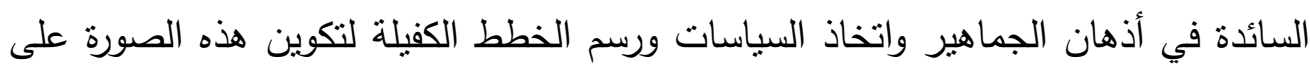
النحو الذي تتمناه هذه الثركات أو تللك القيادات واستخدام ذلك في دعم أنشطتها، وإذا كانت صورتها مضطربة عملت بتركيز شديد على وضع الاستراتيجيات المختلفة لتحسينها وتأكيدها.

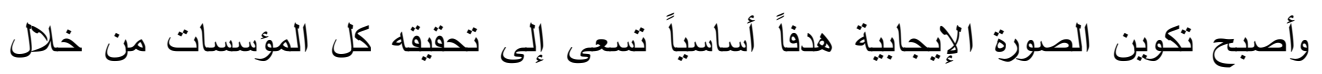
الأداء الطيب الذي يتفق مع احتياجات الجماهير (؟r). ومفاد القول أن أهمية الصورة الذهنية تكمن في انطباعها في أذهان الجماهير الخارجية

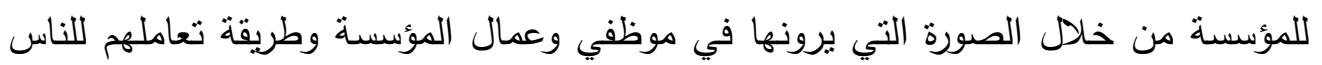
وأدائهم لواجباتهم (广^) 
وتأسيساً على ذلك فإن للصورة الذهنية أهمية وخاصة للأفراد والمنظمات حيث تشكل

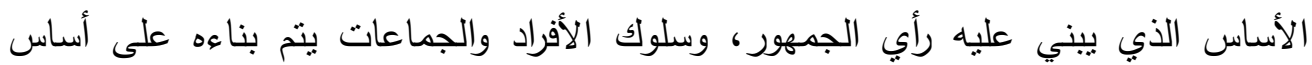

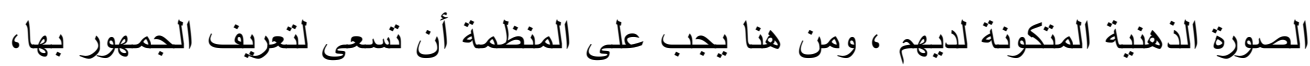

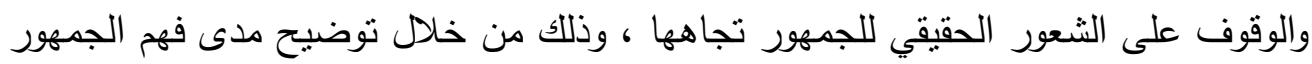

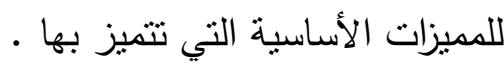
وحول أهمية الصورة الذهنية للأفراد فهي تسهم في تحديد سلوك الفرد الذي يعتمد في

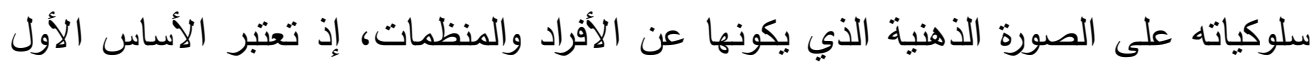

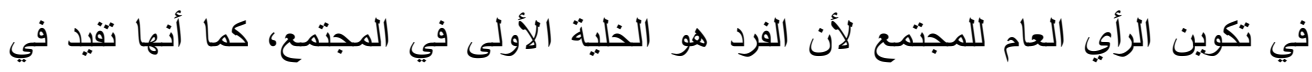
تضييق الفجوة الاجتماعية بين الفرد والمجتمع المحيط، وتعمل على توصل الفئ الفرد إلى أبعاد

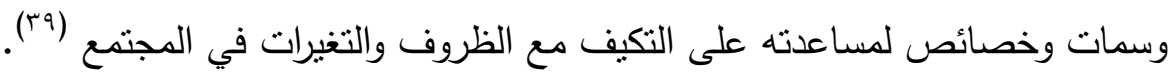

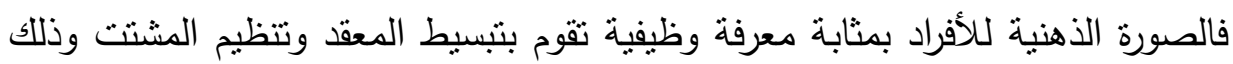

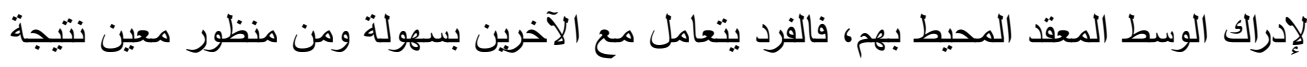

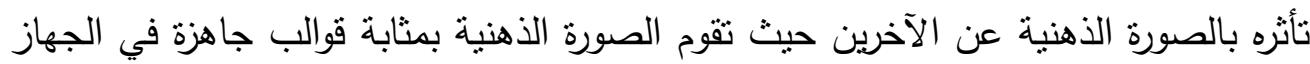

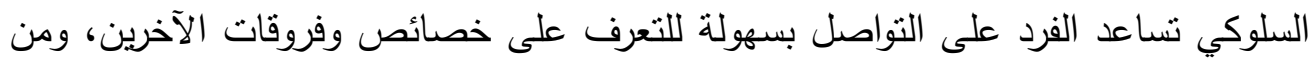

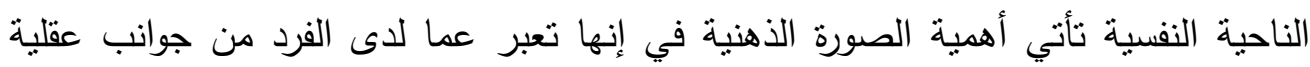

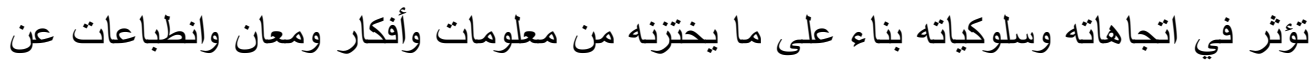

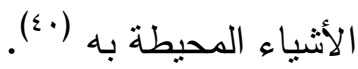
أما بالنسبة لأهمية الصورة الذهنية للمنظمات والمؤسسات فهي تقوم على عكس أداء

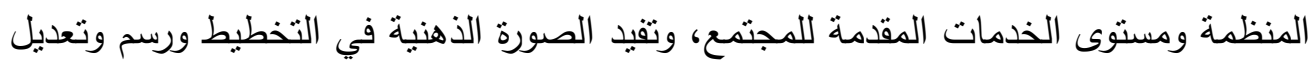

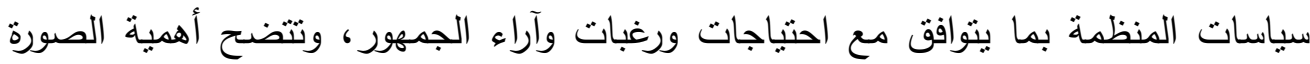

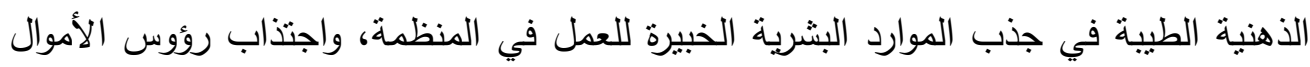
وزيادة المساهمين التي تضمن نمو وتطور المنظمة، كما تساعد الصورة الذهنية في زيادة

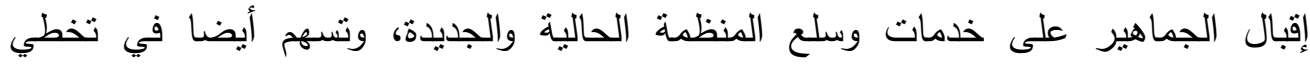

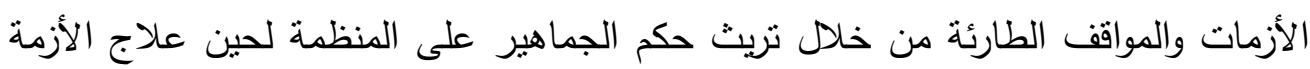

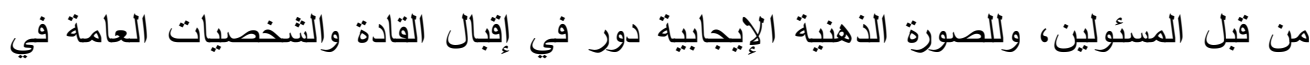

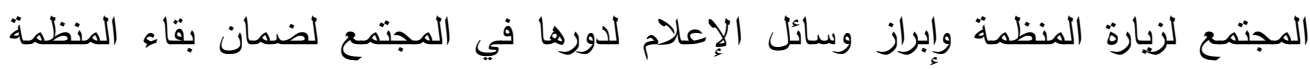

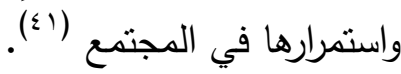
فصورة المؤسسة عبارة عن انعكاس لنخصية المنظمة في أذهان جماهيرها وهي

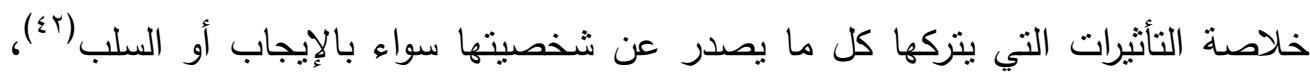


وتقوم العديد من المنظمات والدول بإنفاق الكثير من الأموال وبذل الجهود لتكوين صورة ذهنية إيجابية لأنها من أهم العوامل المساعدة على تحقيق النجاح سواء على المستوى الداخلي أو لأولفي الخارجي للمنظمة، وتقسم المميزات على مستوبين داخلي وخارجي. وعلى المستوى الداخلي فإن زيادة الصورة الذهنية الطيبة ورضا العاملين عن المؤسسة ولهئ يؤدي إلى زيادة الإنتاجية للعاملين داخل المنظمة، حيث تساعد الصورة الطيبة في ارتفاع

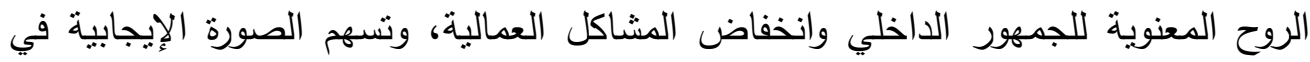
جذب رؤوس الأموال وزيادة أعداد المساهين واجتذاب الموزعين والموردين وإلى تسهيل

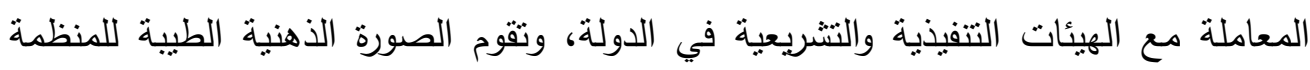
بدور حيوي في ازدياد القرارات الناجحة ورسم الخطط وتحقيق الأهداف . وعلى المستوى الخارجي فإن الصورة الذهنية الطيبة تساعد في ازدياد ثقة الجمهور في منتجات وخدمات المؤسسة، وتمكنها من ازدياد إمكانية تقبل الجمهور لأدائها، وتقوم بدور لهائه

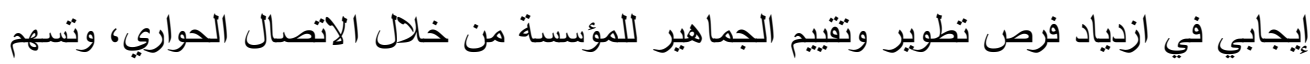
الصورة الذهنية الطيبة في تطوير علاقة المؤسسة بالجماهير من خلال المشاركة المنبادلة الفعالة في الأنشطة والفعاليات حيث تساعد على تقليل إمكانية حدوث ردود فعل عدائية من بن بن

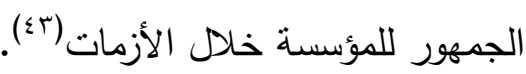
ومن المميزات الأخرى للصورة الذهنية اجتذاب الكوادر البشرية ذوي الكفاءة العالية

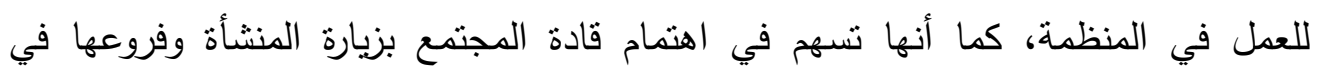

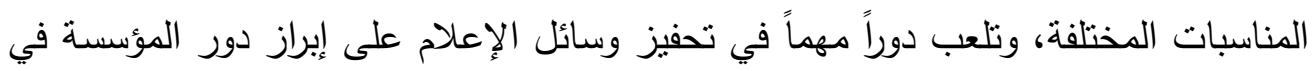

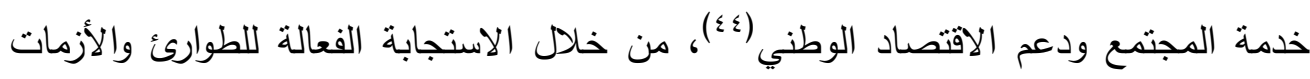

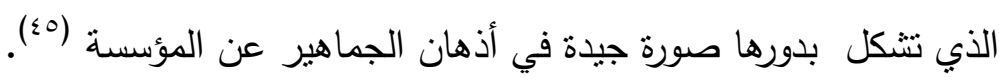

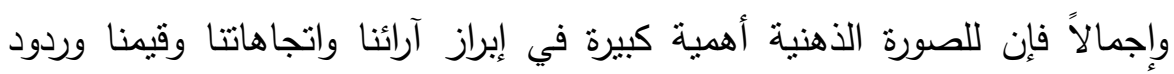

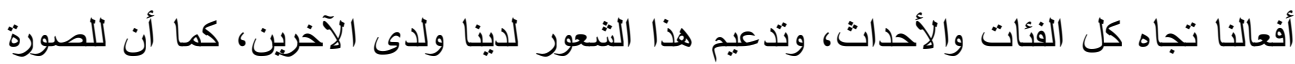
الذهنية دوراً بارزاً في حياة الأفراد، فأنها تقوم أيضا بدور في غاية الهان الأهمية في حياة الدول والشركات والمؤسسات، الأمر الذي يبرر حرص هذه الأطراف كافة على أن تكون صورتها

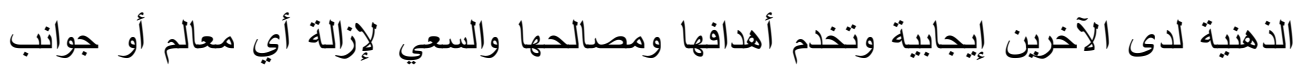
سلبية موجودة في هذه الصورة أو قد نطرأ عليها(َ؟). 


\section{دور وسائل الإعلام في تثكيل الصورة الذهنية:}

أثنار العديد من الباحثين إلى أن الصورة الذهنية تتأثر بعدة عوامل منها ما يتعلق

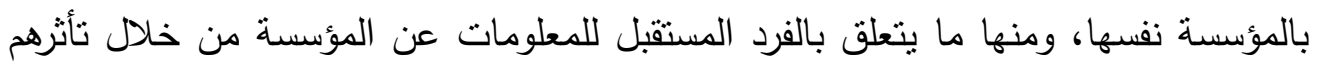

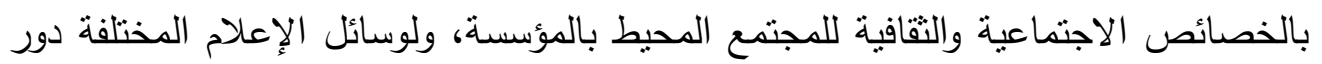
في التأثنر على الرأي العام وتغيير الصورة السيئة للمنظمة أو المؤسسة وتبديلها بصورة ذهنية بالئه طيبة من خلال الموضوعية في نشر المعلومات والأخبار عن المؤسسة. كما يعتبر تاريخ المنظمة أو المؤسسة وقوتها واستقرارها وإنجازاتها الجيدة ونجاح ونساح سياساتها وخططها ونهوضها بمسئولياتها الاجتماعية وسمعتها الطيبة كمؤسسة من أهم ما

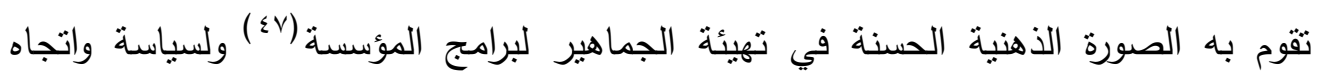
المنظمة والعاملين بها والتطورات والتحسينات في الخدمات ومدى الاستجابة للتغيرات

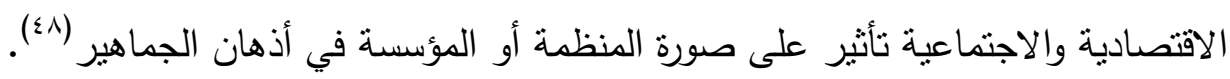
فالاتصال بالجماهير من خلال وسائل الإعلام يزيد من مصداقية المنظمة والثقة فيها

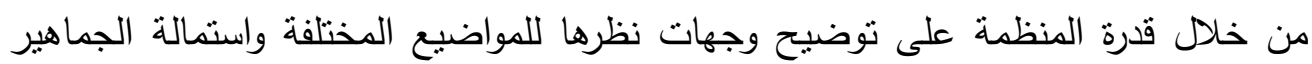
لجانبها(9)، ولوسائل الإعلام فعالية كبيرة في تزويد المناصرين من الجماهير لفكرة ما بالآراء التي تعزز الاختلاف والتبرير الذي تحتاجه الجماهير للحفاظ على مواقفهم، ولوسائل الإعلام

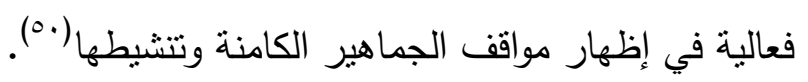

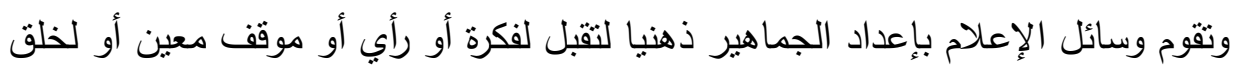

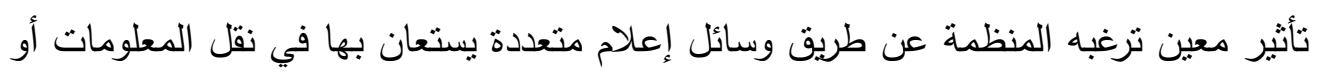

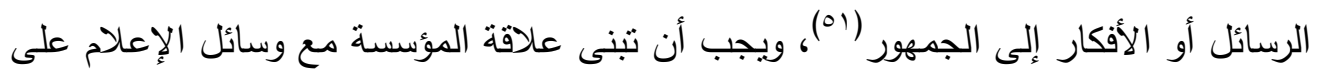

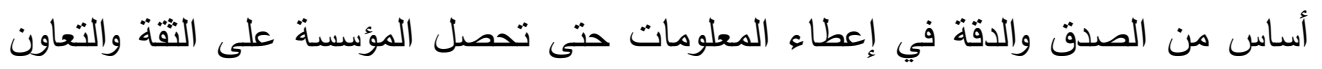

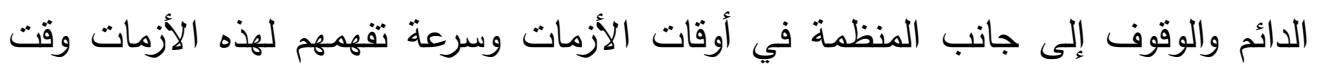

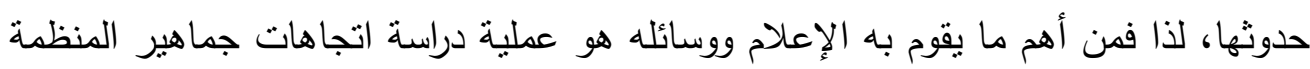
وتتسيق جهود إداراتها لأجل تحسين صورة المنظمة وتاريخها في أذهان الجماهير (كمان.

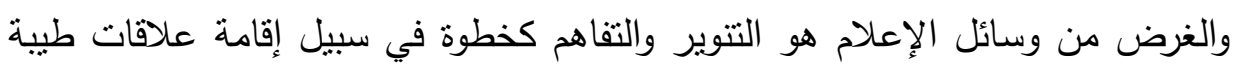
بين المؤسسة وجماهيرها وتقديم خدمات جليلة للمؤسسات والهيئات وكسب تأيبيد الرأي العام من خلال التعاون المشترك في حل المشكلات لإصدار التشريعات والقوانين الملائمة (Or) . 
وتقوم وسائل الإعلام بنشر الأخبار والمعلومات الدقيقة المبنية على الصدق والصراحة من خلا مخاطبة الجماهير باستخدام الوسائط والوسائل المختلفة التي ينتوع تأثيرها في والئي

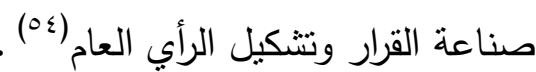
ويأتي ذلك في سياق سعيها لتحقيق أهدافها ومهامها، من خلال تقديم المعرفة للأفراد

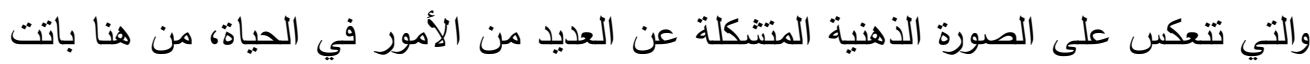

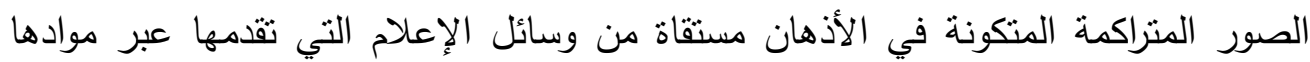

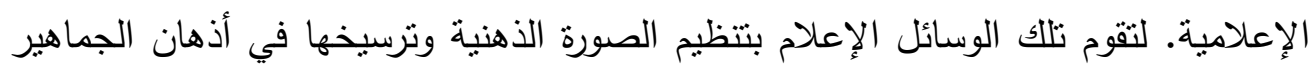

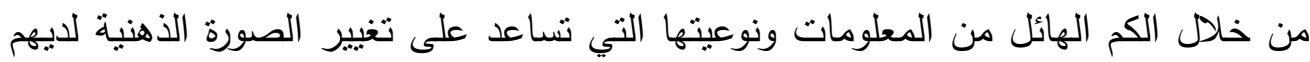
عن طريق التأثير في المستوى المعرفي بشكل خاص، عندما يتقق مضمون الرسائل الإعلامية

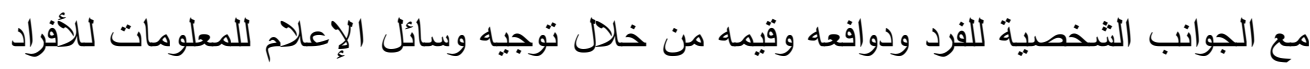
والذي يعتبر من أهم الطرق المؤثرة في تكوين الصورة الذهنية (00). وبذلك تؤدي وسائل الإعلام دور مهم في تثكيل الصورة الذهنية للجماهير عن فئن المنظمات والهيئات والدول حيث تعتبر نافذة الأحداث والقضايا وأنشطة المؤسسات المختلفة، دورة

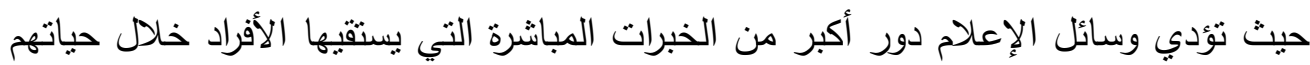
اليومية (107).

ويتبين أن وسائل الإعلام الجماهيرية المعاصرة تلعب دورا أساسيا على مستوى ردود

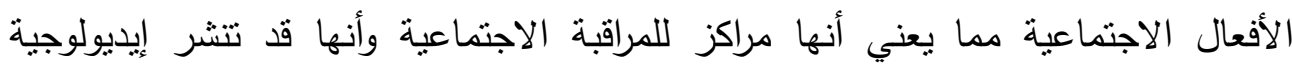
مهيمنة هي نفسها التي نجدها في المدرسة الأسرة، في المحتوى الإعلامي، وتقوم وسائل

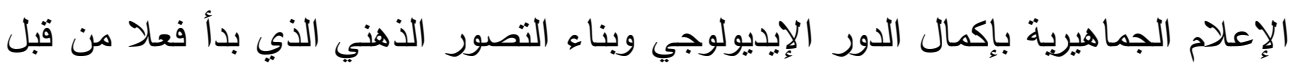
المؤسسات التقليدية في الأسرة والمدرسة وهذا الأمر يدعم بقوة التتوع الذي تحاول الإنياء أن تبديه

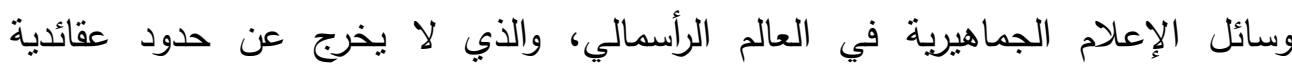
معينة)(ov).

وتؤثر الصورة الذهنية بشكل مباشر على مخيلة الجماهير وكلما ازدادت الصورة قوة كلما سهل استقطاب الجماهير والتأثثر عليهه، وتمنلاك وسائل الإعلام قدرة التأثير على الجماهير الثير عبر آليات وأساليب تحرك الجماهير وتصبغ الرأي العام حيث تقوم بصياغة الواقع الاجتماعي ولئي والاقتصادي والسياسي للجمهور وقد تصنع في بعض الأحيان من خلال نوظيف الصورة الذهنية كمحرك أساسي واقعا غير دقيق ومشوه (م) . . 


\section{الصحف وتثكيل الصورة الذهنية:}

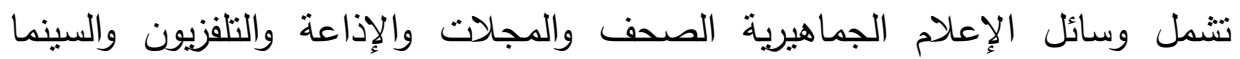

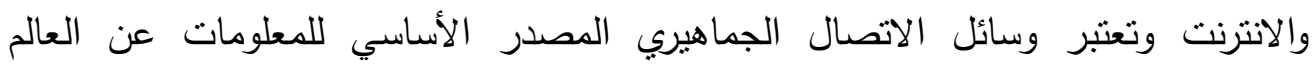

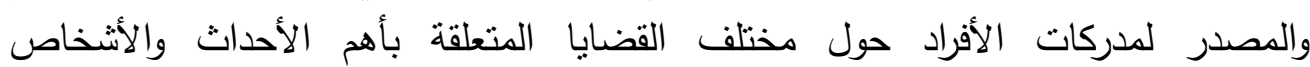

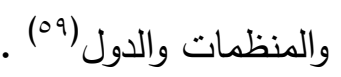

ولهذه الوسائل أهمية باعتبارها أدوات مساعدة في بناء سمعة وصورة المنظمة من خلال

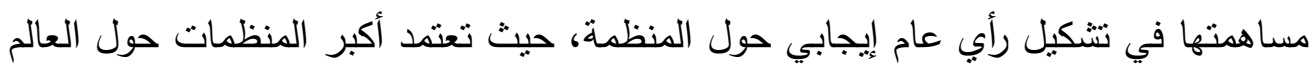

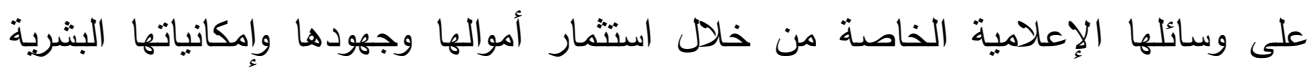

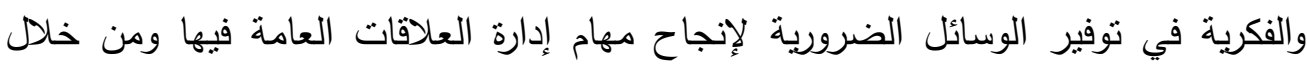

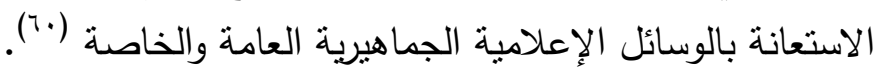

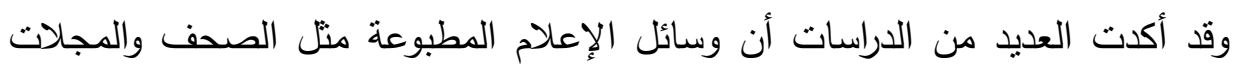

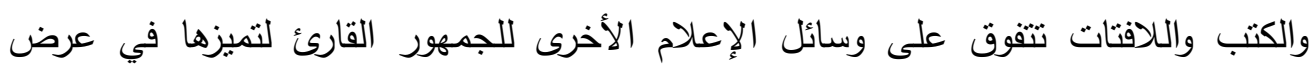

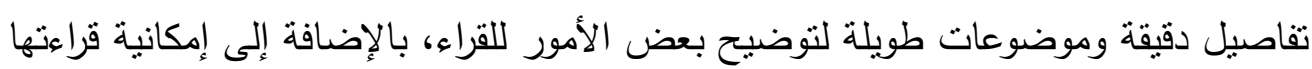

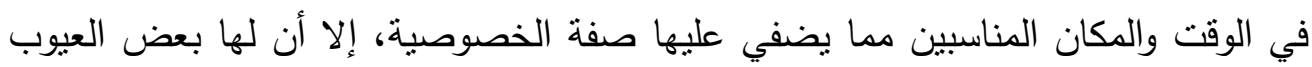
فهي تتطلب جمهور قارئ قادر على التخيل والتفسير والتركيز في الرسالة الإعلامية(الج).

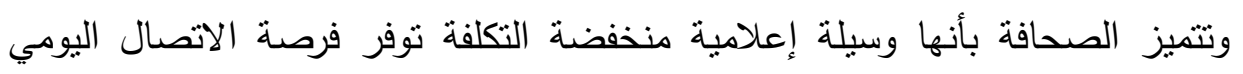

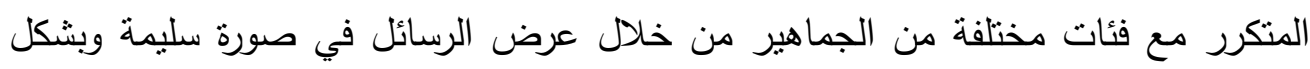

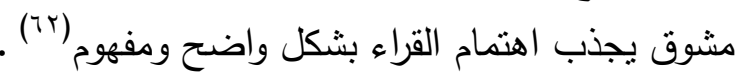

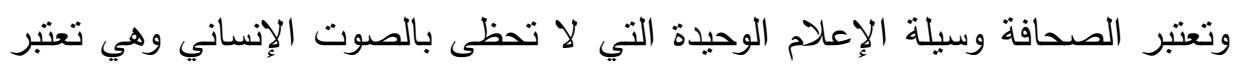

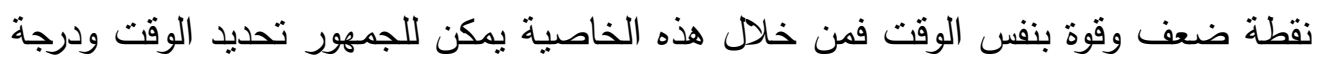

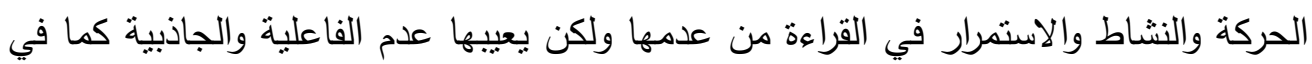

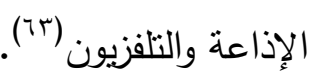

\section{الإجراعات المنهجية للاراسة:}

\section{نوع ومنهج الاراسة:}

تتنمي هذه الدراسة إلى الدراسات الوصفية وتستخدم منهج المسح الذي يعتبر من أنسب

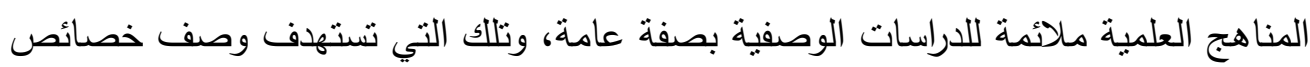

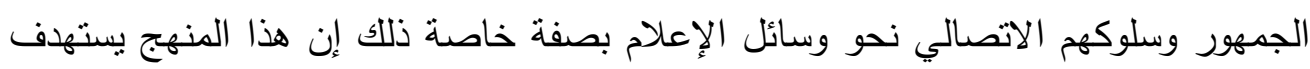
تسجيل وتحليل وتفسير الظاهرة في وضعها الراهن، بعد جمع البيانات اللازمة والكافية عنها لإنها

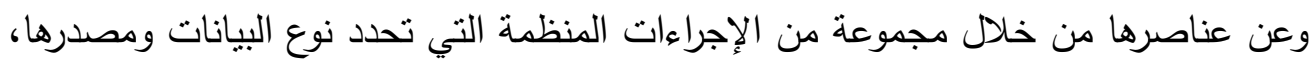
وطرق الحصول عليها(عَ). 
وتنتخدم الدراسة دنهج المسح الإعلامي بشقيه الميداني لعينة من أعضاء هيئة التدريس بجامعة تبوك والموظفين بها لرصد العوامل ذات العلاقة بتكوين الصورة الذهنية للجامعة

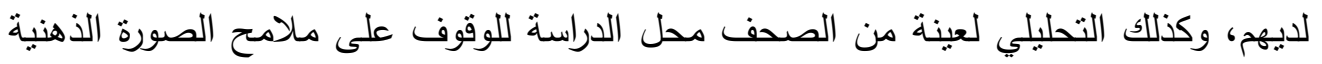

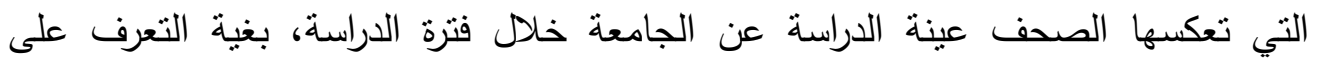

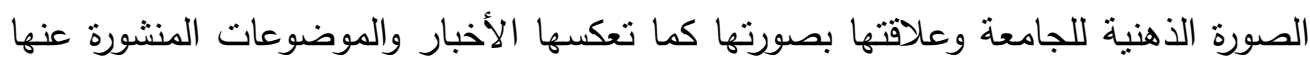
بالصحف عينة الدراسة. مجتمع وعينة الاراسة:

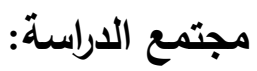
يتمثل مجتمع الاراسة الحالية في:-

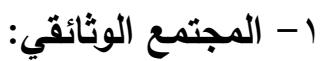

ويشمل الصحف اليومية السعودية (الرياض - المدينة - عكاظ - الوطن - الجزيرة الثرق )

r- المجتمع البشري: يتكون من أعضاء هيئة التدريس والموظفين بجامعة تبوك والذين

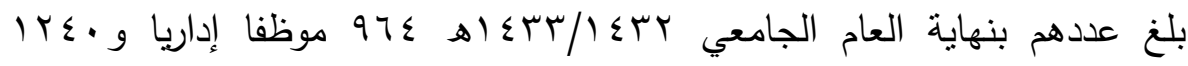
عضو هيئة تدريس بمختلف الدرجات العلمية وذلك وفقا للتقرير السنوي الثاني لعمادة شؤون أعضاء هيئة التدريس والموظفين بالجامعة. عينـة الدراسـة:

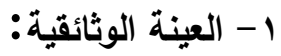
بعد الإطلاع علي الدراسات السابقة، ومن خلال المراجع العلمية المتخصصة في بحوث الإعلام فيما يتعلق بحجم العينات الكافي لإجراء الدراسة التحليلية، فقد حدد الباحث دراسته

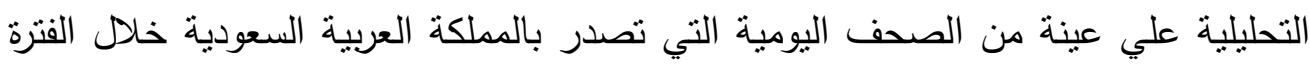

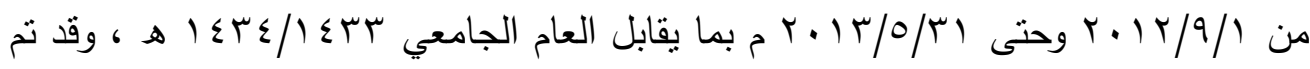

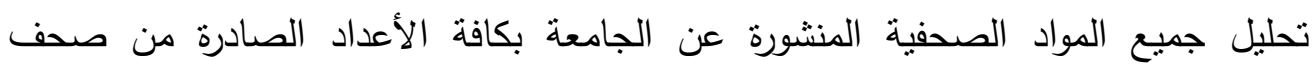

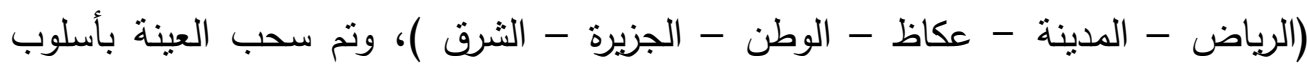

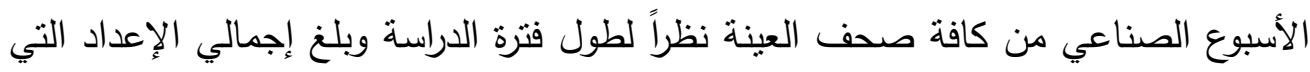
تم تحليلها من الصحف ع rr عدداً بواقع qr عدد من كل صحيفة خلال فترة الدراسة . 
جدول رقم ( ) يبين توزيع عينة الاراسة الوثائقية بحسب الصحيفة.

\begin{tabular}{|c|c|c|c|}
\hline$\%$ & (5) & الصحيقة & $p$ \\
\hline 17.74 & rq & الرياض & \\
\hline 17.74 & rq & المدينة & $r$ \\
\hline 18.74 & rq & عكاظ & ' \\
\hline 17.74 & rq & الوطن & $q$ \\
\hline 17.74 & rq & الجزيرة & $\theta$ \\
\hline 17.74 & ra & الثرق & 7 \\
\hline $1 \ldots$ & rTE & مالي & \\
\hline
\end{tabular}

r- ب - ب العينة البشرية: تم تطبيق الدراسة الميدانية على عينة من أعضاء هيئة التدريس والموظفين بجامعة أعضاء

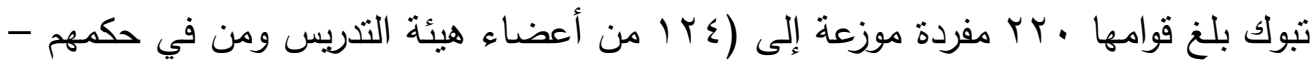

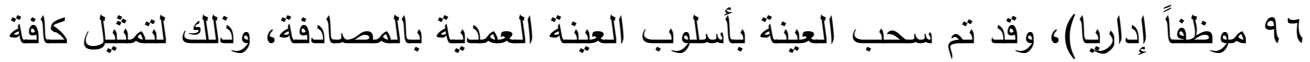

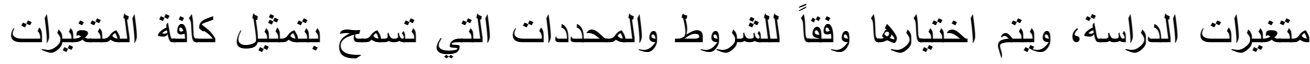

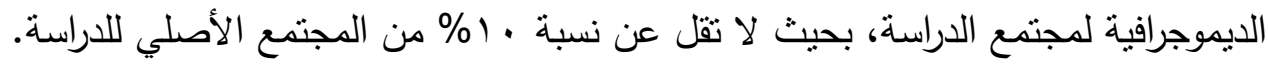

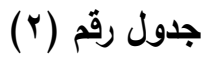

يبين توزيع عينة الدراسة البثرية بحسب ( النوع ، نوع العمل بالجامعة ، سنوات الخبرة، المؤهل ).

\begin{tabular}{|c|c|c|c|}
\hline النسبة \% & التكرار (ك) & المجموعات & المتغير \\
\hline $0 \leqslant .0$ & Tr. & ذكور & \multirow{3}{*}{ النوع النوع } \\
\hline$\leqslant 0.0$ & $1 \ldots$ & إناث & \\
\hline $1 \ldots$ & YY. & المجموع & \\
\hline 04.8 & Irs & عضو هيئة تدريس & \multirow{3}{*}{ نوع العمل بالجامعة } \\
\hline \&Y. & 97 & موظف إداري & \\
\hline $1 \ldots$ & rY. & الإجمالي & \\
\hline 10.9 & $r_{0}$ & عامان & \multirow{4}{*}{ سنوات الخبرة } \\
\hline$r \leqslant .0$ & $V 4$ & من عامين إلى أريعة أعوام & \\
\hline$\leqslant 9.0$ & 1.9 & أكتر من أربعة أعوام & \\
\hline $1 \ldots$ & YY. & المجموع & \\
\hline 0.9 & ir & متوسط متط & \multirow{6}{*}{ المؤهل } \\
\hline $1 \leqslant .0$ & rr & ثُانوية عامة & \\
\hline rT.r & 01 & بكالويوس & \\
\hline IN.Y & $\varepsilon$ & ماجستير & \\
\hline rA.r & $\Lambda \varepsilon$ & دكتوراه & \\
\hline $1 \ldots$ & Tr. & المجموع & \\
\hline
\end{tabular}

يتضح من الجدول السابق توزيع عينة الدراسة وفقا لمجموعة من الخصائص حيث

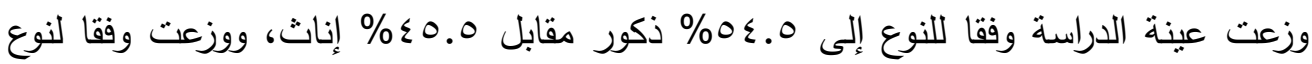




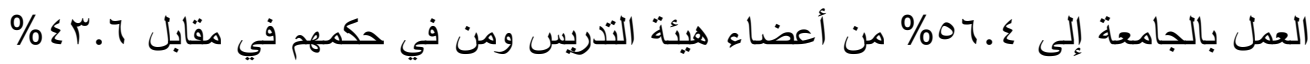
من الموظفين بالجامعة، وجاءت نسبة من تجاوزت خبراتهم في العمل أكثر من أربعة سنوات

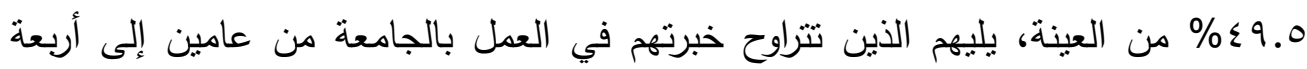

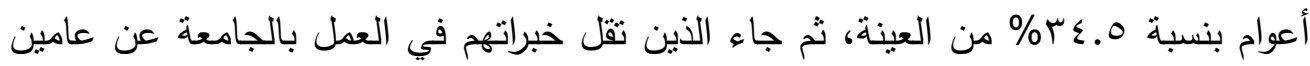
بنسبة 10.9\% من العينة، ووزعت العينة وفقا للمؤهل الدراسي للمبحوثين إلى نسبة

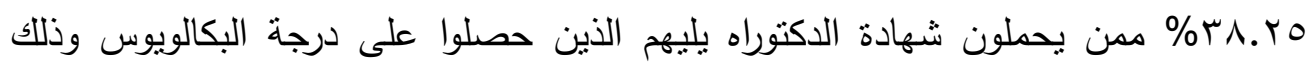

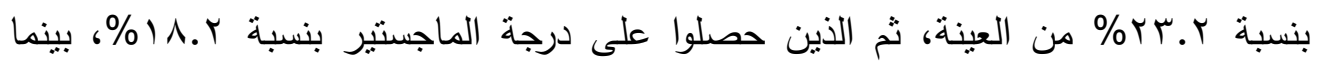

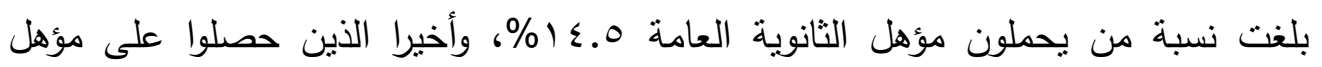
متوسط بنسبة 9.9 \% من العينة. أدوات وأسلوب جمع البيانات:

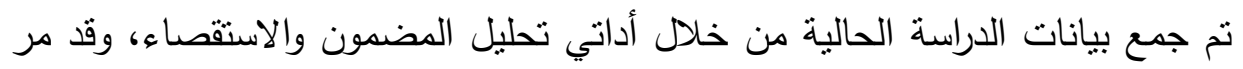
إعداد هذه الأدوات بالمراحل العلمية المتعارف عليها من تحديد الهدف والبيانات المطلوب من فئل جمعها وإعدادها في صورتها الأولية ومراجعتها منهجيا وعلميا من خلال مجموعة من الخبراء والمحكمين في مجالات الإعلام والتربية وتطبيق الاختبار القبلي Pre test وكذلك التأكد من الثبات قبل النطبيق النهائي على عينة الدراسة. صحيفة تحليل المضمون : تحديد وحدات وفئات التحليل:-

تحديد وحدات التحليل: استخدم الباحث وحدة الموضوع في تحليل مضمون الموضوعات الواردة عن الجامعة بالصحف عينة الدراسة ، وتعتبر وحدة الموضوع أكثر وحدات تحليل المحتوى استخداما في دراسة مادة الاتصال. فئات التحليل: تم اعداد صحيفة تحليل المضمون، التي تضمنت مجموعة من الفئات التي

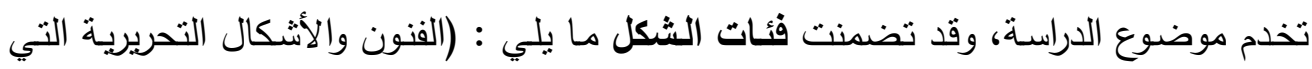

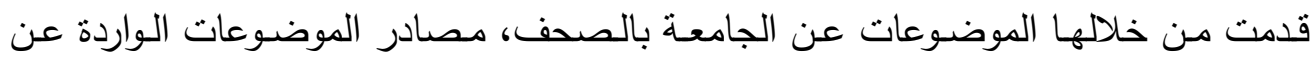
الجامعة بالصحف عينة الدراسـة، موقع المادة المنشورة عن الجامعة بالصحف عينة بالهنة الدراسة،

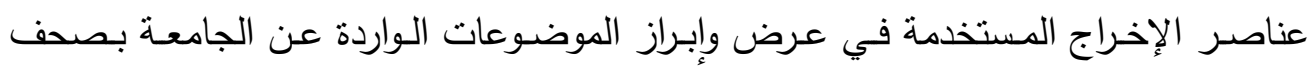
الدراسة) ، كما تضدنت فئات المضمون ما يلي: (أنواع الموضوعات الوضروات الواردة بالمواد التحريرية 
عن جامعة تبوك بالصحف، نوع المعالجة المستخدمة في عرض الموضوعات التي تتعلق

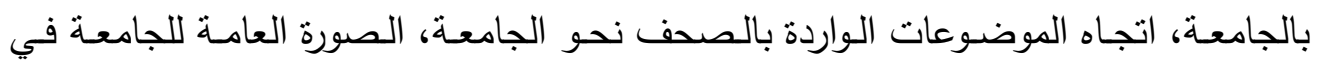
الموضوعات الواردة حولها بالصحف ) ـ وقد قسمت كل فئة من تللك الفئات إلى عدة فئات

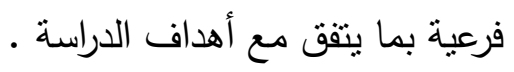

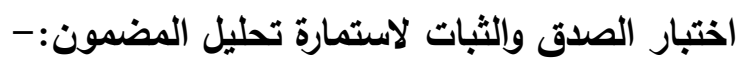
- اختبار الصدق :

للتأكد مـن صـدق اسـتمارة تحليـل المضمون تم عرضـهـا علـي مجموعـة مـن الخبراء والمحكمين في مجال الإعلام، وذللك للتأكد من دقة الاستمارة ووضوح وحدات وفئات التحليل،

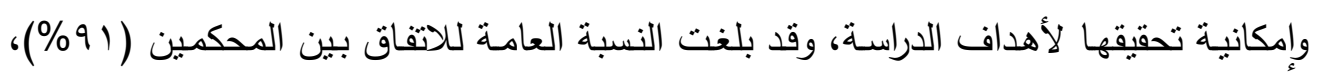
وفي ضوء آراء المحكمين أجريت بعض التعديلات على الاستمارة حتى أصبحت في شكلها النهائي.

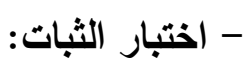

قام الباحث باختيار عينة من الصحف، وقام بتحليلها، ثم أعاد الباحث تحليل تلك العينة

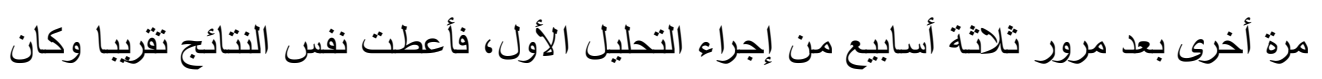

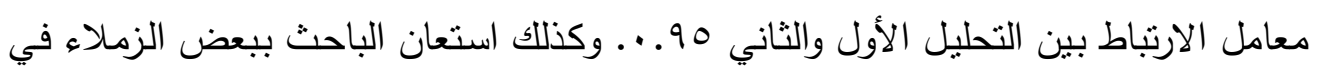

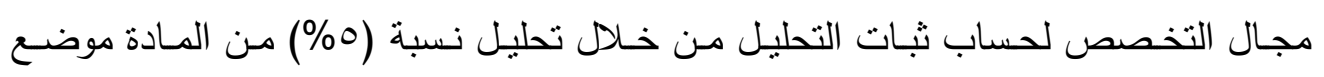
التحليل بنفس الوحدات والفئات بعد توضيحها لهم وتعريفهم بالهدف من الدراسة، وتم تزويدهم

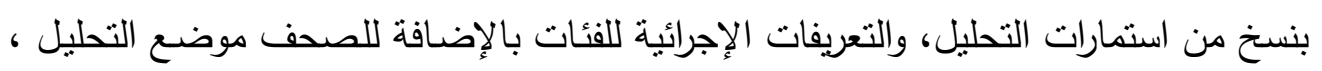

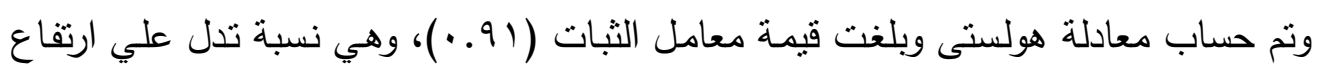
مستوى ثبات الوحدات، والفئات المستخدمة في تحليل المضمون ، كما تعني صلاحية استمارة

تحليل المضمون للنطبيق.(')

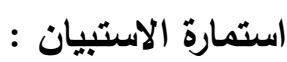

نم تصميم استمارة الاستبيان من خلال تحديد البيانات المطلوب جمعها من عينة

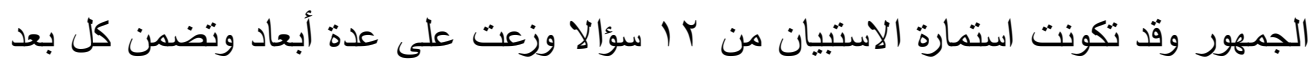

(") أسماء الزملاء الذين استعان بهم الباحث في حساب ثبات أدوات الدراسة: د/ هبة جمال الدين عابدين

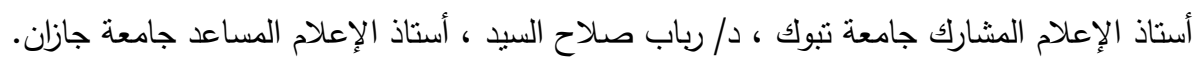


من هذه الأبعاد مجموعة من الأسئلة وفقا لأهداف الدراسة وتساؤلاتها كما يلي:-

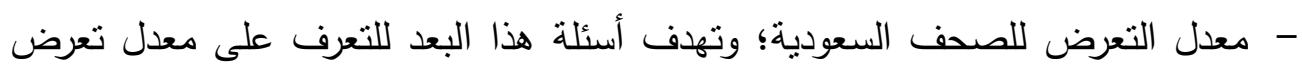

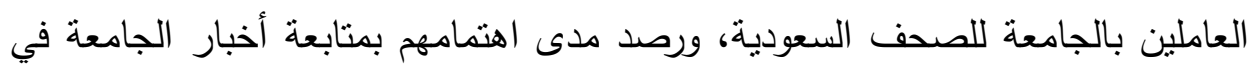

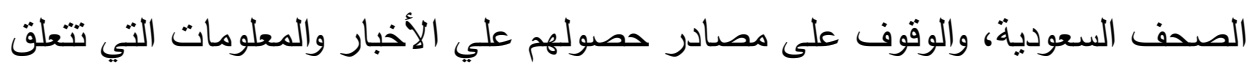
بالجامعة. - ملامح الصورة التي تقدمها الصحف السعودية عن الجامعة ثبوك وتحديد أبرز الملامح

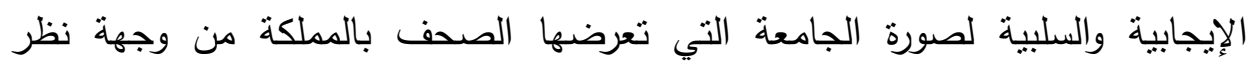

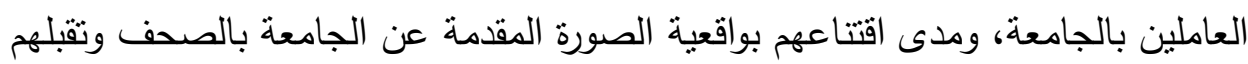

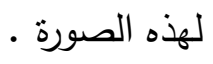

- تقييم العاملين بالجامعة لأدائها، ومعرفة الجهود التي تبذلها لتحسين صورتها لدى

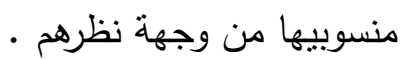
- كما تضمنت صحيفة الاستبيان على البيانات الأولية للعينة بهدف معرفة المتغيرات

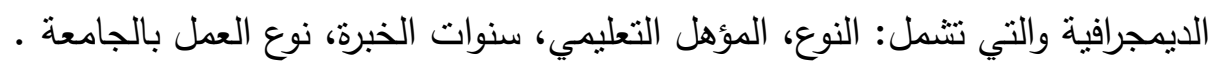

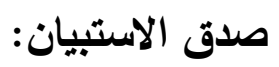

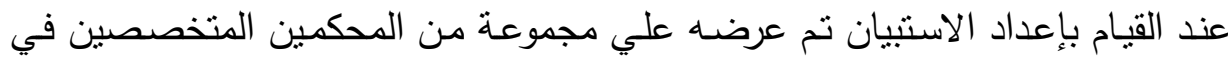

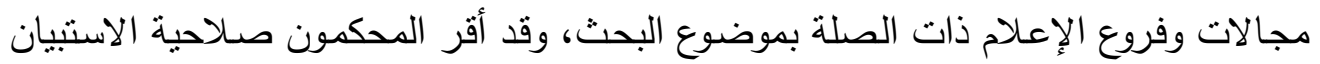

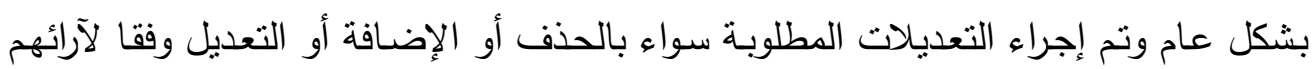

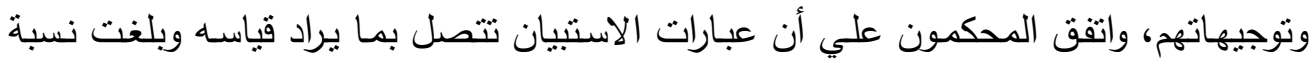

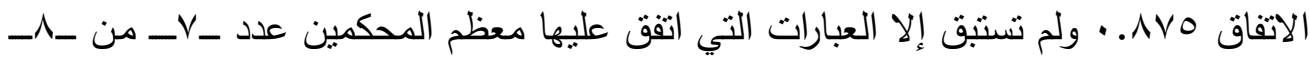
العدد الكلي للمحكمين.

كما تم التحقق مـن صدق الاتساق الداخلي عن طريقف حساب معامـل الارتباط بين

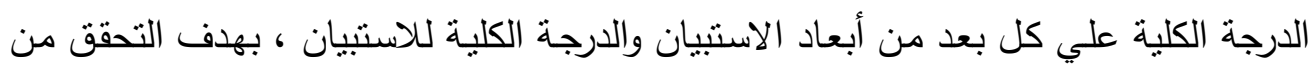

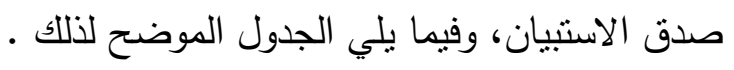
جدول (广) (َ)

معاملات صدق الاتساق الااخلي بين الارجة الكلية لكل بعد والارجة الكلية للاستبيان .

\begin{tabular}{|c|c|c|}
\hline 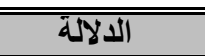 & الارتباط مع الدرجة الكلية & 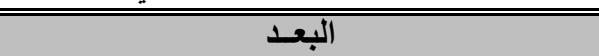 \\
\hline دالة عند 1... & **..Arr & التعرض لأخبار الجامعة في الصحف \\
\hline دالة غند ا ... & $* * ., \wedge Y \xi$ & ملامح الصورة الذهنية التي تعكسها الصحف عن \\
\hline دالة عند ا •. & $* * . . \vee \diamond q$ & واقعية الصورة المقدمة بالصحف عن الجامعة \\
\hline دالة عند ا ... & $* * . . \wedge \leq \nearrow$ & تقييم العاملين بالجامعة لأدائها \\
\hline
\end{tabular}


يوضح الجدول أن معامل الارتباط بين درجة كل بعد من أبعاد ومجالات الاستبيان

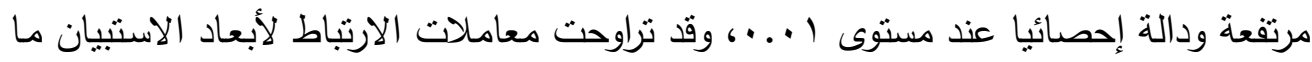

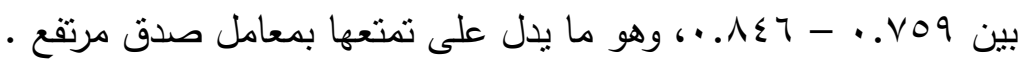

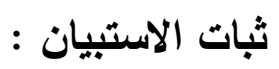
قام الباحث بحساب معامل ثبات الاستبيان، وفقا لطريقة التجزئة النصفية لجتمان، وكذللك عن طريق حساب معامل ارتباط سبيرمان وبراون. جدول رقم (ع) - معاملات ثبات الاستبيان وأبعاده وفقا لطريقتي (التجزئة النصفية لجتمان - سبيرمان وبراون) -

\begin{tabular}{|c|c|c|c|}
\hline سبيزيزان - سبراون & التجزئة النصفية & 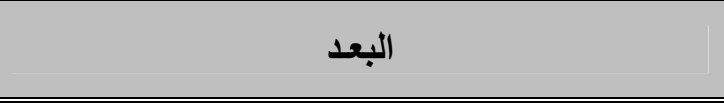 & r \\
\hline$* * . . \wedge \vee$ & $* * . . \wedge \uparrow$ & التعرض لأخبار الجامعة في الصحف & 1 \\
\hline$* * . . \wedge$ & $* * . . \wedge \leqslant$ & ملامح الصورة الذهنية التي تعكسها الصحف عن الجامعة & $r$ \\
\hline$* * . . \vee q$ & $* * . .1$ & واقعية الصورة المقدمة بالصحف عن الجامعة & $r$ \\
\hline$* * . . \wedge \varepsilon$ & $* * . \wedge \wedge$ & تقييم العاملين بالجامعة لأدائها & $\varepsilon$ \\
\hline$* * . . \wedge V$ & $* * . \wedge q$ & معامل ارتباط الأبعاد مع بعضها & * \\
\hline$* * . . \wedge 9$ & $* * . \wedge \wedge$ & ارتباط الأبعاد مع الارجة الكلية & ** \\
\hline
\end{tabular}

يتضح من الجدول السابق أن أبعاد الاستبيان حققت معاملات ثبات علي درجة معقولة

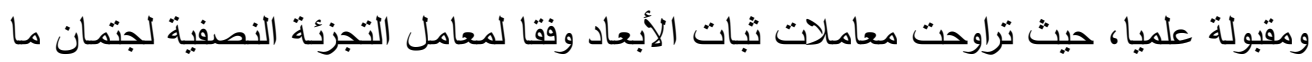

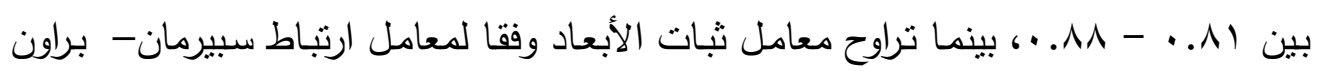

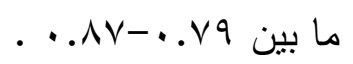
- وفيما يتعلق بمعاملات ارتباط الأبعاد مـع بعضها فقد كانت 19. . وفقا لمعامل ارتباط

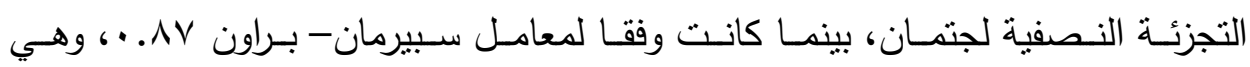

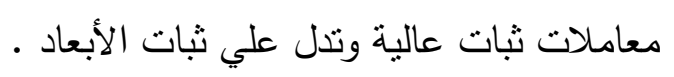

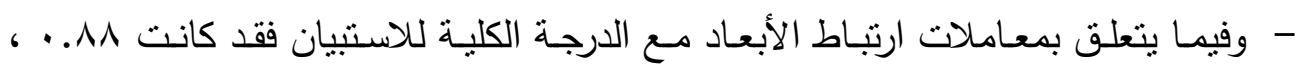

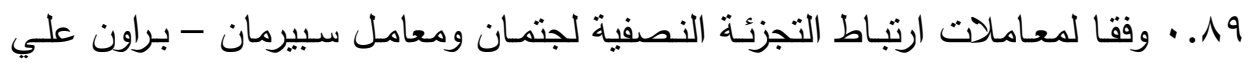
الترتيب وهي معاملات ثبات عالية وتثير إلي ثبات الاستيبان وصلاحيته للاستخدام. الأساليب الإحصائية المستخدمة في الاراسة: قام الباحث بإجراء التحليل الإحصائي لبيانات هذه الإداسة باستخدام برنامج

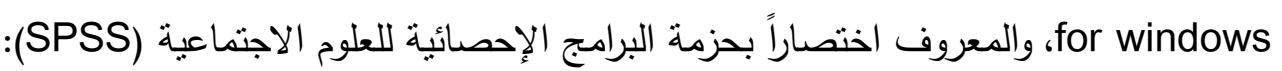

Statistical Package for social science 
وتم استخدام الاختبارات الإحصائية التالية:

$$
\text { 1- التكرارات البسيطة والنسب المئوية. }
$$

r- الوزن المرجح الذي يحسب بضرب التكرارات بوزن معين يقرره الباحث استتاداً إلي عدد التبد

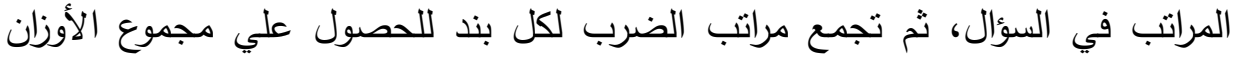
المرجحة، ثم تحسب النسب المئوية لبنود السؤال كلها. r- تحليل التباين ذي البعد الواحد ANOVA لدراسة الفروق الإحصائية بين المتوسطات الحسابية للمجموعات علي أحد متغيرات الدراسة. ع - معامل ارتباط بيرسون Pearson Correlation Coefficient لدراسة شدة واتجاه العلاقة الارتباطية بين متغيرين من مستوى المسافة أو النسبة.

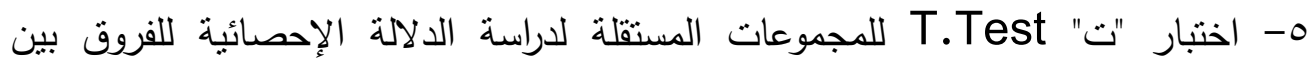
متوسطين حسابيين لمجموعتين من المبحوثين في أحد متغيرات الدراسة.

\section{نتائج الارلسة التحليلية :}

يتتاول هذا الجزء نتائج مسح محتوى الفنون التحريرية لعينة من الصحف السعودية

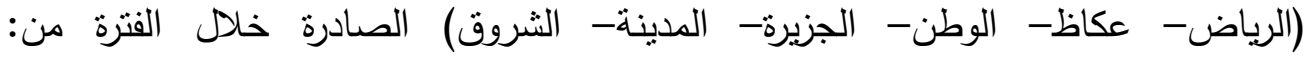

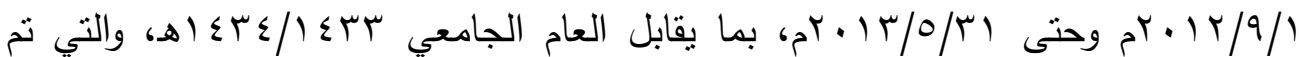

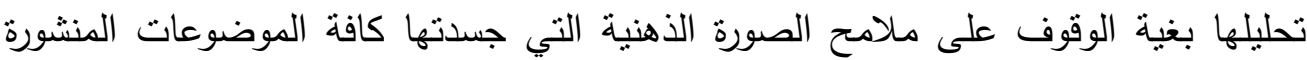
حول جامعة تبوك، وذللك للإجابة عن تساؤلات الدراسة التحليلية، وفيما يلي عرضاً لنتائج الدراسة التحليلية التي أجريت على ودئ العينة التحليلية.

1 - الفنون التحريرية التي قدمت من خلالها الموضوعات عن الجامعة بالصدف السعودية. جدول رقم (0)

تكرارات ونسب الفنون والأثكال التحريرية التي قدمت من خلالها الموضوعات عن الجامعة بالصحف عينة الدراسة.

\begin{tabular}{|c|c|c|c|c|c|c|c|c|c|c|c|c|c|c|}
\hline \multicolumn{2}{|c|}{ الإجمالي } & \multicolumn{2}{|c|}{ الشرق } & \multicolumn{2}{|c|}{ الجزيرة } & \multicolumn{2}{|c|}{ الوطن } & \multicolumn{2}{|c|}{ عكاظ } & \multicolumn{2}{|c|}{ المدينة } & \multicolumn{2}{|c|}{ الرياض } & \multirow{2}{*}{ القوالب/2 لريفة } \\
\hline$\%$ & 5 & $\%$ & 5 & $\%$ & ك & $\%$ & ك5 & $\%$ & ك & $\%$ & 5 & $\%$ & ك5 & \\
\hline 10.7 & $r \leqslant \xi$ & VA.YY & r & 10.19 & $\leqslant 7$ & 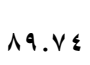 & ro & QY.० & ir & Aז.AV & Y & $\wedge \varepsilon . \vee \wedge$ & rq & خبر \\
\hline$\wedge . \wedge$ & ro & IV.ra & $\wedge$ & 11.11 & 7 & 8.79 & $r$ & $r .99$ & $r$ & $7 . \leqslant 0$ & $r$ & ^.v. & $\varepsilon$ & تقرير \\
\hline r.o & v & $7.0 Y$ & $r$ & $\cdots$ & • & r.04 & 1 & $\cdots$ & $\cdot$ & $7 . \leqslant 0$ & $r$ & r.IV & 1 & مقال \\
\hline$r . r$ & 9 & r.IV & 1 & r.v. & r & $\cdots$ & · & $\varepsilon . \leqslant \wedge$ & $r$ & r.rT & 1 & S.r. & r & حليث \\
\hline $1 \ldots$ & $r \wedge 0$ & $1 \ldots$ & $\leqslant \wedge$ & $1 \ldots$ & $0\}$ & $1 \ldots$ & $r q$ & $1 \ldots$ & IV & $1 \ldots$ & rI & $1 \ldots$ & $\leq 7$ & الإجمالي \\
\hline
\end{tabular}

• يتضح مـن نتائج الجدول السابق أن الخبر الصحفي جـاء في مقدمـة فنـون التحريـر الصحفي التي استخدمتها الصحف السعودية في عرض الموضوعات التي تتعلق بالجامعة 
بنسبة بلغت 7 ـ \% من إجمالي القوالب المستخدمة في تتاول المـادة الصحفية المقدمـة عن جامعة تبوك بصحف العينة، وكانت صحيفة عكاظ أكثر صحف العينة نشراً للأخبار

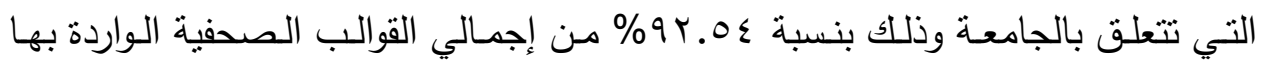
حول الجامعة بينما كانت صحيفة الثرق أقل الصحف عرضـا للموضوعات الإخباربة عن باته

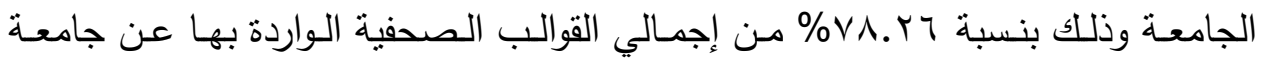

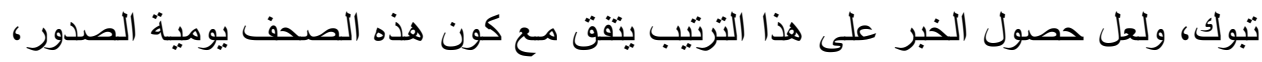

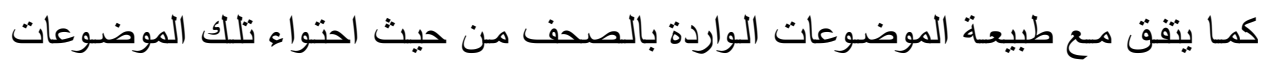
على بعض القيم الخبرية التي تؤهلها للنشر بالصوفئ.

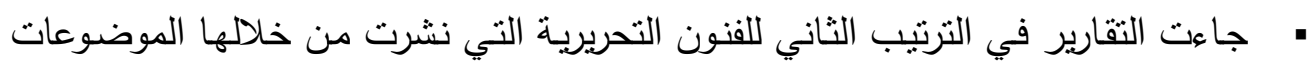

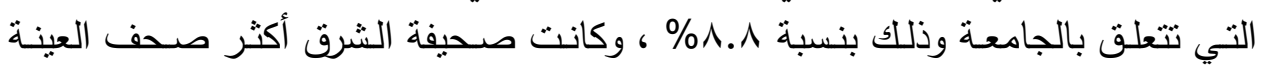

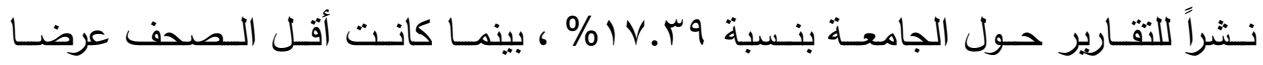
لموضوعات جامعة تبوك في هذا القالب صحيفة عكاظ وذلك بنسبة 99. 9 \% من إجمالي

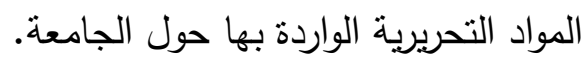

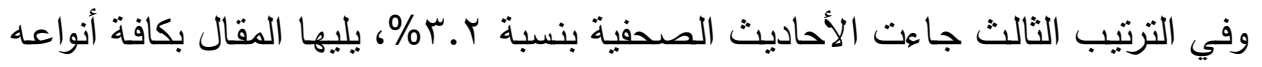
بنسبة ه. \% من إجمالي الموضوعات الصحفية الواردة عن الجامعة بصحف الدراسة.

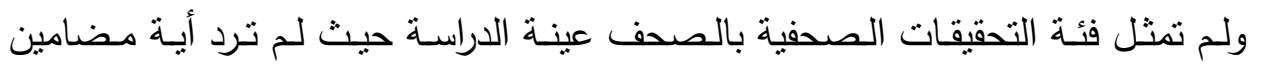

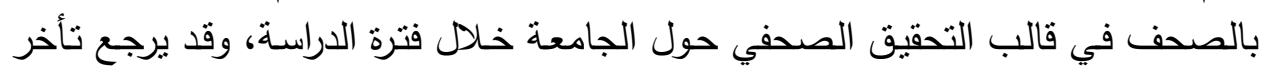
الأشكال التفسيرية من بين فنون التحرير المستخدمة بالنسبة لعدد تكراراتها إلي أنها تحتاج إلي مساحات أكبر ومعالجة أعمق للمضامين المقدمة من خلالها، ولذا قل عدد الأحاديث واختقت التحقيقات المقدمة بالصحف عينة الدراسة بالمقارنة بالقوالب الصحفية الأخرى. r- مصادر الموضوعات الواردة عن الجامعة بالصحف عينة الدراسة.

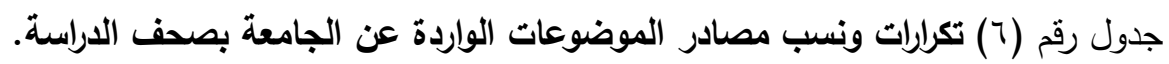

\begin{tabular}{|c|c|c|c|c|c|c|c|c|c|c|c|c|c|c|}
\hline \multicolumn{2}{|c|}{ الإجمالي } & \multicolumn{2}{|c|}{ الشرق } & \multicolumn{2}{|c|}{ الجزيرة } & \multicolumn{2}{|c|}{ الوطن } & \multicolumn{2}{|c|}{ عكاظ } & \multicolumn{2}{|c|}{ المدينة } & \multicolumn{2}{|c|}{ الرياض } & \multirow{2}{*}{ المصادر الصحيفة } \\
\hline$\%$ & ك & $\%$ & 5 & $\%$ & ك5 & $\%$ & ك & $\%$ & ك & $\%$ & ك & $\%$ & ك5 & \\
\hline R..rt & 199 & VY.qT & ro & vo.9r & \&1 & $\vee q . \leqslant 9$ & M & $v \cdot .10$ & $\leqslant V$ & 71.49 & 19 & $07.0 \mathrm{r}$ & ז & صحفي \\
\hline 9.19 & rᄉ & Ir.o. & 7 & 9.14 & 0 & $1 . . r 7$ & $\varepsilon$ & r.99 & r & 9.71 & r & $18 . r 9$ & $\wedge$ & والسعودية الأنباء \\
\hline r.А9 & 11 & $\cdots$ & - & $\cdots$ & . & r.07 & 1 & $V . \varepsilon \uparrow$ & 0 & 9.71 & r & E.To & r & المتحثث الرسمي \\
\hline r.or & 1. & T.ro & r & $\cdots$ & . & $\cdots$ & · & $0.9 V$ & $\varepsilon$ & $7 . \leqslant 0$ & r & T.IV & 1 & مسئول بالجامعة \\
\hline 7.71 & 19 & $r . \cdot \Lambda$ & 1 & r.v. & r & $0.1 \pi$ & r & $1 . . \leqslant 0$ & V & 9.71 & r & A.v. & $\varepsilon$ & مصادر أخرى \\
\hline ד. & 11 & T.Y० & r & 11.11 & 1 & T.07 & 1 & T.99 & r & r.rt & 1 & $1 \cdot . \wedge \mathrm{V}$ & 0 & غير محددة المصدر \\
\hline $1 \ldots$ & rAo & $1 \ldots$ & $\leqslant 1$ & $1 \ldots$ & $0 \leqslant$ & $1 \ldots$ & rq & $1 \ldots$ & TV & $1 \ldots$ & ए & $1 \cdots$ & $\leq 7$ & الإجمالي \\
\hline
\end{tabular}


بتضح من بيانات الجدول السابق أن الصحف عينة الدراسة اعتمدت في المقام الأول علي محرريها في تتاول الموضوعات الخاصة بالجامعة على صفحاتها، وذلك بنسبة

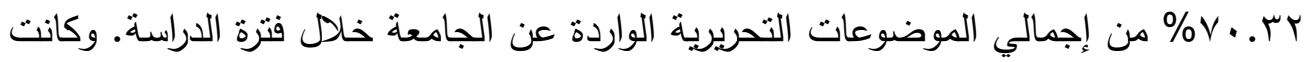
صحيفة الوطن أكثر الصحف اعتمادا على محرريها في نشر الموضوعات الواردة عن لهن

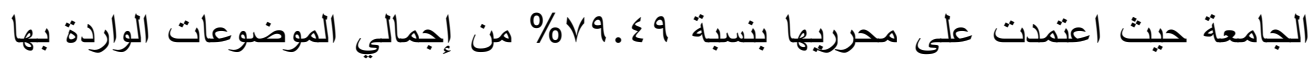
عن الجامعة، بينما كانت صحيفة الرياض أقل الصحف اعتمادا على محرريها في نشر إنى

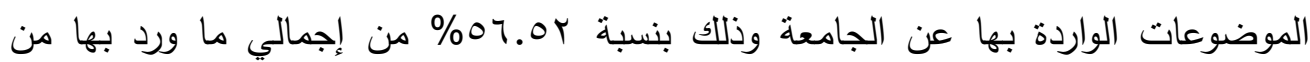
موضوعات عن الجامعة. كما كثفت الدراسة أن نسبة ^.9\% من الموضوعات التحريرية الواردة بالصحف حول

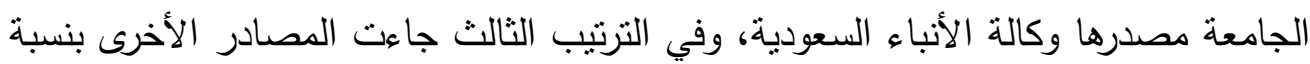

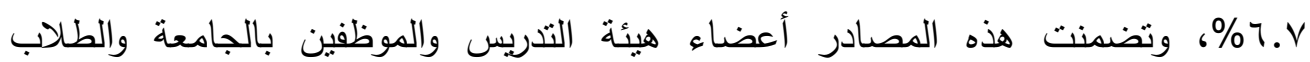

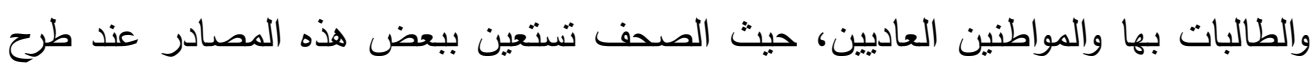
وتتاول القضايا المختلفة وخاصة التي ترتبط بالتعليم العالي لخدمة القضايا التي تتبناها، وطرح آرائهم وخبراتهم للجمهور للتعبير عن اتجاهاتهم وقضاياهم وآرائهم، إما دعوة وتثتينا للإيجابي منها، وإما توعية وتثبيطا للسلبي من تلك القضايا والتوجهات. وفي الترتيب الرابع لمصادر الموضوعات الواردة عن الجامعة بصحف الدراسة جاءت الموضوعات المنشورة بدون مصدر محدد وهو ما ينسب إلي هذه الصحف ذاتها وذللك بنسبة

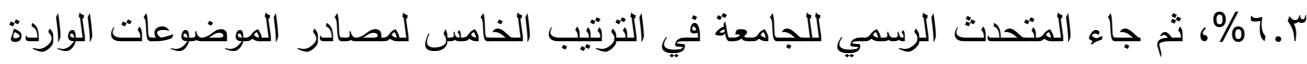
عن الجامعة بالصحف وذلك بنسبة 9.ب\%، وأخيراً جاء المسئولون بالجامعة كمصدر

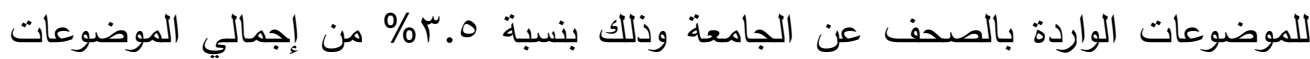
الواردة عن الجامعة بصحف الدراسة. ويمكن تفسير ذلك في ضوء نتائج الجدول الخاص بالفنون والأشكال الصحفية والذي أوضح أن الأخبار كانت في الترتيب الأول ضمن الأشكال المنشورة عن الجامعة على بلى

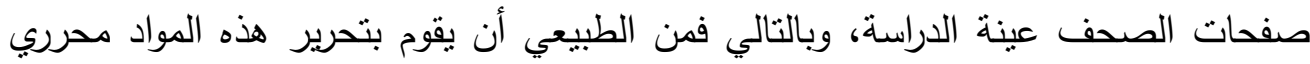

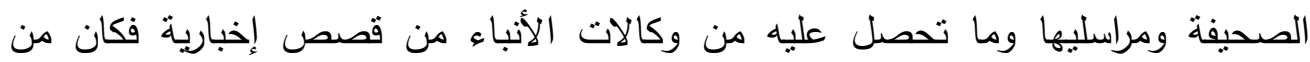
الطبيعي أن تكون مصادر الحصول على الموضوعات الصحفية المحرين الصحفيين ووكالات الأنباء، وهكذا جاءت النتائج منسقة فيما بين الجدولين. 
العدد الثانى - يونيو ؛ 1 • ب (الجزء الرابع)

المجلة العلمية لكلية التربية النوعية

ع - موقع المادة المنشورة عن الجامعة بالصحف عينة الدراسة.

جدول رقم V) توزيع موقع المادة المنشورة عن الجامعة بالصحف عينة الاراسة.

\begin{tabular}{|c|c|c|c|c|c|c|c|c|c|c|c|c|c|c|}
\hline \multicolumn{2}{|c|}{ الإجمالي } & \multicolumn{2}{|c|}{ الشرق } & \multicolumn{2}{|c|}{ الجزيرة } & \multicolumn{2}{|c|}{ الوطن } & \multicolumn{2}{|c|}{ عكاظ } & \multicolumn{2}{|c|}{ المدينة } & \multicolumn{2}{|c|}{ الرياض } & \multirow{2}{*}{ موقع المادةز } \\
\hline$\%$ & 5 & $\%$ & ك & $\%$ & ك & $\%$ & ك & $\%$ & ك & $\%$ & ك & $\%$ & ك & \\
\hline r.11 & 7 & క.1V & $r$ & . & . & $\cdots$ & . & r.99 & r & T.rT & 1 & T.IV & 1 & الأولى \\
\hline $9 \varepsilon . V \varepsilon$ & $r v$. & 9 q.V० & $\leq 0$ & $1 \ldots$ & $0 \leqslant$ & QY.r. & T4 & $q \leq \ldots r$ & זד & 94.00 & rq & $9 r . \leqslant 1$ & $\varepsilon r$ & الداخلية \\
\hline 5.17 & 9 & r... & 1 & . & . & $V .79$ & $r$ & r.99 & r & T.MT & 1 & S.ro & r & الأخفيرة \\
\hline $1 \ldots$ & r 10 & $1 \ldots$ & $\leqslant 1$ & $1 \ldots$ & $0 \leqslant$ & $1 \ldots$ & rq & $1 \ldots$ & TV & $1 \ldots$ & ו & $1 \ldots$ & $\leqslant 7$ & الإجمالي \\
\hline
\end{tabular}

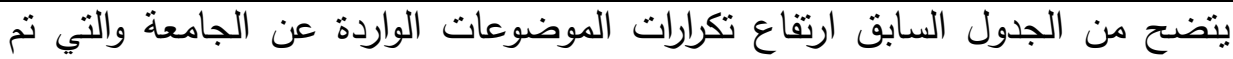

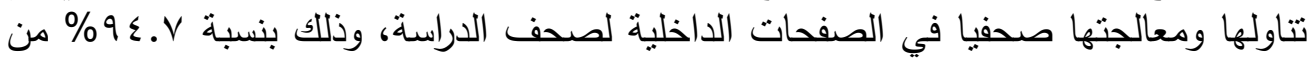

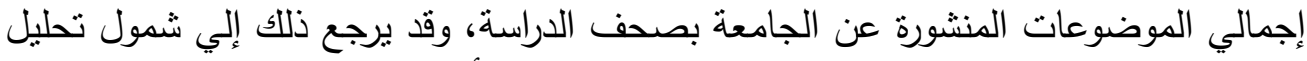

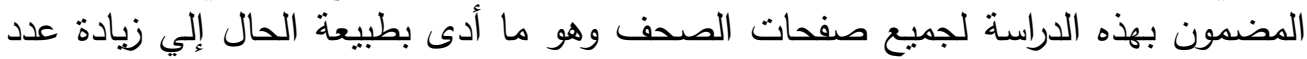

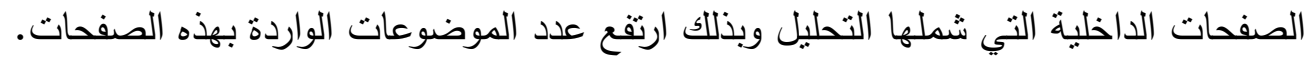

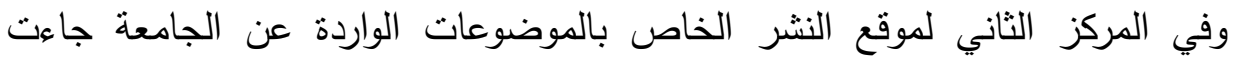

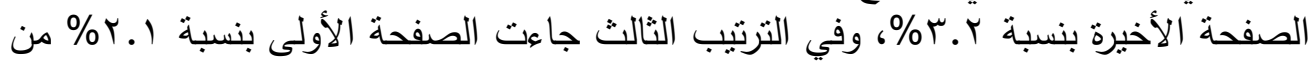

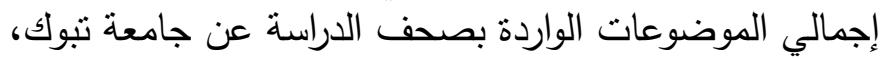

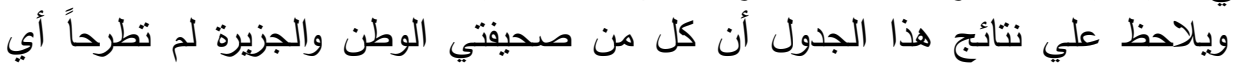

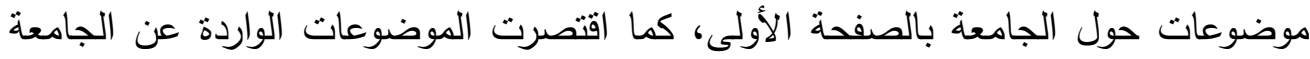

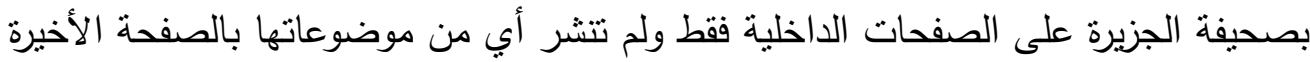

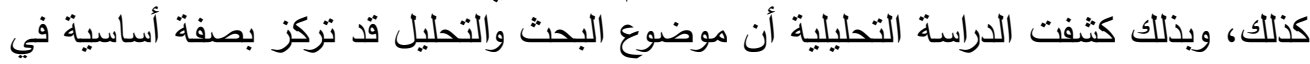

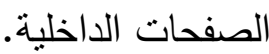

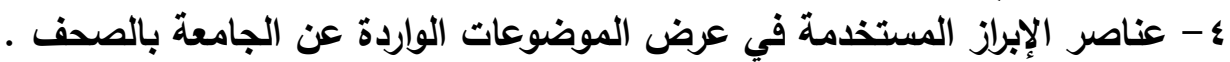

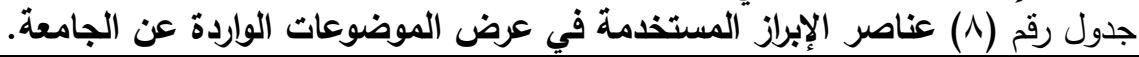

\begin{tabular}{|c|c|c|c|c|c|c|c|c|c|c|c|c|c|c|}
\hline \multicolumn{2}{|c|}{ الإجمالي } & \multicolumn{2}{|c|}{ الثرق } & \multicolumn{2}{|c|}{ الجزيرة } & \multicolumn{2}{|c|}{ الوطن } & \multicolumn{2}{|c|}{ عكاظ } & \multicolumn{2}{|c|}{ المدينة } & \multicolumn{2}{|c|}{ الرياض } & \\
\hline$\%$ & ك & $\%$ & ك & $\%$ & ك & $\%$ & ك & $\%$ & ك & $\%$ & s & $\%$ & ك & \\
\hline$\sum 7.1 Y$ & roo & $\varepsilon 1 . \Gamma \wedge$ & $\varepsilon \wedge$ & $\varepsilon \vee . \vee q$ & $0 \xi$ & 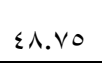 & rq & $\varepsilon 9.14$ & IV & $\sum 1.19$ & r & $\{7 . \leqslant 7$ & $\leqslant 7$ & العناوين \\
\hline $11 . \leqslant 0$ & $11 \varepsilon$ & rY.乏) & rT & 11.01 & YI & 1T.Vo & 11 & $r . .09$ & rA & 17.17 & 9 & 19.19 & 19 & الصور \\
\hline $1.0 \%$ & 70 & $1 \leq .74$ & IV & $1 . .75$ & Ir & V.o. & 7 & 9.07 & $1 \pi$ & $1 . .11$ & $\wedge$ & $9 . .9$ & 9 & أدوات الفصل \\
\hline 1.59 & $\wedge$ &. .17 & 1 & $\ldots$ & . & Y.O. & r & $\ldots$ & . & $\varepsilon . .0$ & $r$ & r... & r & الرسوم \\
\hline ᄉ. $\varepsilon 1$ & or & 7.9. & $\wedge$ & $9 . V r$ & 11 & 17.50 & 15 & «.乏1 & 7 & 15.17 & 9 & 0.00 & 0 & الأرضيات \\
\hline 10.51 & $9 \varepsilon$ & $15 . v 9$ & 17 & IT.TV & 10 & $11 . r_{0}$ & 9 & 17.11 & rY & 11.94 & $1 \varepsilon$ & 11.11 & 11 & الألوان \\
\hline $1 \ldots$ & 711 & $1 \ldots$ & 117 & $1 \ldots$ & $11 \%$ & $1 \ldots$ & A. & $1 \ldots$ & 147 & $1 \ldots$ & $V \varepsilon$ & $1 \ldots$ & 99 & الإجمالي \\
\hline
\end{tabular}


يتضح من نتائج الجدول السابق أن العناوين جاءت في مقدمة عناصر الإخراج المستخدمة في عرض وإبراز الموضوعات المقدمة عن جامعة تبوك بصحف الدراسة إذ بن بأن

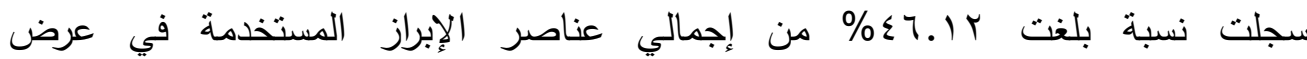
الموضوعات المقدمة بالصحف حول الجامعة.

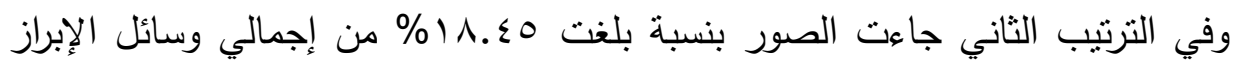

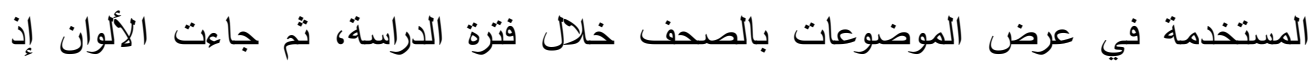

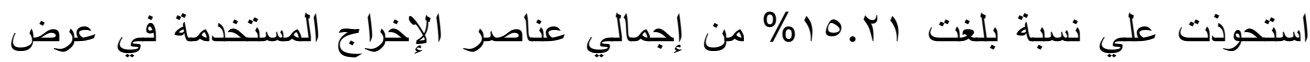
وإبراز الموضوعات المقدة بالصحف خلال فترة الدراسة، يليها عناصر الفصل بين الفهل الموضوعات المختلفة والتي تتضمن الإطارات والفواصل والجداول والزوايا بنسبة بلغت

$$
\text { . \%1..or }
$$

وفي الترتيب الخامس جاءت الأرضيات بنسبة بلغت اءــ\% وأخيرا جاءت الرسوم بأنواعها المختلفة ضمن عناصر الإخراج المستخدمة في عرض وإبراز الموضوعات المقدمة عن جامعة تبوك بصحف الدراسة بنسبة بلغت 9 ؟. 1\%

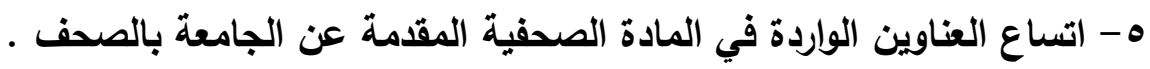
جدول رقم (9) تكرارات ونسب اتساع العناوين الواردة عن جامعة تبوك بالصحف .

\begin{tabular}{|c|c|c|c|c|c|c|c|c|c|c|c|c|c|c|}
\hline \multicolumn{2}{|c|}{ الإجمالي } & \multicolumn{2}{|c|}{ الثرق } & \multicolumn{2}{|c|}{ الجزيرة } & \multicolumn{2}{|c|}{ الوطن } & \multicolumn{2}{|c|}{ عكاظ } & \multicolumn{2}{|c|}{ المدينة } & \multicolumn{2}{|c|}{ الرياض } & \multirow{2}{*}{ إتساع العناوينز } \\
\hline$\%$ & ك & $\%$ & ك & $\%$ & ك5 & $\%$ & ك & $\%$ & ك & $\%$ & ك & $\%$ & ك & \\
\hline איד.T & דr & $1 \leq .01$ & v & $17.7 \mathrm{~V}$ & 9 & $10 . r \Lambda$ & 7 & $11.9 \leq$ & $\wedge$ & 14.9. & $\varepsilon$ & s.ro & r & عريض \\
\hline r9.70 & $11 \pi$ & $0 \leq .1 \mathrm{~V}$ & r & rᄉ.یq & YI & $\leqslant 7.10$ & 11 & r9.10 & $r$. & $\leq 1.9 \leq$ & r & II.Tr & 10 & ممتد \\
\hline$\Sigma V \cdot V Y$ & 4או & M. T. & 10 & $\leq \varepsilon . \leqslant \leq$ & $r \varepsilon$ & ץ & 10 & $O \wedge . Y_{1}$ & rq & $\leqslant 0.17$ & $1 \varepsilon$ & & rq & عمودي \\
\hline $1 \ldots$ & r10 & $1 \ldots$ & $\varepsilon \wedge$ & $1 \ldots$ & os & $1 \ldots$ & rq & $1 \ldots$ & TV & $1 \ldots$ & r & $1 \ldots$ & $\leq 7$ & الإجمالي \\
\hline
\end{tabular}

يتضح من الجدول السابق أن العناوين العمودية جاءت في مقدمة أنواع العناوين التي استخدمتها الصحف في إخراج الموضوعات الصحفية الواردة عن الجامعة بها بنسبة \%乏V.VY من إجمالي العناوين الواردة بالموضوعات المقدمة عن الجامعة بالصحف، وفي

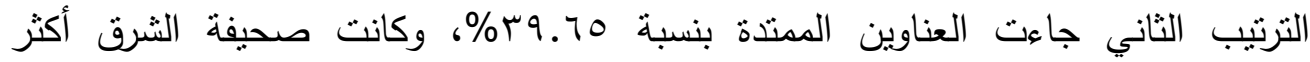
الصحف استخداما للعناوين الممتدة في إبراز الموضوعات الواردة عن الجامعة خلا فترة فيكة الدراسة وذلك بنسبة VI٪\% من إجمالي العناوين المستخدمة بها في إبراز الموضوعات 
الواردة عن الجامعة، بينما كانت صحيفة عكاظ أقل الصحف استخداما لهذا النوع من العناوين

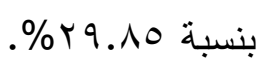

وفي الترتيب الثالث والأخير لأنواع العناوين من حيث الاتساع جاءت العناوين العربضة

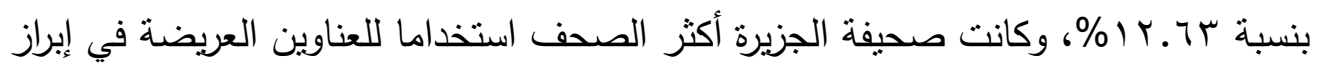

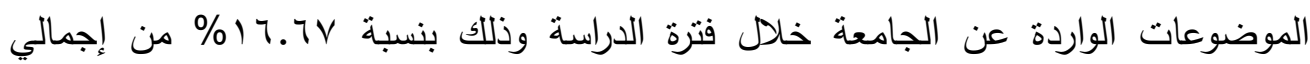
العناوين المستخدمة بها في إبراز الموضوعات الواردة عن الجامعة، بينما كانت صحيفة

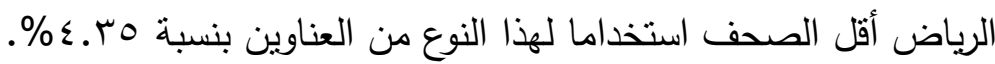
צ - أنواع الصور المستخدمة في المادة الصحفية المقدمة عن الجامعة بالصحف.

$$
\text { جدول رقم (1.) }
$$

\begin{tabular}{|c|c|c|c|c|c|c|c|c|c|c|c|c|c|c|}
\hline \multicolumn{2}{|c|}{ الإجمالي } & \multicolumn{2}{|c|}{ الشرق } & \multicolumn{2}{|c|}{ الجزيرة } & \multicolumn{2}{|c|}{ الوطن } & \multicolumn{2}{|c|}{ عكاظ } & \multicolumn{2}{|c|}{ المدينة } & \multicolumn{2}{|c|}{ الرياض } & \multirow{2}{*}{ أنواع الصوحيفة } \\
\hline$\%$ & ك & $\%$ & ك & $\%$ & ك & $\%$ & ك & $\%$ & ك5 & $\%$ & ك & $\%$ & ك & \\
\hline $00 . Y 7$ & Tז & $\leqslant 7.10$ & Ir & ov.ls & Ir & $\leqslant 0 . \leqslant 0$ & 0 & $7 \varepsilon . Y q$ & 11 & 00.07 & 0 & $0 \vee . \wedge 9$ & 11 & شخصية \\
\hline$\varepsilon \varepsilon . V \varepsilon$ & 01 & or.10 & $1 \varepsilon$ & $\varepsilon Y . \wedge T$ & 9 & $0 \leqslant .00$ & 7 & ro.vi & 1. & $\varepsilon \leqslant . \leqslant \varepsilon$ & $\varepsilon$ & $\{r .11$ & $\wedge$ & موضوعية \\
\hline $1 \ldots$ & $11 \varepsilon$ & $1 \ldots$ & r & $1 \ldots$ & r) & $1 \ldots$ & 11 & $1 \ldots$ & rᄉ & $1 \ldots$ & 9 & $1 \ldots$ & 19 & الإجمالي \\
\hline
\end{tabular}

تكرارات ونسب أنواع الصور المستخدمة في المادة الصحفية المقدمة بالصحف.

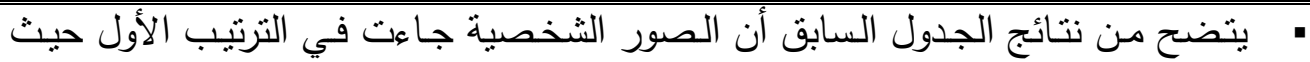

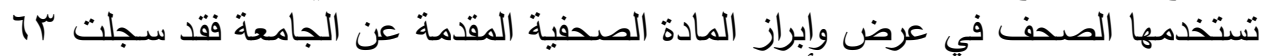

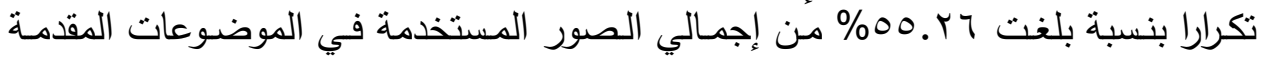
عن الجامعة بالصحف خلال فترة الدراسة، وكانت صحيفة عكاظ أكثر الصحف الصفال استخداما

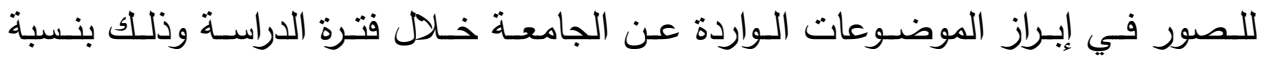

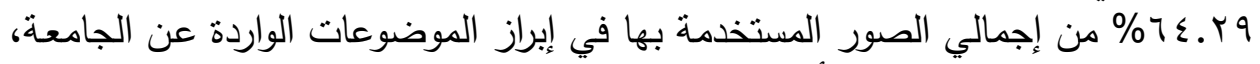

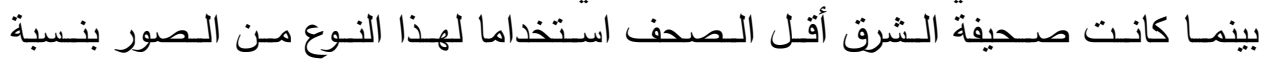
$\% \leqslant 7.10$

وفي الترتيب الثاني جاءت الصور الموضوعية إذ سجلت إه تكرارا بنسبة بلغت

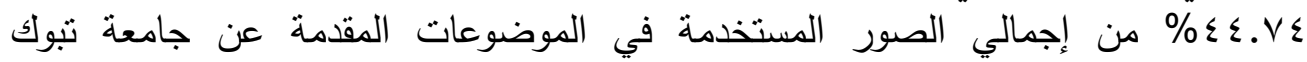

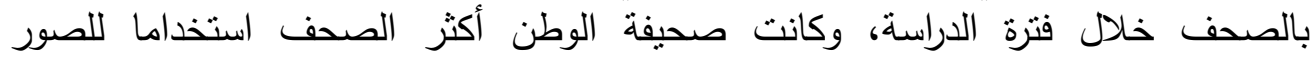

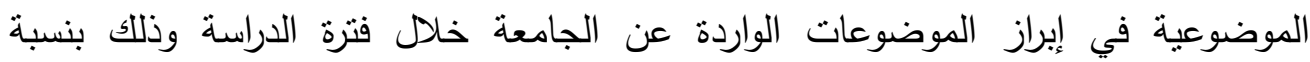

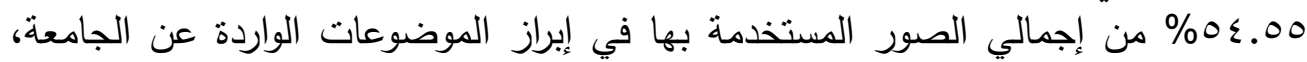

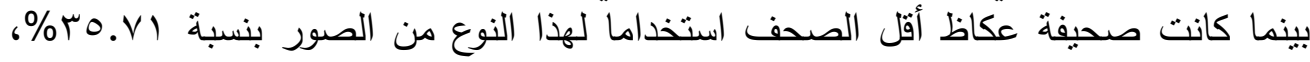

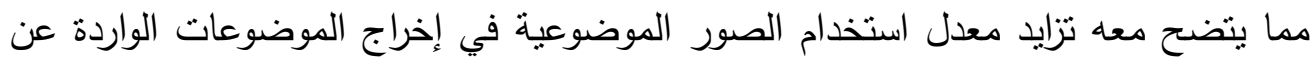
الجامعة بصحيفة الوطن عن باقي الصحف التي شملتها الدراسة. 
مما سبق يتضح أن أغلب صحف الدراسة تهتم بالصور الثخصية أكثر من الصور

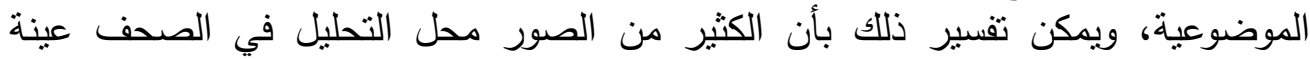

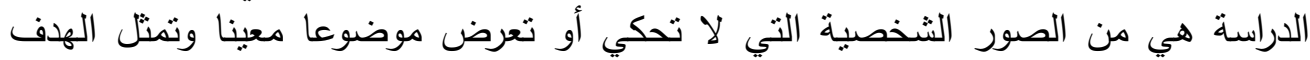

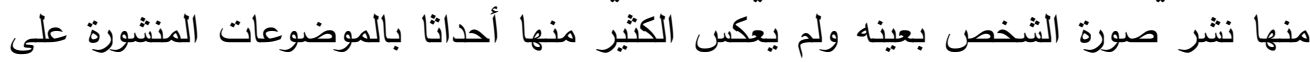

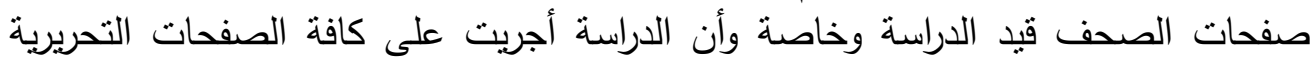

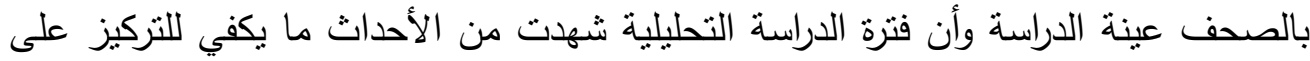

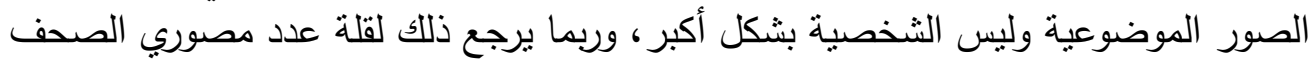

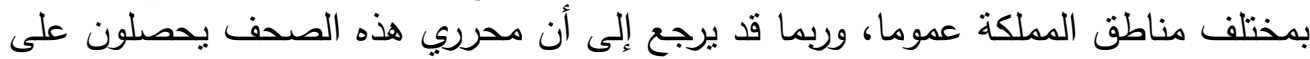

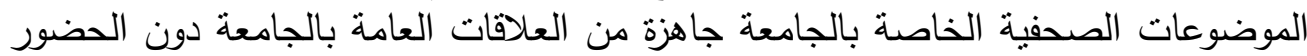
لمقر الحدث محل التغطية. - أنواع الموضوعات الواردة بالمواد التحريرية عن جامعة تبوك .

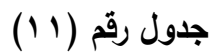

توزيع أنواع الموضوعات الواردة بالمواد التحريرية في الصحف عن جامعة تبوك.

\begin{tabular}{|c|c|c|c|c|c|c|c|c|c|c|c|c|c|c|}
\hline \multicolumn{2}{|c|}{ الإجمالي } & \multicolumn{2}{|c|}{ الشرق } & \multicolumn{2}{|c|}{ الجزيرة } & \multicolumn{2}{|c|}{ الوطن } & \multicolumn{2}{|c|}{ عكاظ } & \multicolumn{2}{|c|}{ المدينة } & \multicolumn{2}{|c|}{ الرياض } & \\
\hline$\%$ & ك & $\%$ & ك5 & $\%$ & 5 & $\%$ & ك & $\%$ & ك & $\%$ & s & $\%$ & ك & \\
\hline 1..or & $r$. & Ir.o. & 7 & $1 \leq . \wedge 1$ & $\wedge$ & $0.1 \mathrm{r}$ & $r$ & $0.9 \mathrm{~V}$ & $\varepsilon$ & 9.71 & $r$ & 10.rr & $v$ & تعليمية \\
\hline$\Lambda . \cdot V$ & $r r$ & A.rr & $\varepsilon$ & Q.Y & 0 & 0.11 & r & 1.97 & 7 & $7 . \leqslant 0$ & $r$ & ^.V. & $\varepsilon$ & بحثية \\
\hline $0 . Y 4$ & 10 & $\varepsilon .1 \mathrm{~V}$ & r & r.V. & r & 1.. & $\varepsilon$ & $\varepsilon . \leqslant \wedge$ & $r$ & r.ru & 1 & T.Or & $r$ & خدمة مجتمع \\
\hline $9.1 \mathrm{r}$ & Y & $1 . . \leqslant r$ & 0 & r.v. & $r$ & $10 . \mathrm{rA}$ & 7 & 1.97 & 7 & 9.71 & $r$ & A.V. & $\varepsilon$ & مؤتمرات وندوات \\
\hline T.rY & 11 & $\varepsilon .1 \mathrm{~V}$ & $r$ & r.v. & r & Ir.Ar & 0 & $0.9 \mathrm{~V}$ & $\varepsilon$ & $7 . \leqslant 0$ & $r$ & $7.0 \%$ & $r$ & قبول \\
\hline Y. $\leqslant Y$ & V & $\varepsilon .1 \mathrm{~V}$ & r & 1.10 & 1 & 0.11 & $r$ & $1 . \leqslant 9$ & 1 & r.rr & 1 & $\cdots$ & . & ابتعاث \\
\hline r.11 & 9 & $\ldots$ & - & r.V. & r & $\ldots$ & . & $\varepsilon . \leqslant \wedge$ & $r$ & $\ldots$ & . & r.IV & 1 & شراكة وتعاون \\
\hline V.rv & YI & $\varepsilon .1 \mathrm{~V}$ & r & V. $\leqslant 1$ & $\varepsilon$ & $0.1 \mathrm{r}$ & r & 1.97 & 7 & 9.71 & $r$ & $\Lambda . \vee$. & $\varepsilon$ & كراسي علمية \\
\hline $1 \leq . V \leq$ & $\leqslant r$ & $1 \leq .01$ & v & $|\leq . \wedge|$ & $\wedge$ & $V .79$ & $r$ & $17 . \leqslant Y$ & 11 & $17.1 \mathrm{r}$ & 0 & IV.rq & $\wedge$ & أنشطة طلابية \\
\hline T.rY & 11 & A.rr & $\varepsilon$ & 0.07 & $r$ & r.07 & 1 & $V . \leqslant 7$ & 0 & $7 . \leqslant 0$ & r & $7.0 Y$ & $r$ & مشروعات وينية \\
\hline 0.71 & 17 & $\varepsilon .1 \mathrm{~V}$ & r & 9.17 & 0 & 8.79 & $r$ & $0.9 \mathrm{~V}$ & $\varepsilon$ & r.r & 1 & r.IV & 1 & اجتماعات دورية \\
\hline 0.97 & iv & T.Y० & $r$ & V. $\leqslant 1$ & $\varepsilon$ & 8.79 & $r$ & r.99 & r & 9.71 & $r$ & s.ro & r & المشاركة في \\
\hline 0.97 & iv & A.rr & $\varepsilon$ & 0.07 & $r$ & 0.11 & $r$ & $0.9 \mathrm{~V}$ & $\varepsilon$ & r.r & 1 & $7.0 Y$ & $r$ & تقويم واعتماد \\
\hline E.YI & ir & 7. & $r$ & 0.07 & $r$ & r.07 & 1 & $\varepsilon . \leqslant \Lambda$ & $r$ & r.r & 1 & r.IV & 1 & تعليم عن بعد \\
\hline 0.97 & iv & $\leq .1 \mathrm{~V}$ & r & r.v. & r & 8.79 & $r$ & $V . \varepsilon 7$ & 0 & 9.71 & $r$ & ט. & $r$ & شكاوى \\
\hline $1 \ldots$ & r^o & $1 \ldots$ & $\leqslant \wedge$ & $1 \ldots$ & $0 \leqslant$ & $1 \ldots$ & rq & $1 \ldots$ & $9 V$ & $1 \ldots$ & ו & $1 \ldots$ & $\leqslant 7$ & الإجمالي \\
\hline
\end{tabular}


يتضح من نتائج الجدول السابق أن الأنشطة الطلابية بالجامعة جاءت في مقدمة أنواع

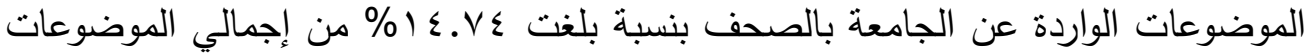
الواردة عن الجامعة بالصحف خلال فترة الدراسة.

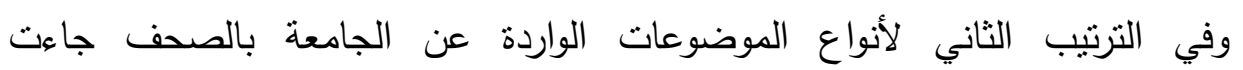

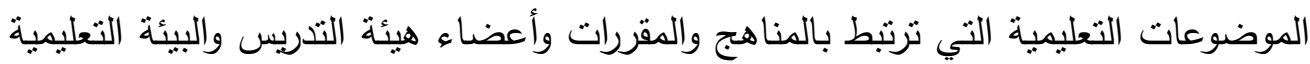

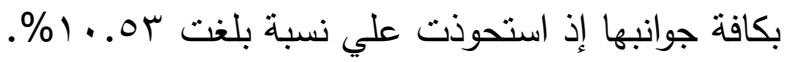

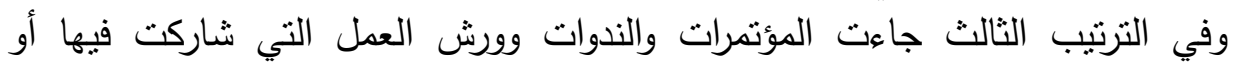

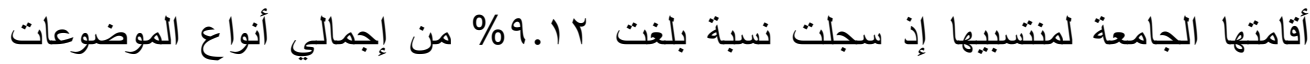

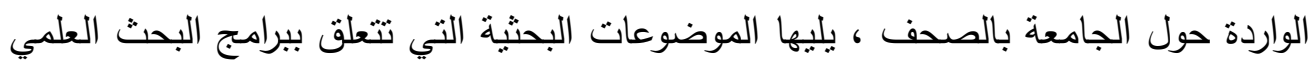

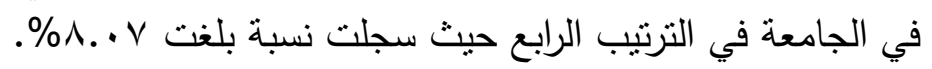

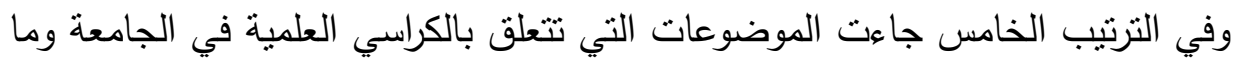

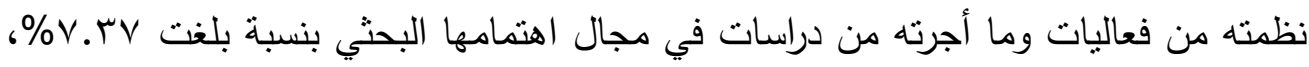

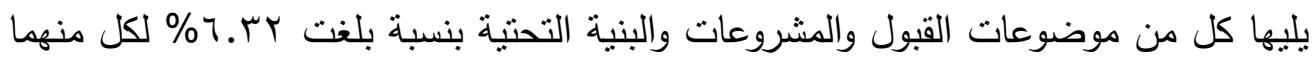

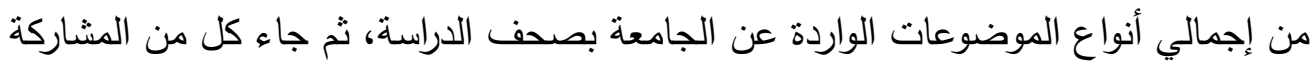

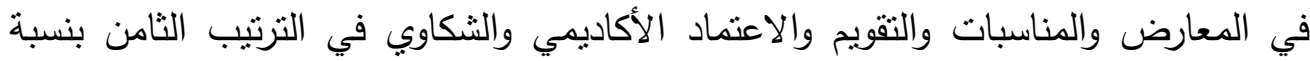
0.97\% لكل منهم على حدة .

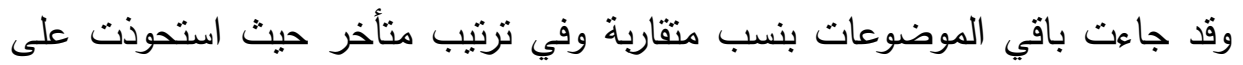

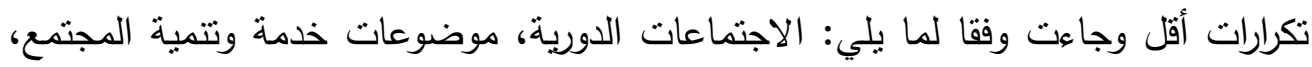

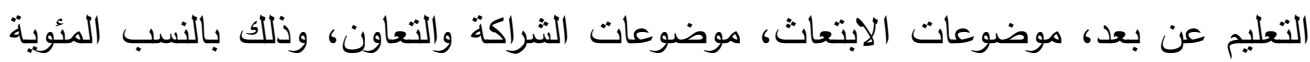

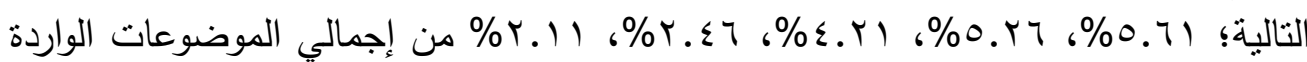
عن الجامعة بصحف الدراسة على الترتيب.

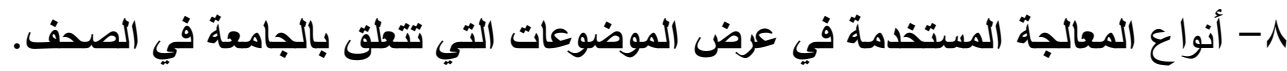

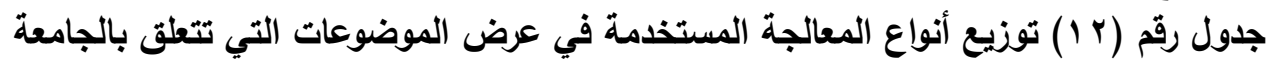
في صحف الاراسة.

\begin{tabular}{|c|c|c|c|c|c|c|c|c|c|c|c|c|c|c|}
\hline \multicolumn{2}{|c|}{ الإجمالي } & \multicolumn{2}{|c|}{ الشرق } & \multicolumn{2}{|c|}{ الجزيرة } & \multicolumn{2}{|c|}{ الوطن } & \multicolumn{2}{|c|}{ عكاظ } & \multicolumn{2}{|c|}{ المدينة } & \multicolumn{2}{|c|}{ الرياض } & \multirow{2}{*}{ نوع المعالمجة } \\
\hline$\%$ & 5 & $\%$ & ك5 & $\%$ & s & $\%$ & s & $\%$ & ك & $\%$ & 5 & $\%$ & 5 & \\
\hline 08.19 & אדו & $07 . Y_{0}$ & TV & $7 \varepsilon . \wedge 1$ & ro & or.10 & Y) & 74.79 & $\varepsilon r$ & $\varepsilon \wedge . q^{\prime}$ & 10 & $0 . .$. & rT & إخباريـة \\
\hline 18.19 & $\varepsilon q$ & 11.20 & 9 & 17.97 & v & IT.AT & 0 & $19 . \varepsilon$. & r & $19 . \% 0$ & 7 & $19.0 \mathrm{~V}$ & 9 & تفسيرية \\
\hline A.VV & ro & אT.r. & $\varepsilon$ & 0.07 & $r$ & 1.. & $\varepsilon$ & $0.9 \mathrm{~V}$ & $\varepsilon$ & 9.71 & $r$ & 10.r & V & توجيهية \\
\hline $1 . . \wedge \Lambda$ & r & $1 . . \leqslant r$ & 0 & 17.97 & v & IT.AT & 0 & 1.97 & 7 & ir.q. & $\varepsilon$ & A. . . & $\varepsilon$ & نقدية \\
\hline 0.97 & iv & T.ro & r & r.V. & $r$ & $1 . . r 7$ & $\varepsilon$ & $r .99$ & r & 9.71 & $r$ & 7.04 & $r$ & دعائية \\
\hline $1 \ldots$ & rNo & $1 \ldots$ & $\varepsilon \wedge$ & $1 \ldots$ & $0 \leqslant$ & $1 \ldots$ & rq & $1 \ldots$ & TV & $1 \ldots$ & M & $1 \ldots$ & $\leq 7$ & الإجمالي \\
\hline
\end{tabular}


يتضح من الجدول السابق أن المعالجة الإخبارية جاءت في مقدمة أنواع المعالجة

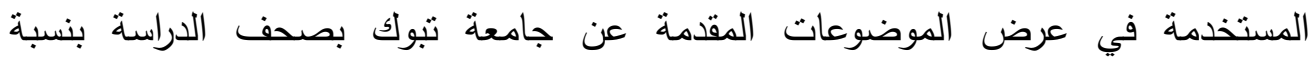

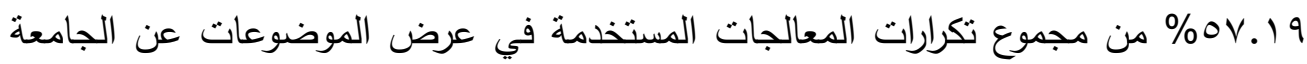

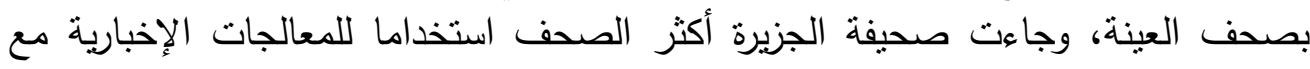

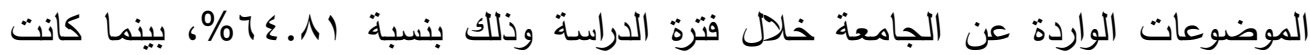

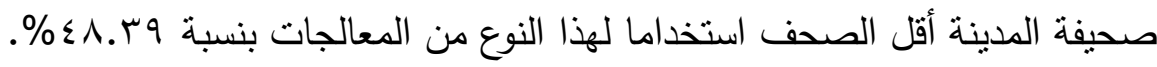

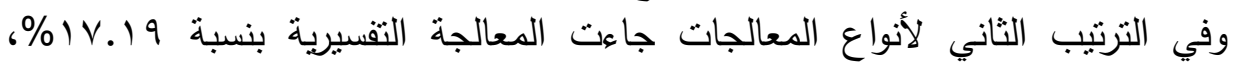

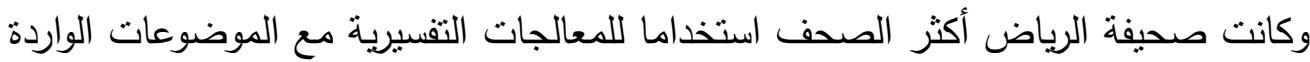

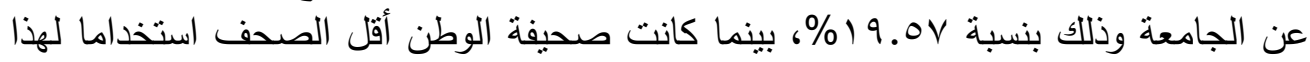

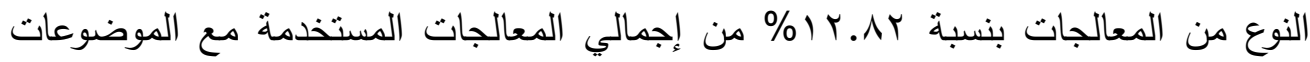

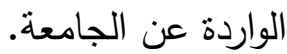

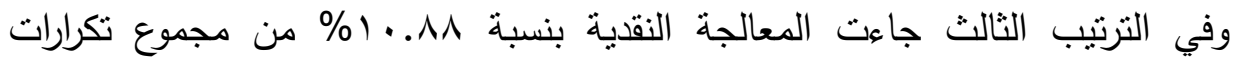

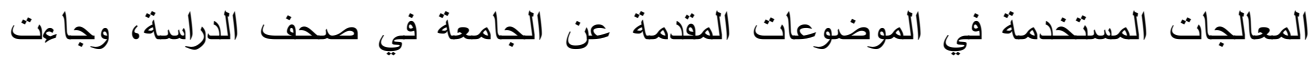

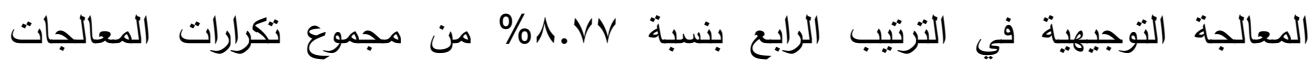
المستخدمة بالموضوعات التحريرية الواردة عن الجامعة في صحف لرفة الدراسة مجتمعة.

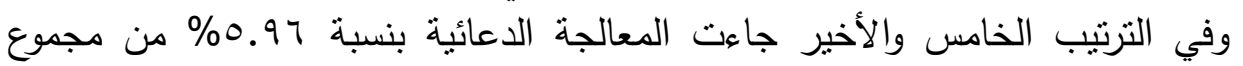
تكرارات المعالجات المستخدمة في الموضوعات الأبرت التحريرية المقدمة عن جامعة تبوك في في صحف الدراسة مجتمعه. ومما سبق نجد أن المعالجات الإخبارية جاءت في المركز الأول من إجمالي تكرارات

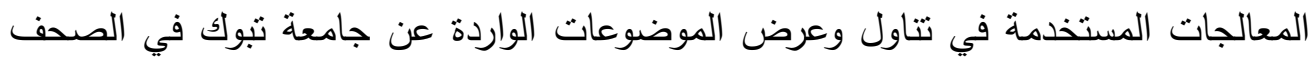

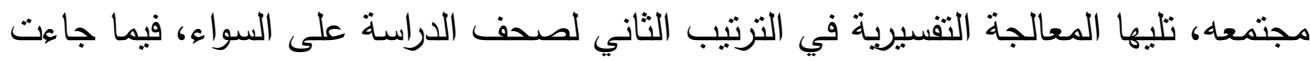

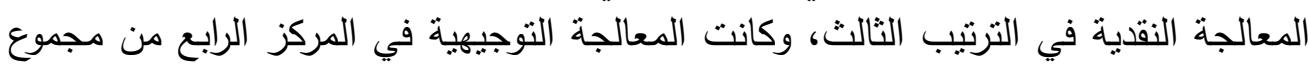

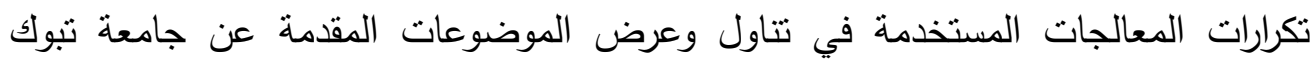
بالصحف مجنمعة. 9- اتجاه الموضوعات الواردة بالصحف نحو الجامعة.

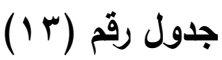

تكرارات ونسب اتجاه الموضوعات الواردة بالصحف نحو الجامعة.

\begin{tabular}{|c|c|c|c|c|c|c|c|c|c|c|c|c|c|c|}
\hline \multicolumn{2}{|c|}{ الإجمالي } & \multicolumn{2}{|c|}{ الشرق } & \multicolumn{2}{|c|}{ الجزيرة } & \multicolumn{2}{|c|}{ الوطن } & \multicolumn{2}{|c|}{ عكاظ } & \multicolumn{2}{|c|}{ المدينة } & \multicolumn{2}{|c|}{ الرياض } & \\
\hline$\%$ & ك & $\%$ & ك & $\%$ & ك & $\%$ & ك & $\%$ & ك & $\%$ & ك5 & $\%$ & ك & \\
\hline$\uparrow \Lambda . \leqslant Y$ & 190 & VY.qY & ro & $v . . r v$ & rs & Y & ד r & 78.17 & $\leq 0$ & $T \leq .0 Y$ & $r$. & TV.rq & r & إيجابي \\
\hline$r \leq . Y$ & 79 & rr.qr & 11 & $r \leqslant . . V$ & ir & $r r . . \Lambda$ & 9 & ro.rv & iv & ro.Al & $\wedge$ & rr.qu & 11 & محايا \\
\hline V.rv & r & $\{.1 V$ & $r$ & 0.01 & $r$ & 1..r & $\varepsilon$ & V. $\leqslant 4$ & 。 & 9.71 & $r$ & A.v. & $\varepsilon$ & سلبي \\
\hline $1 \ldots$ & rAo & $1 \ldots$ & $\leqslant 1$ & $1 \ldots$ & \& & $1 \ldots$ & $r q$ & $1 \ldots$ & IV & $1 \ldots$ & $\mu_{1}$ & $1 \ldots$ & « & الإجمالي \\
\hline
\end{tabular}


يتضح من الجدول السابق أن الاتجاه الإيجابي نحو الجامعة جاء في مقدمة اتجاه

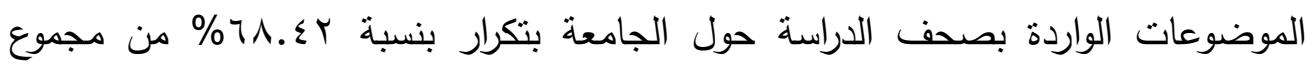

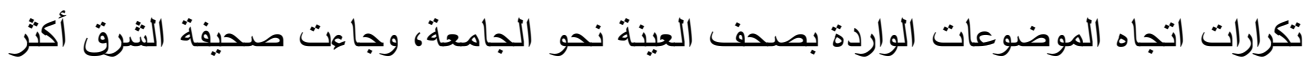

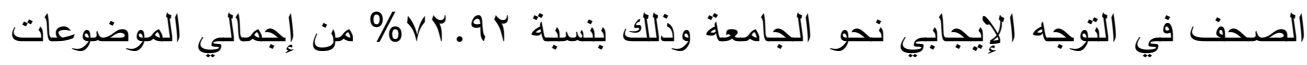
المنشورة بها عن الجامعة، بينما كانت صحيفة المدينة أقل الصحف في التوجه الإيجابي نحو

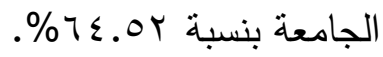

وفي الترتيب الثاني لاتجاه الموضوعات الواردة بالصحف نحو الجامعة جاء الاتجاه

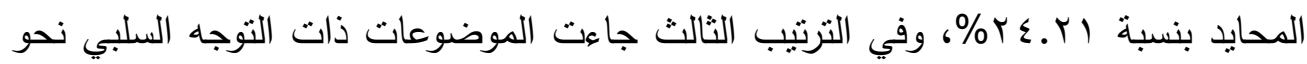
الجامعة وذلك بنسبة r. مV. من إجمالي تكرارات اتجاه الموضوعات الواردة بصحف العينة نحو الجامعة، وجاءت صحيفة الوطن أكثر الصحف في التوجه السلبي نحو الجامعة وذلك بنسبة צr.. (\% من إجمالي الموضوعات المنشورة بها عن الجامعة، بينما كانت صحيفة

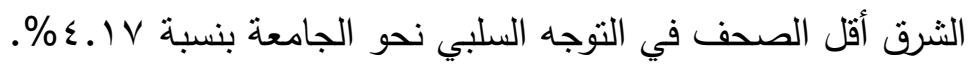
• 1 - الصورة العامة للجامعة في الموضوعات الواردة عنها بالصحف عينة الدراسة.

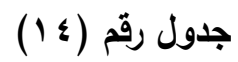

تكرارات ونسب الصورة العامة للجامعة في الموضوعات الواردة عنها بالصحف.

\begin{tabular}{|c|c|c|c|c|c|c|c|c|c|c|c|c|c|c|}
\hline \multicolumn{2}{|c|}{ الإجمالي } & \multicolumn{2}{|c|}{ الشرق } & \multicolumn{2}{|c|}{ الجزيرة } & \multicolumn{2}{|c|}{ الوطن } & \multicolumn{2}{|c|}{ عكاظ } & \multicolumn{2}{|c|}{ المدينة } & \multicolumn{2}{|c|}{ الرياض } & الصحيفة \\
\hline$\%$ & ك & $\%$ & ك & $\%$ & ك & $\%$ & ك & $\%$ & ك & $\%$ & ك & $\%$ & ك & الصورة العامة \\
\hline ri.vo & ir & ro... & ir & rV.VA & 10 & $r . .01$ & $\wedge$ & $17 . \leqslant 4$ & 11 & Yr.ON & $v$ & $19.0 \mathrm{~V}$ & 9 & تؤدي دورها بكفاعة \\
\hline rะ.rq & $9 \wedge$ & $r 0 . \leqslant r$ & iv & איז.rr & 11 & YA.YI & 11 & $r \varepsilon . r r$ & rr & rn.vi & ir & r..97 & iv & مؤسسة ذات أداء \\
\hline$r . .11$ & $\wedge 4$ & rq.1V & $1 \leq$ & rq.7r & 17 & rr.rr & ir & ro.Ar & $r \varepsilon$ & 19.40 & 7 & rA. YY & ir & مؤسسة ذات أداء \\
\hline$\Lambda . \leqslant r$ & $r \varepsilon$ & A.rr & $\varepsilon$ & 0.04 & $r$ & $1 . .97$ & $\varepsilon$ & V. $\leqslant 4$ & • & 9.71 & $r$ & $1 . . \wedge V$ & ○ & مؤسسة ذات أداء \\
\hline $0 . Y^{4}$ & 10 & r.. & 1 & r.v. & $r$ & 8.79 & $r$ & $0.9 V$ & $\varepsilon$ & 9.71 & $r$ & \&.ro & $r$ & مؤسسة ذات أداء \\
\hline $1 \ldots$ & r^o & $1 \ldots$ & $\leqslant \wedge$ & $1 \ldots$ & $0 \leqslant$ & $1 \ldots$ & rq & $1 \ldots$ & iv & $1 \ldots$ & m & $1 \ldots$ & $\leqslant 7$ & الإجمالي \\
\hline
\end{tabular}

يتضح من الجدول السابق أن صورة العامة لجامعة تبوك في الموضوعات الواردة عنها

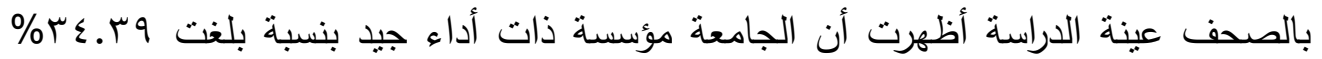


من إجمالي من ورد بالصحف حول الجامعة من موضوعات، وجاءت صحيفة المدينة أكثر

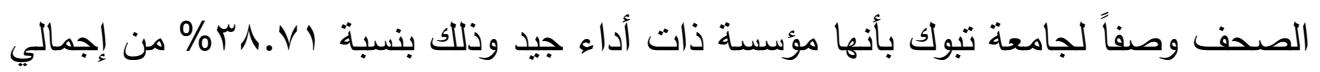

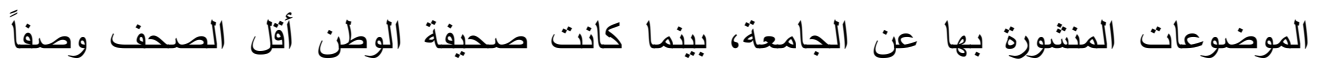

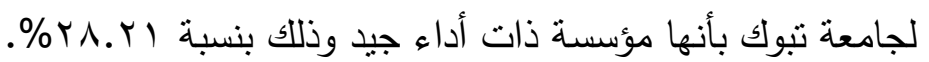
وفي الترتيب الثاني لأنواع الصورة العامة لجامعة تبوك كما تتاولتها صحف العينة جاء

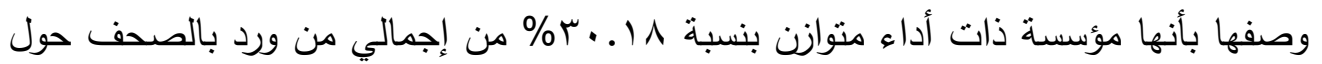
الجامعة من موضوعات، وجاءت صحيفة عكاظ أكثر الصحف وصفاً لجامعة ثبوك بأنها

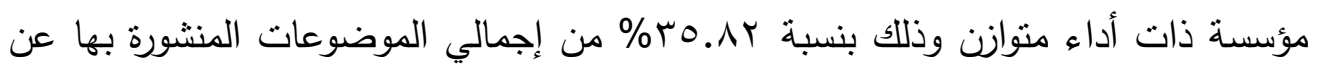
الجامعة، بينما كانت صحيفة الرياض أقل الصحف وصفاً لجامعة تبوك بأنها مؤسسة ذات

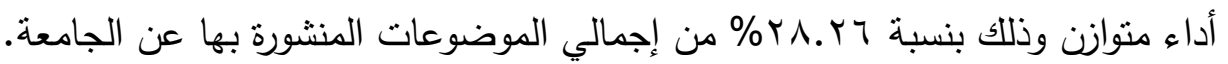
وفي الترتيب الثالث أظهرت الموضوعات الواردة عن الجامعة بالصحف أنها تؤدي أدوارها بكفاءة عالية وذللك بنسبة V0. V. 1. من إجمالي من ورد بالصحف حول الجامعة من

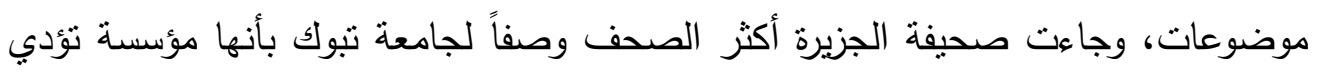

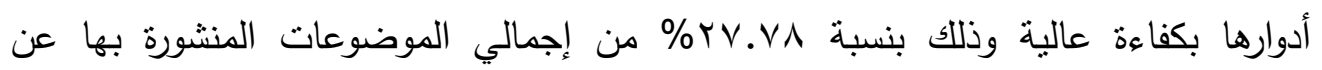
الجامعة، بينما كانت صحيفة عكاظ أقل الصحف وصفاً للجامعة بأنها تؤدي أدوارها بكفاءة

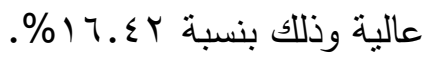

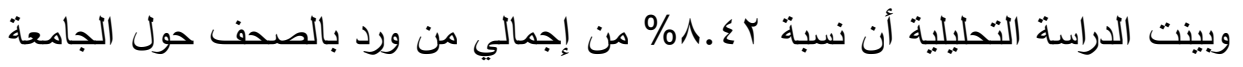

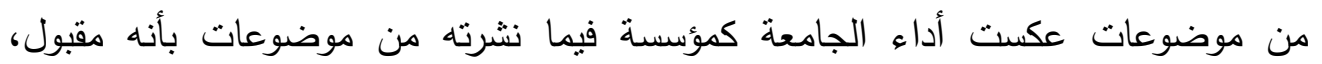

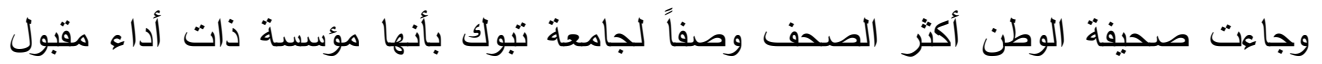
وذللك بنسبة بr. • (\% من إجمالي الموضوعات المنشورة بها عن الجامعة، بينما كانت صحيفة الجزيرة أقل الصحف وصفاً لجامعة تبوك بأنها مؤسسة ذات أداء مقبول وذللك بنسبة 0.07\% من إجمالي الموضوعات المنشورة بها عن الجامعة. وفي الترتيب الأخيرة للصورة العامة لجامعة تبوك كما أظهرتها الموضوعات الونهوة الواردة عنها

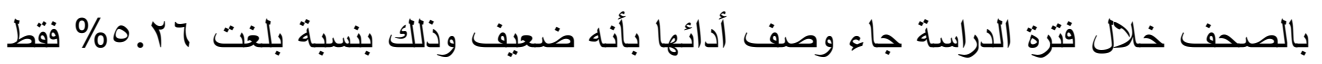
من إجمالي من ورد بالصحف حول الجامعة من موضوعات، وكانت صحيفة المدينة أكثر

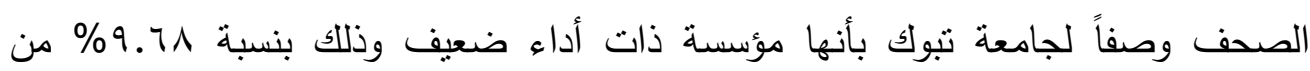

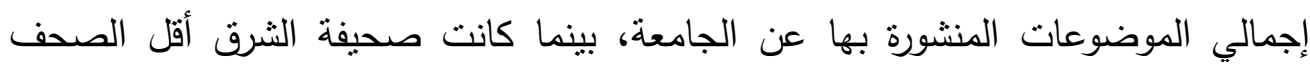


وصفاً لأداء الجامعة بأنه ضعيف وذللك بنسبة م . . \% من إجمالي الموضوعات المنشورة بها عن الجامعة. نتائج الدراسة الميدانية:

ا. مدى انتظام المبحوثين في قراءة الصحف السعودية . جدول رقم (0 10 ) تكرارات ونسب مدى انتظام المبحوثين في قراءة الصحف السعودية

\begin{tabular}{|c|c|c|}
\hline$\%$ & ك5 & مدى الانتظام في قراءة الصحف \\
\hline$r \leq .1$ & or & دائما \\
\hline ז. & $V \varepsilon$ & أحيانا \\
\hline 11.1 & r & نادرا \\
\hline$r . .0$ & IV & ע \\
\hline $1 \ldots$ & $r r$. & المجموع \\
\hline
\end{tabular}

تشير نتائج الجدول السابق إلى أن نسبة من يقرعون الصحف السعودية اليومية بلغت

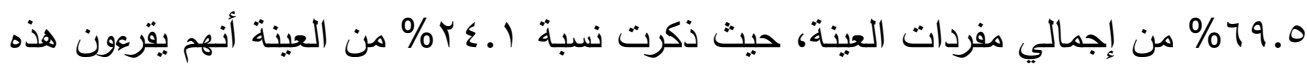
الصحف بصفة دائمة، بينما ذكرت نسبة ج.بr\% من العينة أنهم يقرعون هذه الصحف لهن

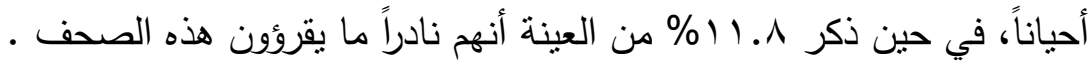

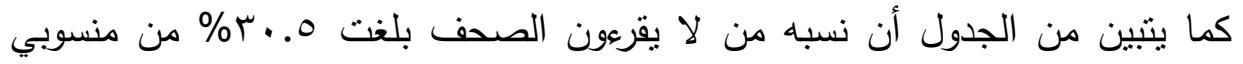

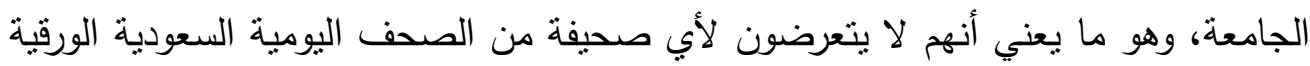

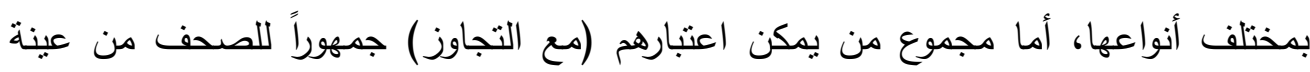

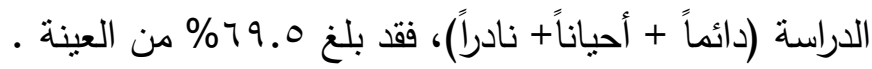
وهذه النتيجة ندل علي تراجع معدلات قراءة الصحف من قبل أعضاء هيئة التدريس وموظفي الجامعة باعتبارهم من الصفوة، وقد يرجع ذلك إلي ظهور وسائل اتصال حديثة جذبت إليها مختلف الفئات من الجمهور بالمجتمع السعودي وبمعدلات تعرض عالية، منها القنوات الفضائية التليفزيونية، والانترنت، وكذلك الجوالات وما تتضمنه من برامج متعددة

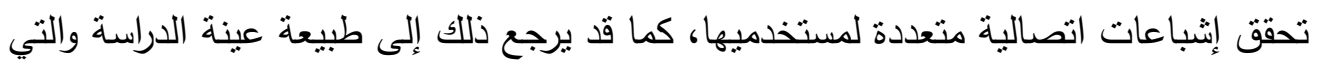
تضم نسبة كبيرة من المغتربين الذين يعملون بالجامعة كأعضاء لهيئة التدريس وليس لديهم

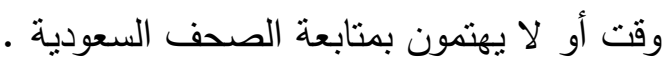


r. مدى اهتمام المبحوثين بمتابعة الأخبار والموضوعات التي تنشر عن جامعة تبوك في الصحف . مأ جلول رقم (7 1 ) توزيع مدى اهتمام المبحوثين بمتابعة الأخبار والموضوعات التي تنثر عن

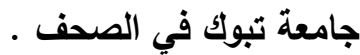

\begin{tabular}{|c|c|c|}
\hline$\%$ & كs & مدى الاهتمام بمتابعة أخبار الجامعة \\
\hline$\varepsilon$ ४.० & 70 & نعم \\
\hline$\leqslant 0.1$ & 79 & 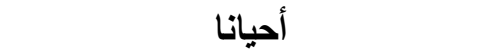 \\
\hline IY. & 19 & $\gamma$ \\
\hline $1 \ldots$ & 10r & المجموع \\
\hline
\end{tabular}

• يتضح مـن خـلاص الجدول السابق أن غالبيـة مـن يقرؤن الصحف مـن العينـة يهتمـون بمتابعة الأخبار والموضوعات التي تتشر عن جامعة تبوك في الصحف السعودية اليومية

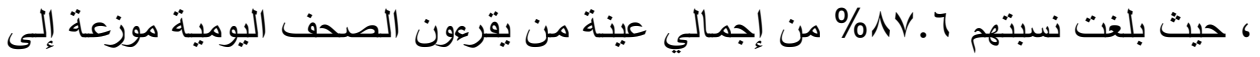

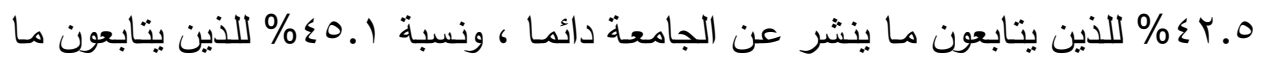
ينشر عن الجامعة من أخبار وموضوعات أحيانا.

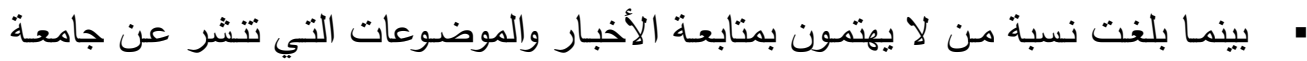
تبوك في الصحف اليومية ـ. r ا \% من إجمالي العينة لمن يقرعون الصحف. r. درجة اهتمام المبحوثين بمتابعة أخبار الجامعة في الصحف السعودية . .

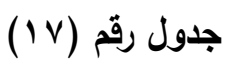

توزيع درجة اهتمام المبحوثين بمتابعة أخبار الجامعة في الصحف السعودية.

\begin{tabular}{|c|c|c|}
\hline$\%$ & كs & درجة الاهتمام بمتابعة أخبار الجامعة بالصحف \\
\hline rr. & $\varepsilon r$ & أهتم جلا \\
\hline rq. & or & أهتم بدرجة متوسطة \\
\hline r^.乏 & $\mu$ & قليلاً ما أهتم \\
\hline $1 \ldots$ & צ & 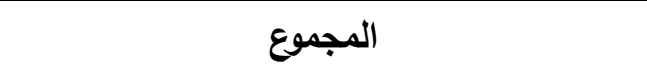 \\
\hline
\end{tabular}


• يتضح من نتائج الجدول السابق أن نسبة ا.بr\% مـن إجمـالي من يتابعون الأخبار والموضوعات الخاصة بالجامعة في الصحف يهتمون جدا بتلك المتابعة اويحرصون عليها ، كما يتبين أن نسبة الذين يهتمون بمتابعة هذه الموضوعات والأخبار عن الجامعة بدرجة

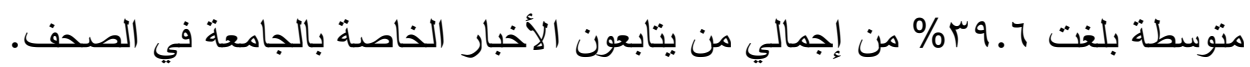

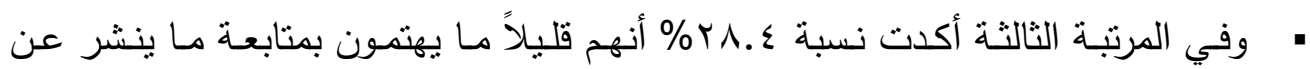
الجامعة التي ينتسبون إليها في الصحف ضدن ما يقرؤونـه من موضـوعات ومضامين

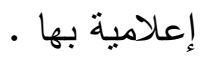

؛ ـ مصادر حصول المبحوثين علي الأخبار والمعلومات التي تتعلق بالجامعة . جدول رقم (1) إنتيب مصادر حصول المبحوثين علي الأخبار والمعلومات التي تتعلق بالجامعة.

\begin{tabular}{|c|c|c|c|c|c|c|c|c|c|c|}
\hline \multicolumn{2}{|c|}{ الوزن المرجح } & \multirow{2}{*}{$\sqrt{3}$} & \multirow{2}{*}{$\overline{3}$} & \multirow{2}{*}{$\frac{\overline{3}}{3}$} & \multirow{2}{*}{ 牙 } & \multirow{2}{*}{$\overline{3}$} & \multirow{2}{*}{ 勇 } & \multirow[b]{2}{*}{$\sqrt{3}$} & \multirow{2}{*}{. } & \multirow{2}{*}{ الترتيب } \\
\hline المئوي & النقاط & & & & & & & & & \\
\hline $1 \% .9$ & צץ & $\varepsilon$ & . & r & $1 \varepsilon$ & iv & rr & $v$ & 11 & الصحف السعودية \\
\hline $0 . r$ & iv. & . & 8 & $r$ & . & ir & $r$ & $r$ & 7 & الإذاعة السعودية \\
\hline r.r & V4 & r & r & . & $\varepsilon$ & . & $\varepsilon$ & $r$ & $r$ & قتوات التليفزيون السعودي \\
\hline ro.r & Arr & . & . & . & r & $\varepsilon$ & 10 & r. & זי & شبكة الانترنت \\
\hline Ir.r & $\leq .0$ & . & . & 11 & $\wedge$ & 7 & r & rr & $r$ & الانترنع الجامعة على شبكة \\
\hline ^.. & Tr & . & . & . & 9 & 9 & $1 \varepsilon$ & $1 \leqslant$ & . & صحيفة أخبار الجامعة \\
\hline rv.o & 9.0 & . & r & · & 1 & $\bullet$ & IV & $0 \leqslant$ & $\leqslant 9$ & الاتصال الثخصي \\
\hline 7.0 & r! & . & . & . & $\varepsilon$ & r. & $1 \varepsilon$ & r & . & جوال الجامعة \\
\hline \multicolumn{2}{|r|}{ rral } & & & & & & & & & مجموع الأوزان \\
\hline
\end{tabular}

تدل بيانات الجدول السابق علي أن ترتيب مصادر حصول المبحوثين علي الأخبار والمعلومات التي تتعلق بالجامعة جاء وفقا لما أحرزته من تكرارات وأوزان نسبية كما يلي:

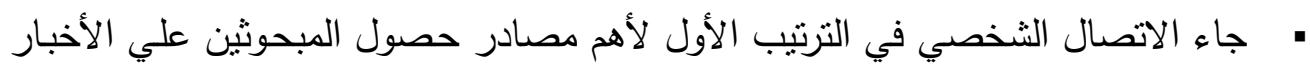

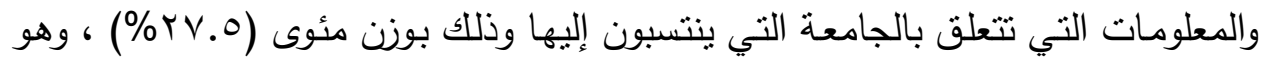

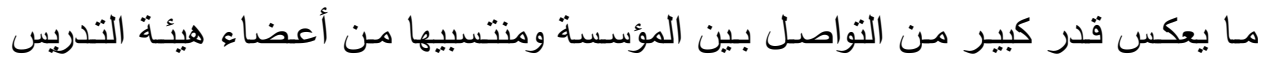


والموظفين ، كما يدل على مرونـة العمليات الاتصالية التي تتم بين المؤسسة وجمهورها

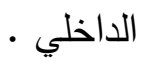

• وفي الترتيب الثاني لأهم مصادر حصول المبحوثين علي الأخبار والمعلومات التي تتعلق بالجامعة جاءت شبكة الإنترنت وما تتضمنه من مواقع اتصالية وإخبارية وغيرها بالإضافة

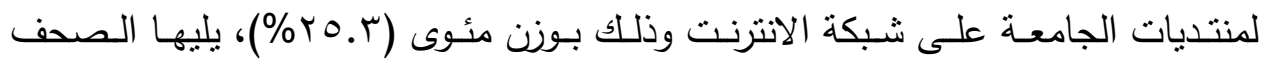
السعودية المختلفة في الترتيب الثالث ضـن مصنادر حصول المبحوثين علي الأخبار والمعلومات التي تتعلق بالجامعة وذلك بوزن مئوى (9. ( ) \%).

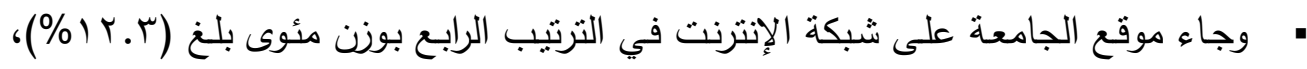
يليه صحيفة أخبار الجامعة في الترتيب الخامس ضمن مصادر حصول المبحوثين علي لإنرني

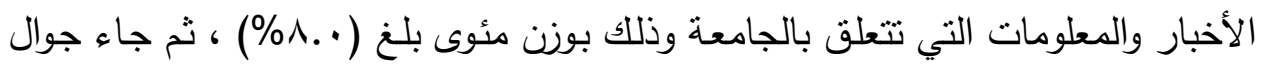

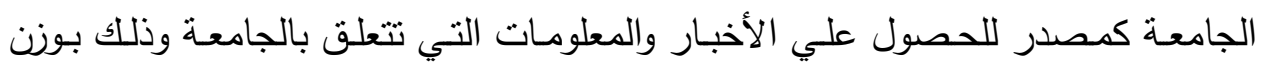

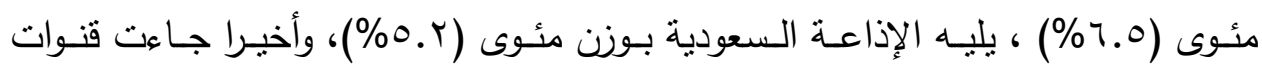

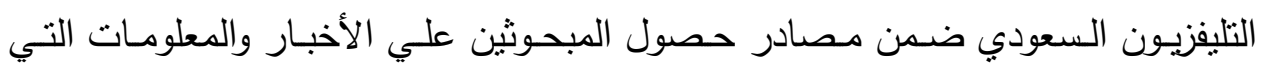

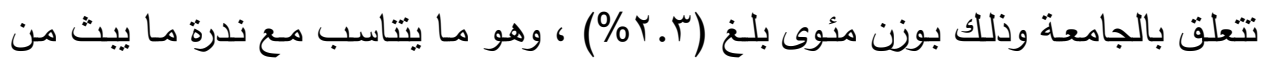
أخبار ومضامين إعلامية عن الجامعة بالتلافزيون بقنواته المختلفة. ه. آراء المبحوثين في ملامح الصورة التي تقدمها الصحف السعودية عن جامعة بأنة تبوك . جدول رقم (9 1 ) توزيع آراء المبحوثين في ملامح الصورة التي تقدمها الصحف السعودية عن جامعة تبوك.

\begin{tabular}{|c|c|c|}
\hline$\%$ & ك & آراء المبحوثين في ملامح صورة الجامعة بالصحف \\
\hline ه9.V & $\wedge$. & الصورة التي تقدهها الصحف عن الجامعة صورة إيجابية \\
\hline 10.V & $r_{1}$ & الصورة التي تقامها الصحف عن الجامعة صورة سلبية \\
\hline$r \leqslant .7$ & r & تجمع بين الملامح الايجابية والسلبية \\
\hline $1 \ldots$ & ع זו & 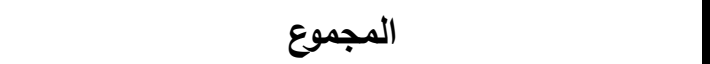 \\
\hline
\end{tabular}

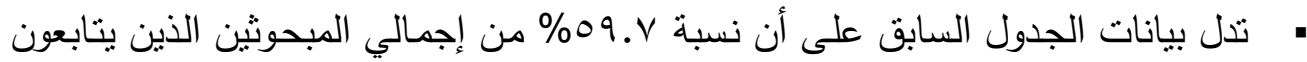

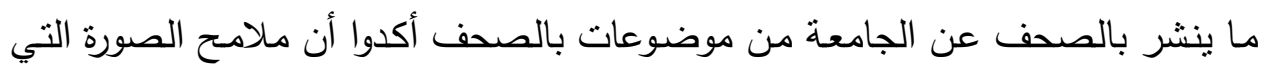


تقدمها الصحف عن الجامعـة إيجابيـة ، بينمـا ترى نسبة 7. ؟ ؟ \% مـن إجمـالي الذين يتابعون مـا ينشر بالصحف عن الجامعة أن الصورة لتي تقدمها الصحف عن الجامعة تجمع بين الملامح الايجابية والسلبية.

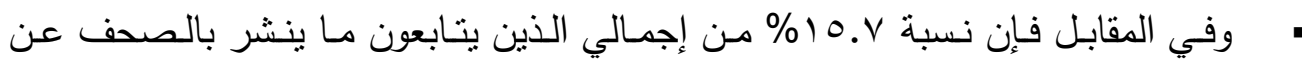
الجامعة يرون أن الصورة التي تقدمها الصحف عن الجامعة سلبية . צ- أبرز الملامح الإيجابية لصورة الجامعة التي تعرضها الصحف بالمملكة من وجهة نظر العاملين بالجامعة .

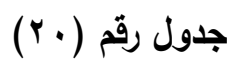

تكرارات ونسب الملامح الإيجابية لصورة الجامعة التي تعرضها الصحف بالمملكة من وجهة نظر العاملين بالجامعة.

\begin{tabular}{|c|c|c|}
\hline$\%$ & ك & ـ الملامح الإيجابية لصورة الجامعة بالصحف \\
\hline Ir.r & 10 & مؤسسة بحثية تهتم بقضايا المنطقة والمجتمع \\
\hline$\leq \vee . \wedge$ & $0 \leqslant$ & مؤسسة تمتثلك بنية تحتية مناسبة \\
\hline ץ^.r & rr & تستقطب أعضاء هيئة تدريس أكفاء ومتميزين \\
\hline r.. r & $r \leq$ & توفر حزمة من الخدمات المتميزة لمنسوبيها \\
\hline $1 \leq . r$ & 17 & توفر الجامعة الأنشطة الطلابية المناسبة \\
\hline$\wedge . \wedge$ & $1 \cdot$ & ل لديها معايير واضحة للأداء \\
\hline$\leqslant 0.1$ & 01 & تقدم تعليم نوعي يواكب منطلبات سوق العمل \\
\hline 19.0 & rr & مؤسسة تخدم مجتمعها وتسعى لتنميته \\
\hline r^.r & rr & تهتم بالحصول على الاعتماد لبرامجها التعليمية \\
\hline$r \leq .0$ & rq & تمتلك برامج لتطوير مهارات منسوييها \\
\hline \multicolumn{2}{|c|}{$11 \%$} & \\
\hline
\end{tabular}

تدل بيانات الجدول السابق علي مجموعة من النتائج أهمها :

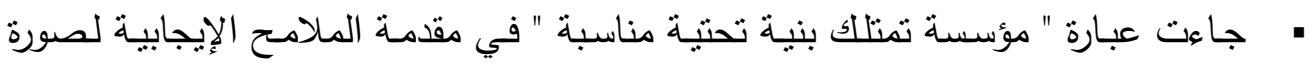
الجامعة التي تعرضهها الصحف بالمملكة من وجهة نظر العاملين بالجامعة وذلك بنسبة

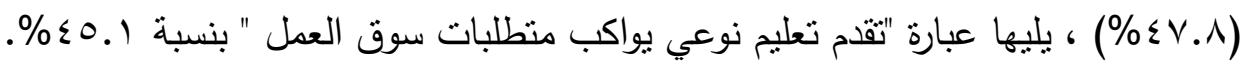


• وفي الترتيب الثالث للملامسح الإيجابية لصورة الجامعة التي تعرضها الصحف بالمملكة

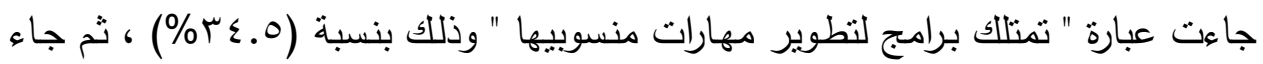

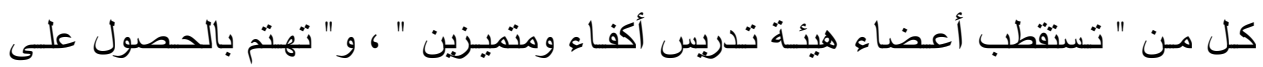

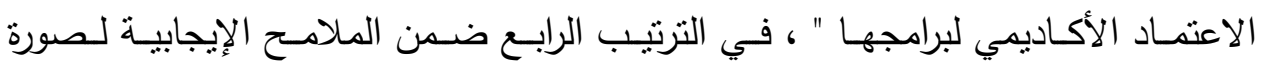

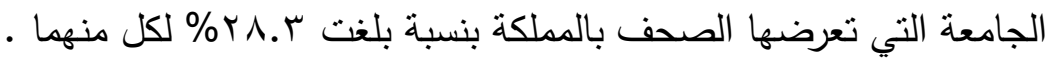

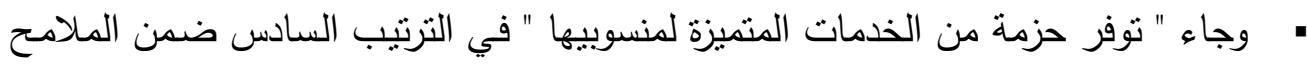

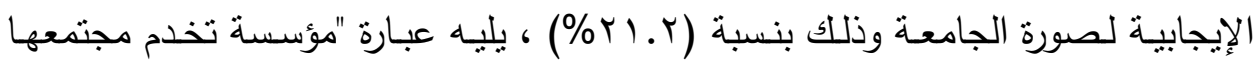

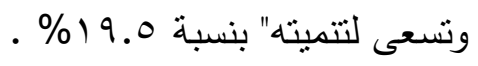

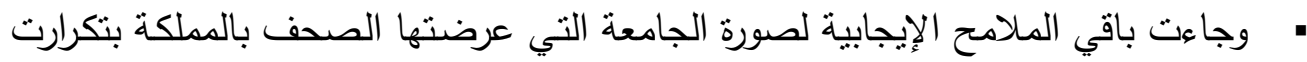

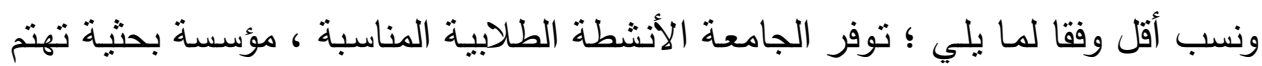

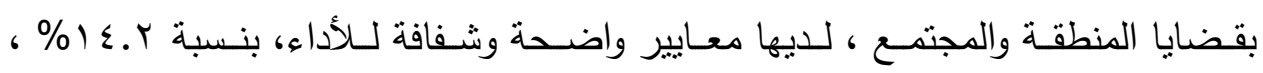

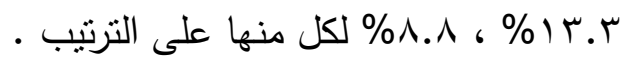

V - أبرز الملامح السلبية لصورة الجامعة التي تعرضها الصحف بالمملكة من وجهة نظر العاملين بالجامعة .

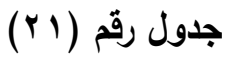

تكرارات ونسب الملامح السلبية لصورة الجامعة التي تعرضها الصحف بالمملكة من وجهة نظر العاملين بالجامعة.

\begin{tabular}{|c|c|c|}
\hline$\%$ & ك & الملامح السلبية لصورة الجامعة بالصحف \\
\hline rv.. & r. & لا تستوعب احتياجات المنطقة التعليمية \\
\hline $1 \leq .1$ & $\wedge$ & النقص في برامج خدمة المجتمع وتنميته \\
\hline Ir.e & $\mathrm{v}$ & لا تهتم بقضايا المنطقة والمجتمع \\
\hline 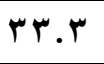 & 11 & ضعف جودة الخدمة التعليمية ببرامجها التعليمية \\
\hline 19.8 & 9 & قلة أعضاء هيئة التدريس المتميزين بها \\
\hline r^.9 & Y & النقص في بنيتها التحتية ومرافقها المساندة \\
\hline $9 . r$ & 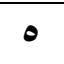 & غياب المعايير الواضحة لتقييم الأداء \\
\hline rV.A & 10 & برامجها التعليمية لا تواكب متطلبات سوق العمل \\
\hline$r \wedge .9$ & Y & لا تهتم بالزرضا الوظيفي لمنسوييها \\
\hline r.v & $r$ & لا توفز برامج تدريبية لكافة لمنسوييها \\
\hline \multicolumn{2}{|c|}{$0 \leqslant$} & الإجمالي \\
\hline
\end{tabular}


• توضح بيانات الجدول السابق أن كل من عبارتي " نقص بنيتها التحتية ومرافقها المساندة

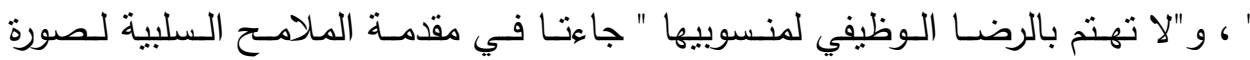
الجامعة التي تعرضـها الصحف بالمملكة من وجهة نظر العاملين بالجامعة وذلك بنسبة

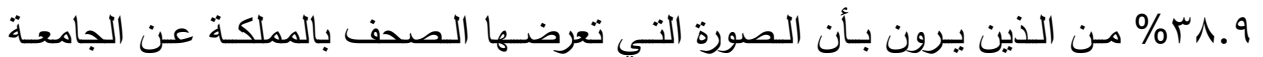
تتضمن ملامح سلبية.

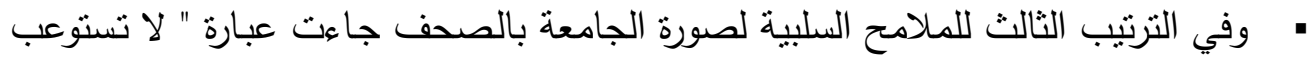

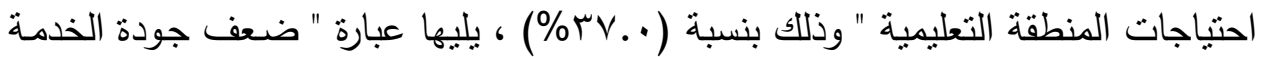

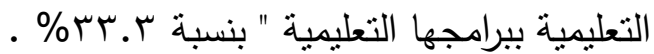
وفي الترتيب الخامس للمامسح السلبية لصورة الجامعة التي تعرضها الصحف بالمملكة جاءت عبارة " برامجها التعليمية لا تواكب متطلبات سوق العمل " بنسبة بلغت ArV.

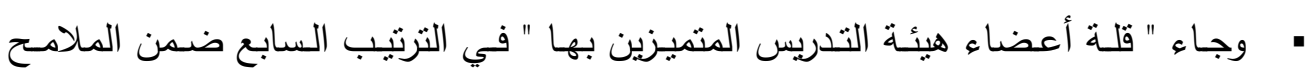

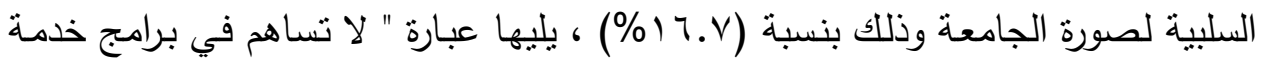

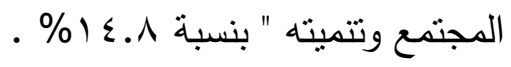

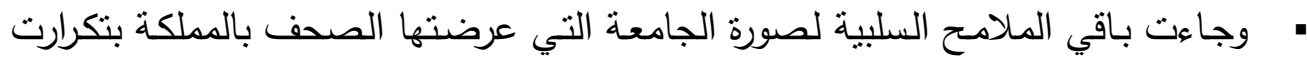

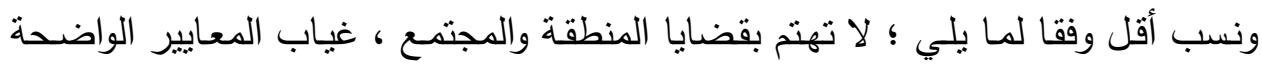

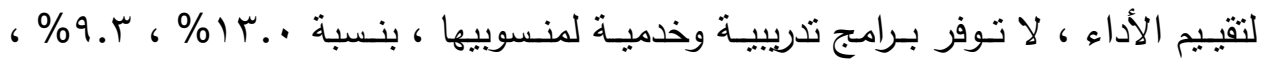

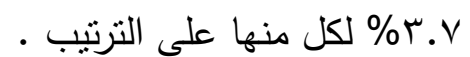
1 - مدى اقتناع العاملين بالجامعة بواقعية الصورة المقدمة عنها بالصحف.

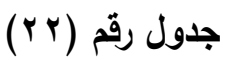

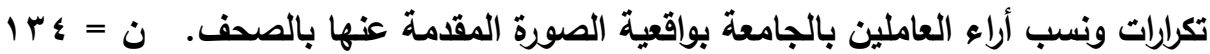

\begin{tabular}{|c|c|c|}
\hline \multicolumn{2}{|c|}{ الوزن المرجح } & \multirow{2}{*}{ اقتناع العاملين بالجامعة بواقعية الصورة المقدمة عنها بالصحف. } \\
\hline الوزن المئوي & 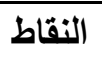 & \\
\hline IT.YY & rrt & تعرض الصحف جوانب مهمة من الحياة الواقعية داخل الجامعة . \\
\hline IV.rY & 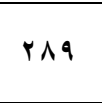 & تاقدم الصحف نماذج لثخصيات العاملين بالجامعة في أدوار تتفق مع أدوارهم في \\
\hline 14.19 & $r \cdot \leq$ & معظم الصحف تقدم صوراً صحيحة ومنطابقة مع واقع الحياة الجامعية. \\
\hline $19 . \leqslant 1$ & rro & تتشابه المكانة الاجتماعية التي تظهرها الصحف للجامعة مع مكانتها في الواقع. \\
\hline $11.9 \leq$ & miv & الواقع • تثشابه سلوكيات منتسبي الجامعة التي تنشر بالصحف مع سلوكياتهم الفعلية في \\
\hline $11.9 \leq$ & M IV & تتشاجهابه المشكلات التي تواجه منسويي الجامعة في الصحف مع المشكلات التي \\
\hline \multicolumn{2}{|c|}{$17 V \varepsilon$} & مجموع الأوزان \\
\hline
\end{tabular}


• تلدل بيانات الجدول السابق علي النتائج التالية :

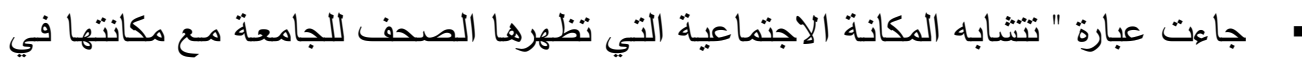

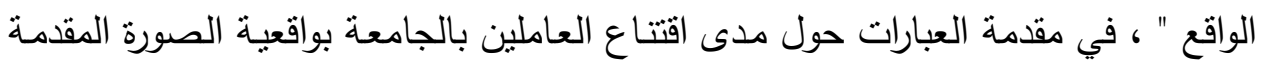

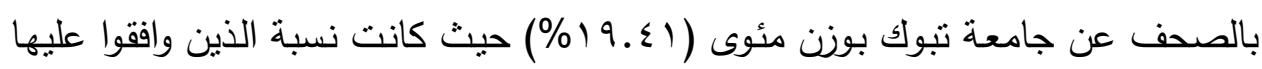

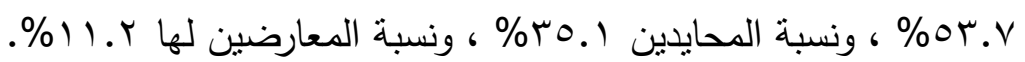

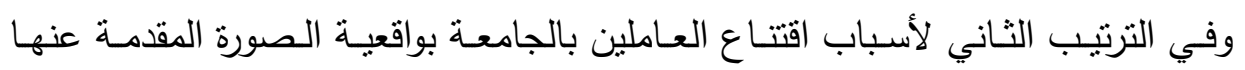

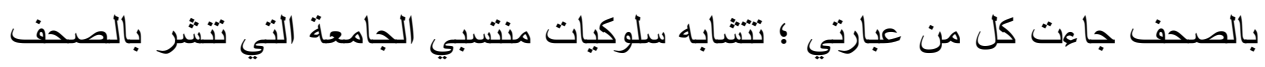

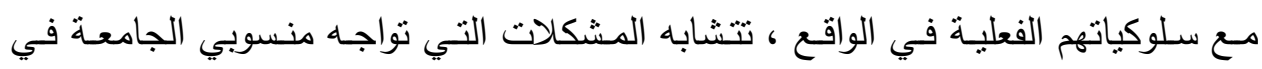

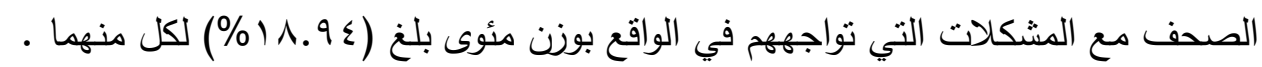

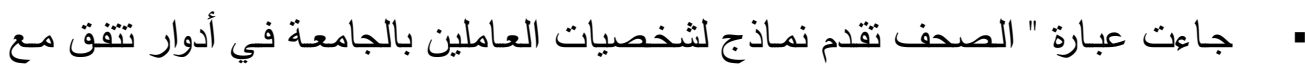

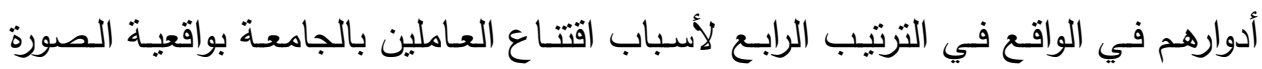

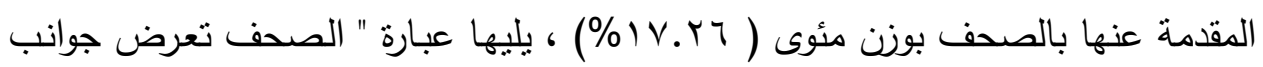

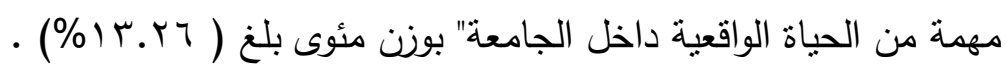

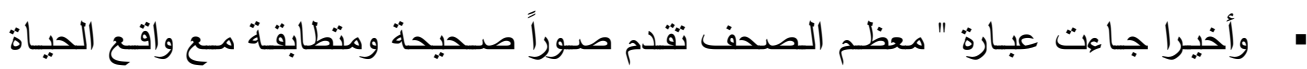

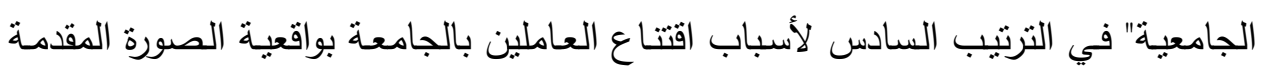

$$
\text { عنها بالصحف بوزن مئوى ( } 10.70 \text { (1\%). }
$$

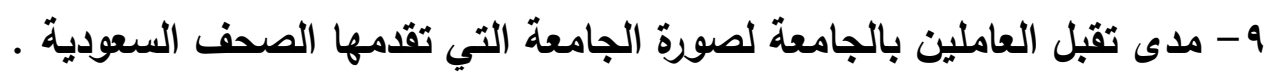

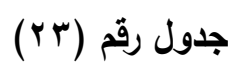

\begin{tabular}{|c|c|c|}
\hline$\%$ & كs & مدى تقبل العاملين بالجامعة لصورة الجامعة بالصحف \\
\hline rq.० & or & صورة مقبولة إلى حد كبير \\
\hline M. & $\varepsilon 9$ & صورة مقبولة إلى حد ما \\
\hline rr.q & rr & صورة مرفوضة \\
\hline $1 \ldots$ & צ & المجموع \\
\hline
\end{tabular}

تكرارات ونسب مدى تقبل العاملين بالجامعة لصورة الجامعة التي تقدمها الصحف السعودية.

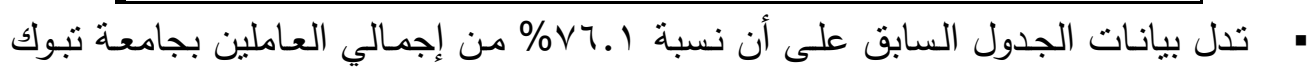

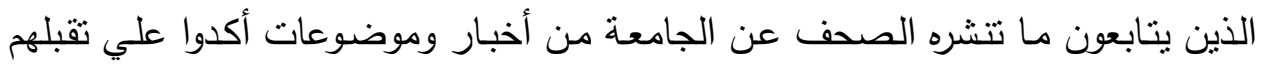

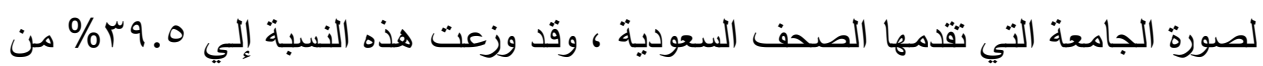
إجمالي العاملين بجامعة تبوك الذين يتابعون ما تتشره الصحف عن الجامعة من أخبار 
وموضوعات برون أن هذه الصورة مقبولة إلي حد كبير ، ونسبة ج. ؟ب\% يرون أن هذه

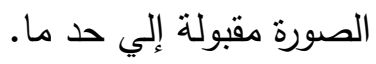

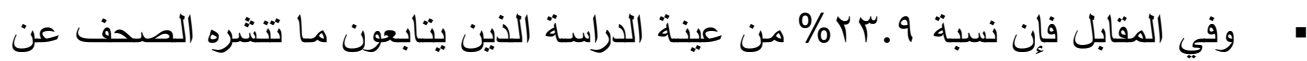
الجامعة من أخبار وموضوعات يرون أن الصورة التي تقدمها الصحف للجامعة مرفوضة

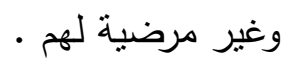

• 1 - الجهود التي تبذلها الجامعة لتحسين صورتها لاى منسوبيها من وجهة نظر

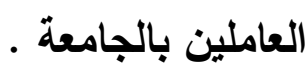

جدول رقم (ع ب) تكرارات ونسب الجهود التي تبذلها الجامعة لتحسين صورتها لاى منسوبيها.

\begin{tabular}{|c|c|c|}
\hline$\%$ & ك & الجهود التي تبذلها الجامعة لتحسين صورتها \\
\hline 17.1 & rv & تقديم الرعاية الصحية لمنسوييها \\
\hline ץч.А & 09 & إتاحة فرص التدريب في التخصص \\
\hline $11 . \varepsilon$ & ro & توفير برامج ترفيهية مناسبة \\
\hline 19.0 & $\varepsilon r$ & توفير فرص المشاركة في المعارض والمؤتمرات \\
\hline$r \cdot .0$ & IV & الدعم والتشجيع للمتميزين \\
\hline «1.1 & 9r & عقد لقاءات دورية مع منسوييها \\
\hline rr.r & vi & مناقشة احتياجات منسويي الجامعة \\
\hline \multicolumn{2}{|c|}{ rr. } & الإجمالي \\
\hline
\end{tabular}

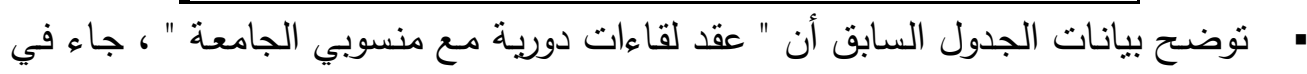
مقدمة الجهود التي تبذلها الجامعة لتحسين صورتها لدى منسوبيها من وجهة نظر لنه العاملين

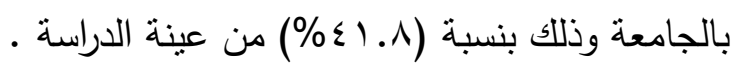

وفي الترتيب الثاني للجهود التي تبذلها الجامعة لتحسين صورتها لدئ لدى منسوبيها من وجهة

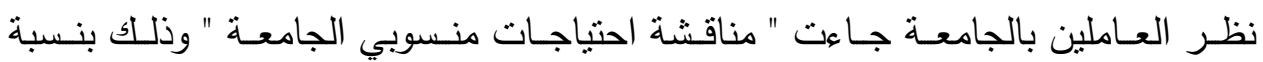

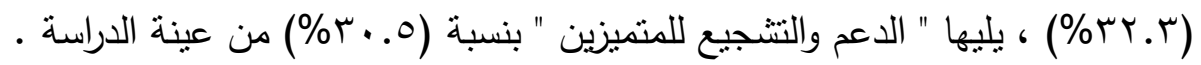

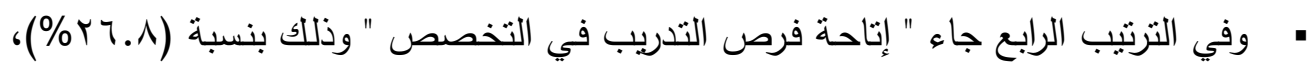
ثم " توفير فرص المشاركة في المعارض والمؤتمرات " بنسبة بلغت (9.0 (1\%) من العينة

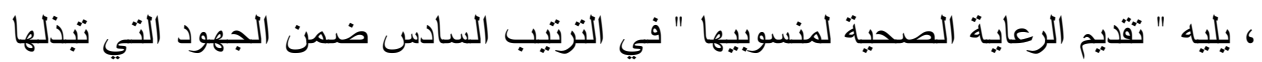

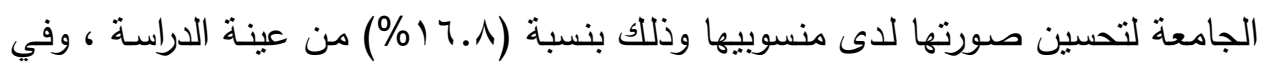
الترتيب الأخير جاء " توفير برامج نرفيهية مناسبة " بنسبة (ع. (1\%) من العينة . 
1 ا - استجابات أفراد العينة حول العبارات التي تتناول أداء الجامعة. جدول رقم (ro)

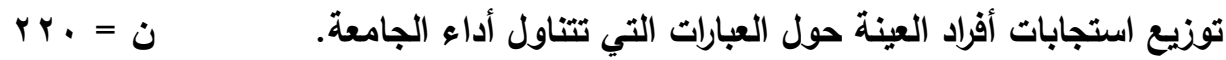

\begin{tabular}{|c|c|c|}
\hline \multicolumn{2}{|c|}{ 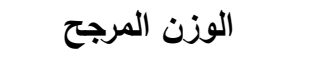 } & \multirow{2}{*}{ توزيع استجابات أفراد العينة حول العبارات التي تتناول أداء الجامعة } \\
\hline الوزن المئوي & النقاط & \\
\hline$\varepsilon . \mu V$ & $\leqslant Y q$ & تستمد الجامعة تميزها من قرتها علي تطوير الأداء \\
\hline $0 . \leqslant 0$ & OrI & تهتم الجامعة بتوفير جو علمي مناسب لأعضاء هيئة التريس \\
\hline $0 . \wedge 1$ & $\leqslant 90$ & يسود مبدأ تكافؤ الفرص بين منسويي الجامعة \\
\hline$\varepsilon . .0$ & $r q 0$ & تتيح الجامعة الفرصة للجميع في الابتكار والإبداع في الأداء \\
\hline$\varepsilon . V \varepsilon$ & $\{7 r$ & ترحب الجامعة بالانتاج العلمي المتميز لأعضاء هيئة التدريس \\
\hline $0.0 \mathrm{~V}$ & $0 \leqslant r$ & تتعاون إدارات الجامعة وموظفيها في القضاء علي مشاكل منسوييها \\
\hline $0 . Y_{1}$ & 011 & توجد قنوات اتصال متاحة بين إدارة الجامعة ومنسوييها \\
\hline $0 . Y Y$ & 0.9 & يوجد ترابط بين الأقسام الأكاديمية والإدارية بالجامعة يشري العمل \\
\hline$\varepsilon . \vee V$ & $\leqslant 70$ & تحرص الجامعة علي دعم قررات ومهارات منتسبيها بالتدريب \\
\hline$\varepsilon .71$ & $\{07$ & الجامعة حريصة على استقطاب أفضل أعضاء هيئة التدريس \\
\hline $0 . .0$ & $\leqslant q r$ & الجامعة تسعي دائما إلي تنمية مهارات منسوييها \\
\hline $0 . \cdot 1$ & $\leqslant 90$ & تهتم الجامعة بخدمة وتلبية احتياجات المجتمع المحلي \\
\hline $0 . \leqslant V$ & orr & تحرص الجامعة علي إقامة شراكات حقيقية مع مؤسسات المجتمع \\
\hline$\varepsilon .7 r$ & $\leq 0$. & تثمن الجامعة الثراكات العلمية والتعاون الأكاديمي في مختلف برامجها \\
\hline 0.7 & $0 \leq 7$ & تثمن الجامعة الجها الذي ييذله منسوييها من أعضاء هيئة التدريس \\
\hline $0 . Y \leq$ & 011 & تطبق نظم تقييم الأداء بشفافية علي الجميع \\
\hline 0. Yo & $01 Y$ & توفر الجامعة معينات التدريس الللازمة للعمل بكفاءة \\
\hline$\varepsilon . V_{0}$ & $\leq 7 r$ & توفر الجامعة الاعم المعنوي لمنتسبيها من أعضاء هيئة التدريس \\
\hline$\varepsilon . V_{1}$ & \&०१ & البنية التحتية للجامعة جيدة وتساعد علي الأداء المتميز \\
\hline $0 . .7$ & $\leqslant q 4$ & خدمات الرعاية الصحية التي تقدمها الجامعة كافية \\
\hline & $9 \vee \leq 9$ & 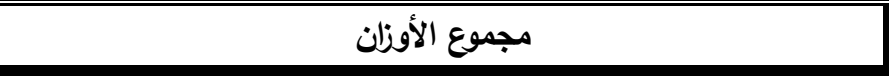 \\
\hline
\end{tabular}


يتضح من بيانات الجدول السابق ما يلي : • أن عبارة " تثمن الجامعة الجهد الذي يبذله منسوبيها من أعضاء هيبئة التدريس والموظفين

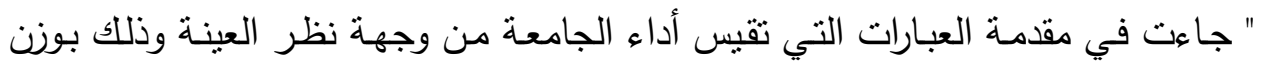

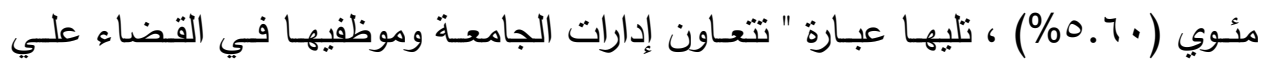

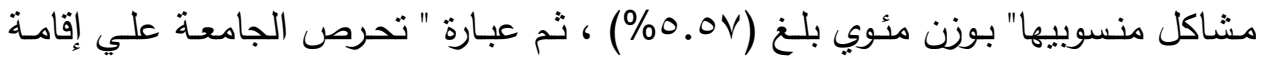

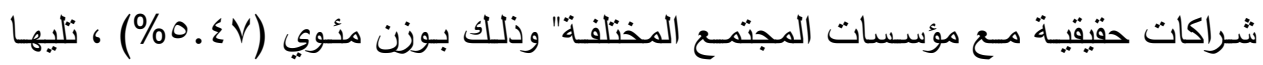

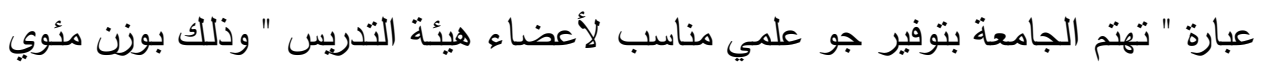

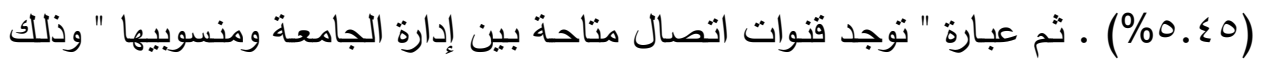

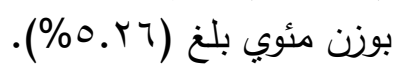

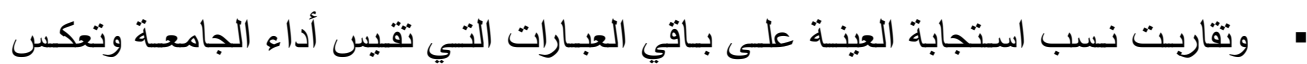

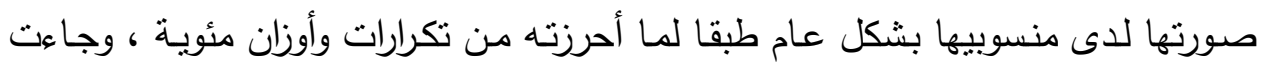

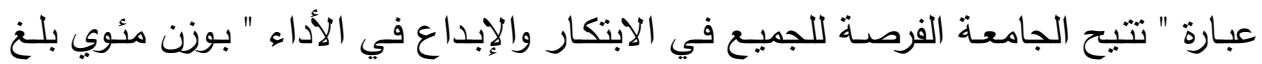

$$
\text { . }(\% £ .0)
$$

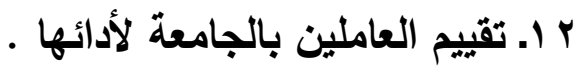

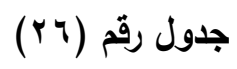

\begin{tabular}{|c|c|c|}
\hline$\%$ & ك & تقييم العاملين بالجامعة لأدائها \\
\hline rV.r & 7. & مؤسسة تؤدي دورها بكفاءة عالية \\
\hline rr.r & $V \mu$ & مؤسسة ذات أداء جيد \\
\hline 19.0 & $\varepsilon r$ & مؤسسة ذات أداء متوازن \\
\hline$\Lambda . r$ & 11 & مؤسسة ذات أداء مقبول \\
\hline 11.1 & YT & مؤسسة ذات أداء ضعيف \\
\hline $1 \ldots$ & rr. & الإجمالي \\
\hline
\end{tabular}

توزيع آراء العاملين بالجامعة لأدائها ـ جأ

تشير نتائج الجدول السابق إلي أن الأداء الجيد جاء في مقدمـة أنواع تقيهم العاملين

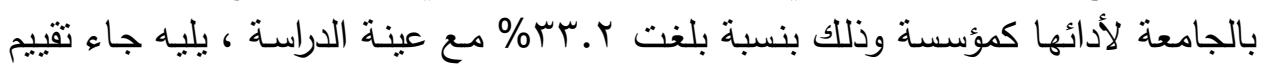

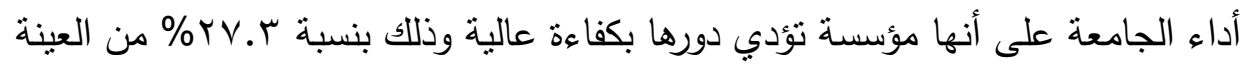

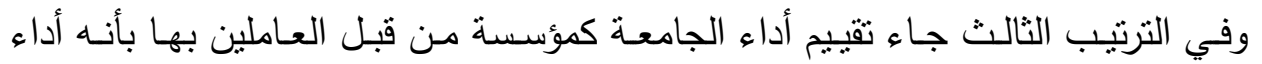

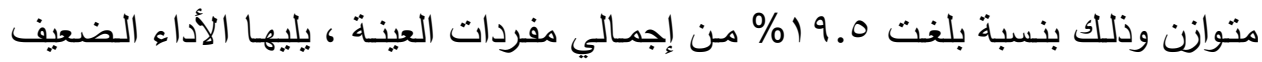

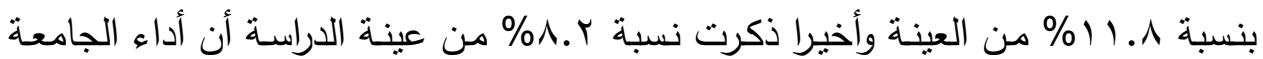




\section{نتائج التحقق من صحة الفروض :}

الفرض الأول للاراسة ؛ والذي ينص علي أنه " توجد علاقة دالة إحصائيا بين تعرض

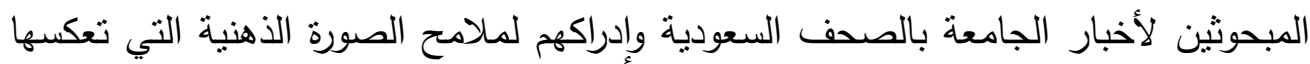

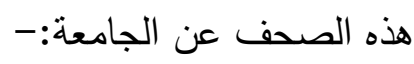

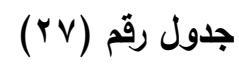

معامل ارتباط بيرسون بين تعرض المبحوثين لأخبار الجامعة بالصحف السعودية وإدراكهم لملامح الصورة الذهنية التي تعكسها هذه الصحف عن الجامعة.

\begin{tabular}{|c|c|c|c|c|c|c|}
\hline \multicolumn{3}{|c|}{ الملامح السلبية } & \multicolumn{3}{|c|}{ الملامح الإيجابية } & \multirow[t]{2}{*}{ مملاتح الصورة } \\
\hline $\mathbf{N}$ & $\mathbf{P}$ & $\mathbf{R}$ & $\mathrm{N}$ & $\mathbf{P}$ & $\mathbf{R}$ & \\
\hline 0 \& & ש זום. & $\ldots .79$ & $11 \%$ & $\ldots .1$ & A & درجة لأخبار الجامعة بالصحف \\
\hline
\end{tabular}

تثير نتائج الجدول السابق أنه باستخدام معامل ارتباط بيرسون أتضح وجود علاقة دالة بين درجة تعرض المبحوثين لأخبار الجامعة في الصحف السعودية وإدراك الملامح الإيجابية للصورة الذهنية للجامعة التي تعكسها الصحف عن الجامعة لديهم حيث بلغت قيمة معامل

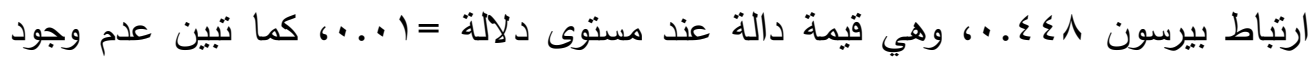

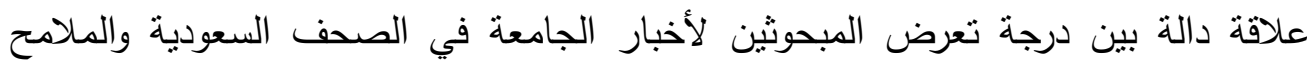
السلبية للصورة الذهنية للجامعة التي تعكسها هذه الصحف عن الجامعة لديهم حيث بلغت

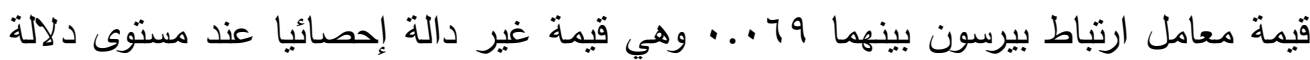

وتأسيساً علي ذلك يمكن القول أن التعرض للصحف وما تتشره من أخبار وموضوعات عن الجامعة يؤدي إلى إدراك الكثير من الملامح الإيجابية لصورة الجامعة لدى العاملين بها

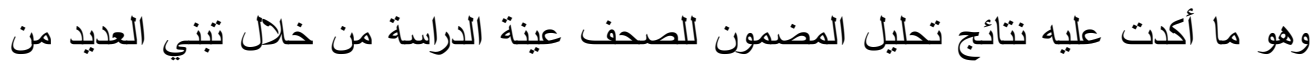
الصحف لاتجاهات إيجابية نحو الجامعة فيما تتشره عن الجامعة بشكل واضح، وبذللك يمكن القول أنه كلما إزداد التعرض لأخبار الجامعة بهذه الصحف إزداد إدراك الملامح الإيجابية

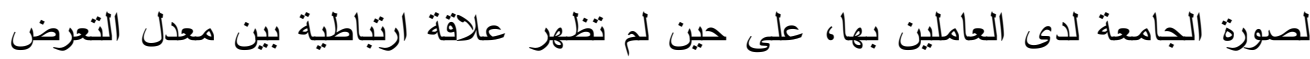
للصحف والملامح السلبية لصورة الجامعة لدى العاملين بها وهو ما يمكن إرجاعه لقلة المواد والمضامين ذات التوجه السلبي نحو الجامعة بصحف الدراسة . 
الفرض الثاني للاراسة؛ والذي ينص علي أنه " توجد علاقة دالة إحصائيا بين معدل تعرض المبحوثين لأخبار الجامعة بالصحف وكل من : م إدراك العاملين بالجامعة لواقعية الصورة المقدمة بالصحف عن الجامعة . م تقبيم العاملين بالجامعة لأدائها ـ

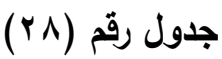

معامل ارتباط بيرسون بين معدل تعرض المبحوثين لأخبار الجامعة بالصحف وكل من ؛ ؛ إدراك

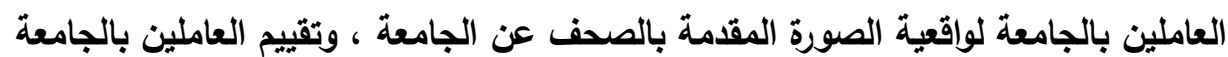

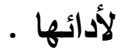

\begin{tabular}{|c|c|c|c|c|c|c|}
\hline \multicolumn{3}{|c|}{ تقييم العاملين بالجامعة لأدائها } & \multicolumn{3}{|c|}{ بالدراك واقعية الصورة المقدمة } & \multirow[t]{2}{*}{ المتغير } \\
\hline $\mathbf{N}$ & $\mathbf{P}$ & $\mathbf{R}$ & $\mathbf{N}$ & $\mathbf{P}$ & $\mathbf{R}$ & \\
\hline 10r & $\cdots$ & **. . Y৭ & Ir & $\cdots$ & **. . & معدل التعرض \\
\hline
\end{tabular}

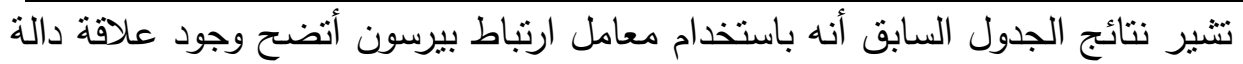
بين معدل تعرض المبحوثين لأخبار الجامعة بالصحف ومدى إدراكهم لواقعية الصورة المقدمة

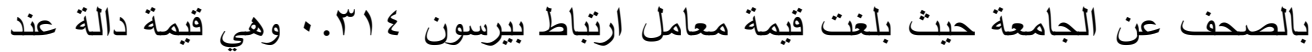

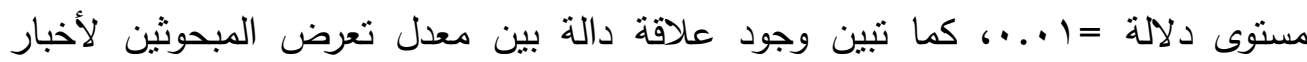

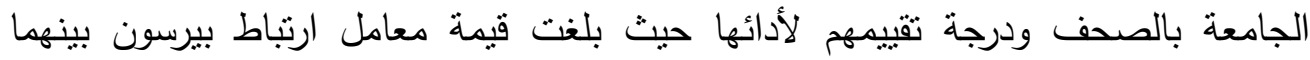

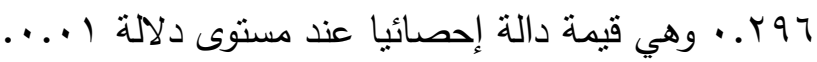

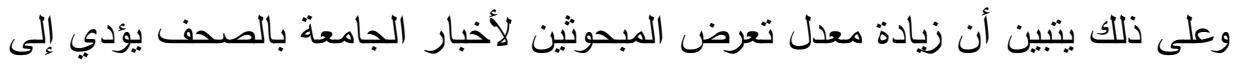

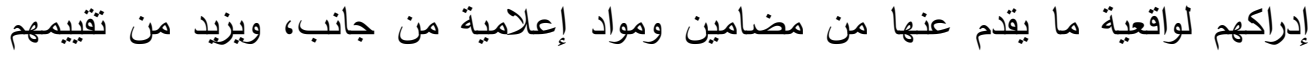

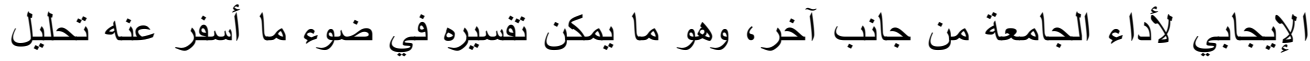
المضمون لهذه الصحف، حيث كثف عن تبني الصحف لنشر الموضوعات الإيجابية عن الجامعة وتتاول تلك الموضوعات في معالجات إخبارية وتفسيرية بشكل أكبر من المعالجات النقدية والتوجيهية.

الفرض الثالث للاراسة؛ والذي ينص علي أنه " توجد فروق ذات دلالة إحصائية بين

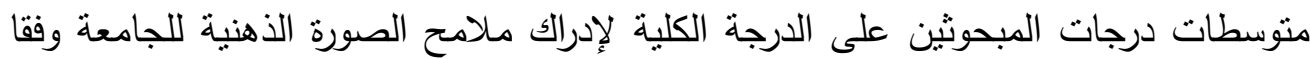

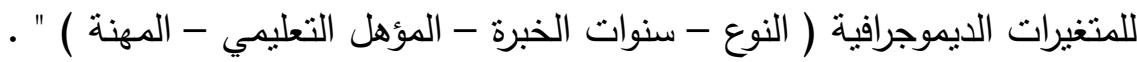

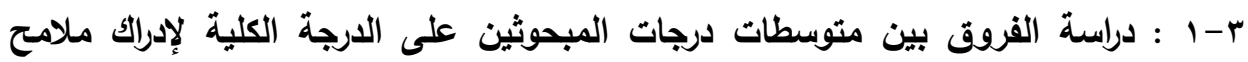

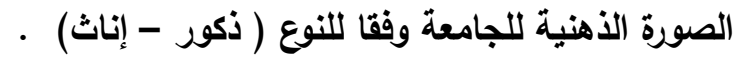




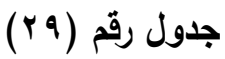

نتائج اختبار (ت) لمعنوية الفروق بين الأكور والإناث علي الارجة الكلية لإدراك ملامح الصورة

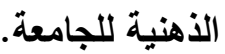

\begin{tabular}{|c|c|c|c|c|c|c|}
\hline الدلالة & قيمة ت & الانحراف & المتوسط & العدد & المجموعات & المتغير \\
\hline \multirow{2}{*}{ غير دالة } & \multirow{2}{*}{..$\leqslant 1-$} & r.Pr & $0 . .0$ & TV & الأكور & \multirow{2}{*}{ الصلاميح الإيجابية } \\
\hline & & 1.95 & 0.41 & $\varepsilon 7$ & الإناث & \\
\hline \multirow{2}{*}{ د. ـ. . . } & \multirow{2}{*}{ Y. $\leqslant V-$} & ד & r.IA & rr & الذكور & \multirow{2}{*}{ الصورة الجامعة السلبية } \\
\hline & & 1.91 & $r .1 r$ & rr & الإناث & \\
\hline
\end{tabular}

تشير نتائج تطبيق اختبار "ت" إلي عدم وجود فروق ذات دلالة إحصائية بين متوسطات

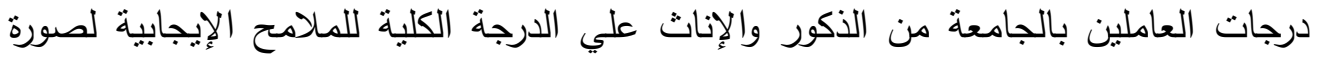

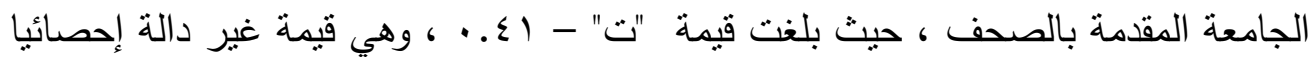

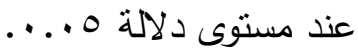

كما توضح النتائج وجود فروق ذات دلالاتة إحصائية بين متوسطات درجات العاملين

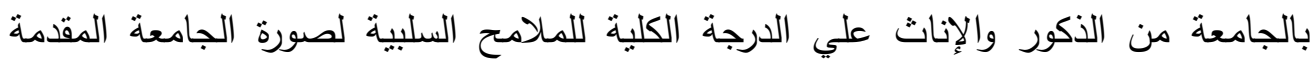

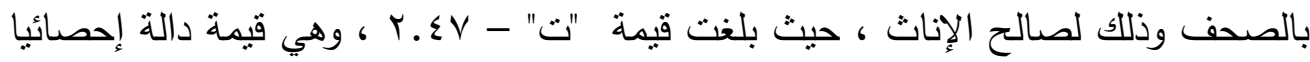

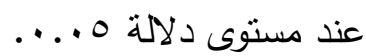
r-r ب دراسة الفروق بين متوسطات درجات مجموعات العاملين بالجامعة في الارجة

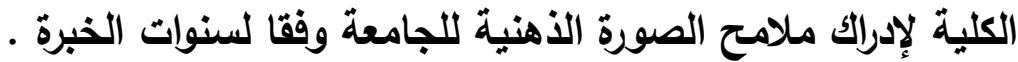

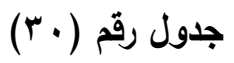

تحليل التباين أحادي الاتجاه بين متوسطات درجات مجموعات العاملين بالجامعة في

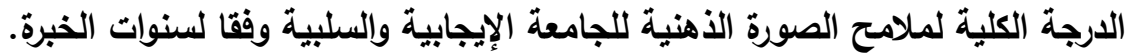

\begin{tabular}{|c|c|c|c|c|c|c|}
\hline الدلالة & فيمة & متوسط & الدرية & المربعوعات & مصدر التباين & المتغير \\
\hline \multirow{3}{*}{ غير } & \multirow{3}{*}{$1 . r \varepsilon$} & 0.100 & $r$ & $1 . .011$ & بين المجموعات & \multirow{3}{*}{ الإيجابية لصورة } \\
\hline & & $r . q . v$ & 11. & $\varepsilon r q . \vee 00$ & المجموعات & \\
\hline & & & $11 \%$ & $\varepsilon \varepsilon$. Y & المجموع & \\
\hline \multirow{3}{*}{ غير } & \multirow{3}{*}{.94} & $1.9 \times 1$ & r & $r . \wedge 07$ & بين المجموعات & \multirow{3}{*}{ لصلاميح السلبية } \\
\hline & & r.1.0 & 01 & I.V.r $\quad 1$ & داخل المجموعات & \\
\hline & & & or & $111 . r . \varepsilon$ & المجموع & \\
\hline
\end{tabular}


تنشير نتائج الجدول السابق إلي عدم وجود فروق دالة إحصائيا بين منوسطات درجات

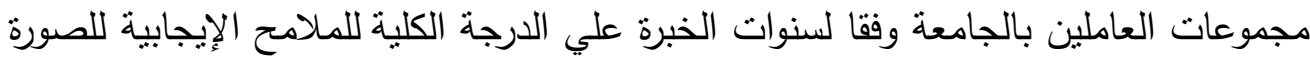

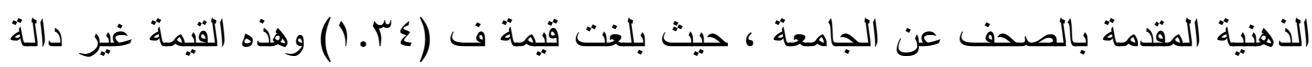

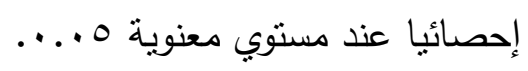

كما تبين عدم وجود فروق دالة إحصائيا بين متوسطات درجات مجموعات العاملين

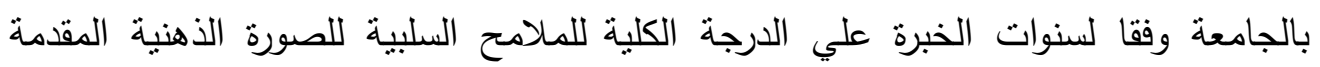
بالصحف عن الجامعة، حيث بلغت قيمة ف (ب9. . ) علي المقياس في الدرجة الكلية ، وهذه

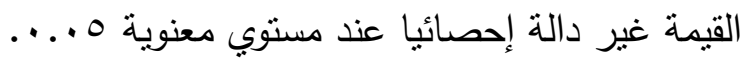
r r r r ب دراسة الفروق بين درجات مجموعات العاملين بالجامعة في الارجة الكلية لإدراك

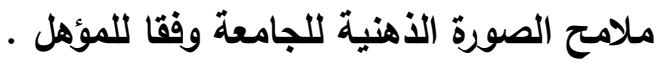

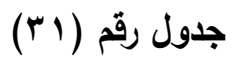

تحليل التباين أحادي الاتجاه بين درجات مجموعات العاملين بالجامعة في الارجة الكلية

\begin{tabular}{|c|c|c|c|c|c|c|}
\hline الدلالة & قيمة & المربعات & الحرية & مجموعات & مصدر التباين & المتغير \\
\hline \multirow{3}{*}{ غالة } & \multirow{3}{*}{. ro } & $1 . .47$ & $\varepsilon$ & $\leqslant .1 \leqslant r$ & بين المجموعات & \multirow{3}{*}{ لصورة الجامعة الإيجابية } \\
\hline & & $\varepsilon .+r \Lambda$ & $1 \cdot 1$ & r & داخل المجموعات & \\
\hline & & & $11 r$ & $\varepsilon \varepsilon . . Y 70$ & المجموع & \\
\hline \multirow{3}{*}{ غالة } & \multirow{3}{*}{ 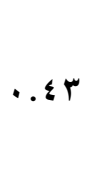 } & 901. & $\varepsilon$ & $r . \wedge .0$ & بين المجموعات & \multirow{3}{*}{ الصورة الجامعة السلبية } \\
\hline & & r.19r & $\leqslant 9$ & I.V.rq1 & داخل المجموعات & \\
\hline & & & or & 111.r. & المجموع & \\
\hline
\end{tabular}

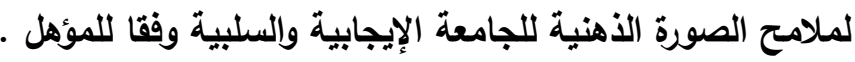

تشير نتائج الجدول السابق إلي عدم وجود فروق دالة إحصائيا بين متوسطات درجات

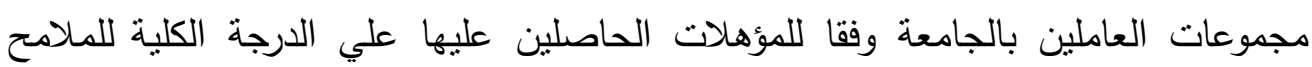

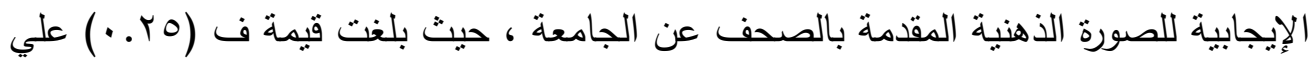

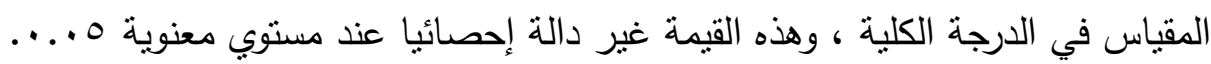

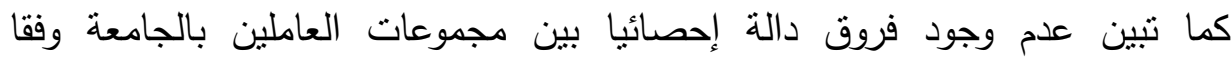

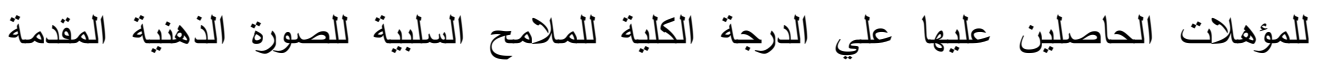
بالصحف عن الجامعة ، حيث بلغت قيمة ف (بـ . ·) علي المقياس في الدرجة الكلية ، وهذه

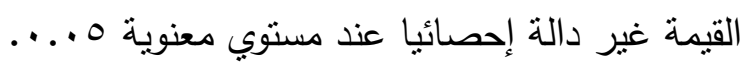


ץ- ؟ : دراسة الفروق بين متوسطات درجات المبحوثين على الارجة الكلية لإدراك ملامح الصورة الذهنية للجامعة للمهنة ( أعضاء هيئة تدريس - موظفين) . جدول رقم (rr)

نتائج اختبار (ت) لمعنوية الفروق بين أعضاء هيئة التدريس والموظفين علي الدرجة الكلية لإدراك

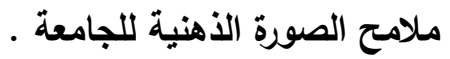

\begin{tabular}{|c|c|c|c|c|c|c|}
\hline الدلالة & قيمة ت & الانحراف & المتوسط & العدد & المجموعات & المتغير \\
\hline \multirow[t]{2}{*}{ غير دالة } & \multirow[t]{2}{*}{...TV } & 1.97 & $0.1 \%$ & TV & أعضاء هيئة & \multirow{2}{*}{ الإليجابية لصورة } \\
\hline & & $r . \cdot r$ & 0.1 . & $\leqslant 9$ & موظقون & \\
\hline \multirow[t]{2}{*}{ غير دالة } & \multirow[t]{2}{*}{$1.7 r$} & $\cdot \vee \wedge \wedge$ & Y.M & rr & أعضاء هيئة & \multirow[t]{2}{*}{ الصورة الجامعة السلبية } \\
\hline & & $r . . r$ & $r .90$ & rr & موظفون & \\
\hline
\end{tabular}

تنتير نتائج تطبيق اختبار "ت" إلي عدم وجود فروق ذات دلالة إحصائية بين العاملين

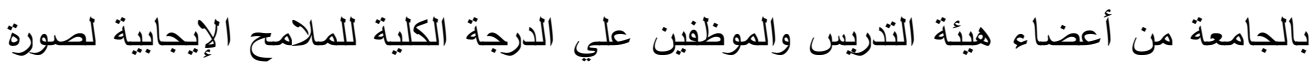
الجامعة المقدمة بالصحف ، حيث بلغت قيمة "ت" لاعل . . . ، وهي قيمة غير دالة إحصائيا

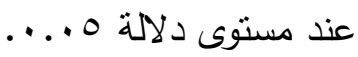
كما توضح النتائج عدم وجود فروق ذات دلات دلالة إحصائية بين العاملين بالجامعة من

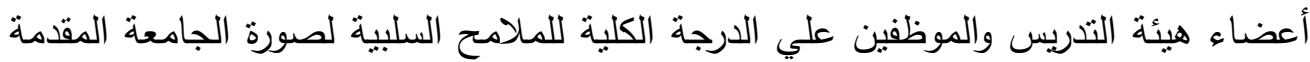

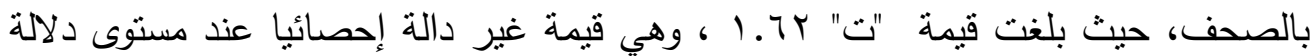
....

الاستنتاجات العامة والتوصبيات :

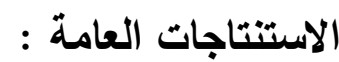

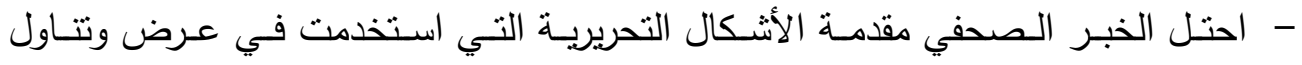

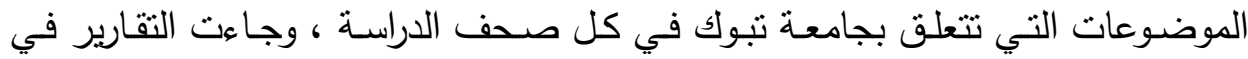

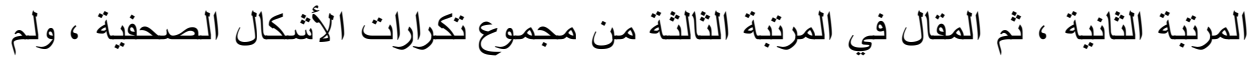
ترد فئة التحقيقات الصحفية في الموضوعات الواردة بالصحف عن الجامعة الصنة خـلال فترة

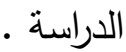
- كشفت الدراسـة أن الـصحف عينـة الدراسـة اعتمـدت في المقـام الأول علـي محرريهـا

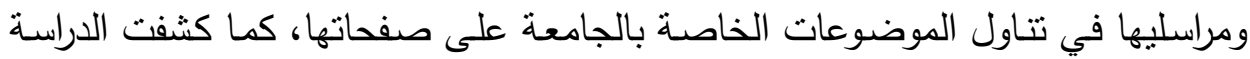


عن ارتفاع تكرارات الموضوعات الواردة عن الجامعة والتي تم تتاولها ومعالجتها صحفيا

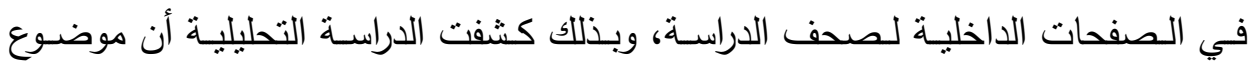

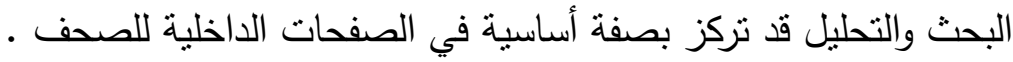

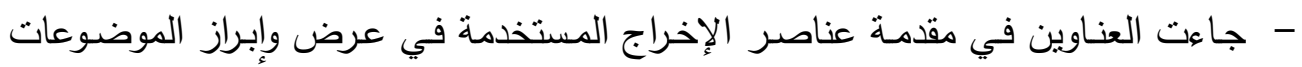

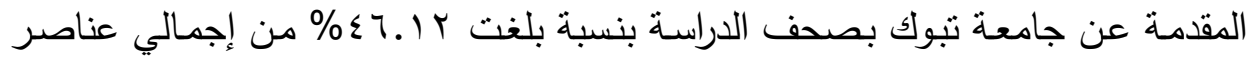

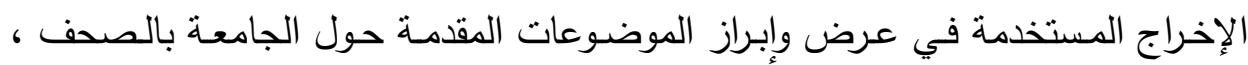

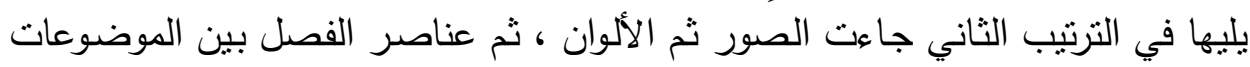

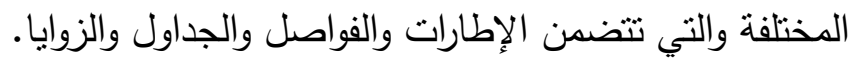

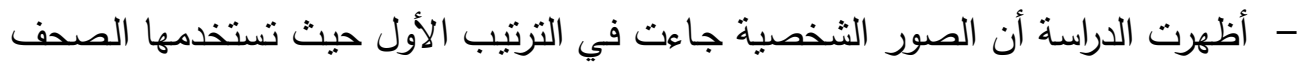

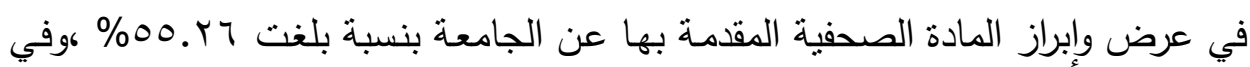

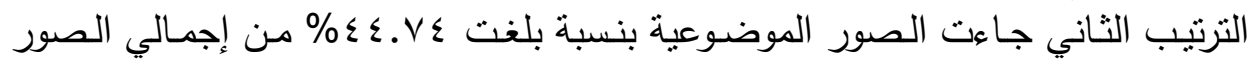

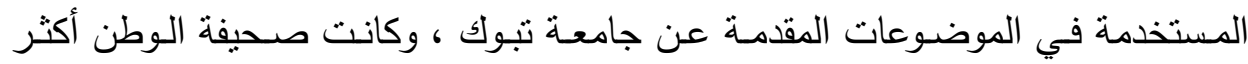

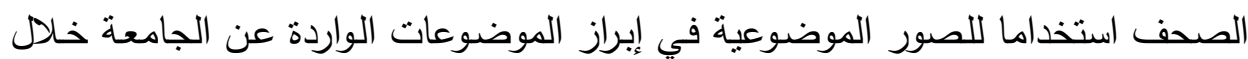
فترة الدراسة . - جاءت المعالجات الإخبارية في المركز الأول من إجمالي تكرارات المعالجات المستخدمة

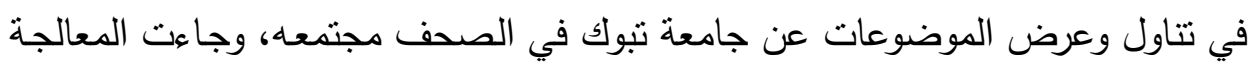

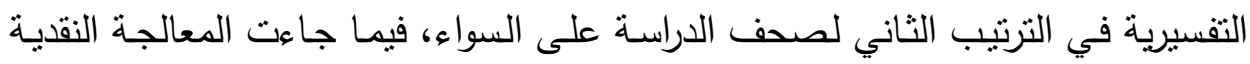

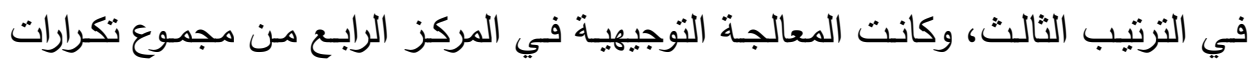

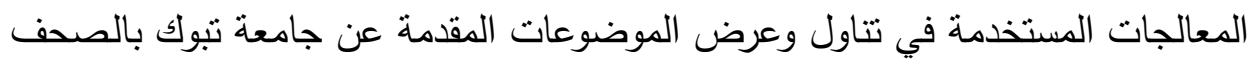
مجتمعة.

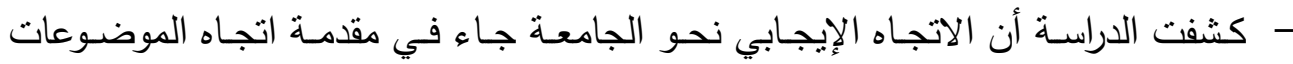

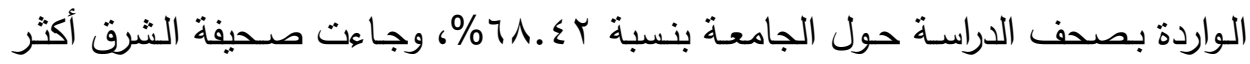

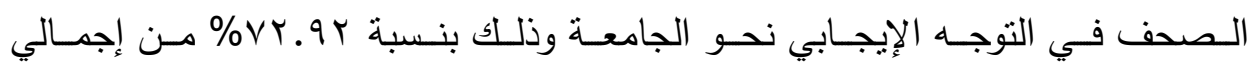

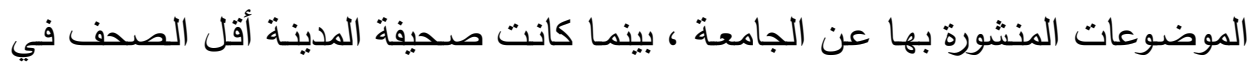

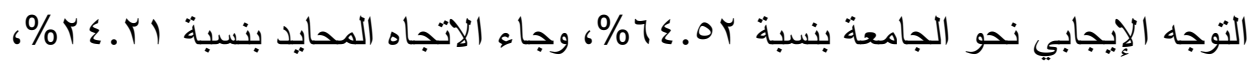

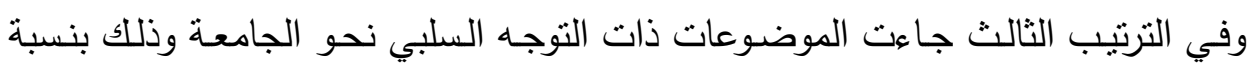
. \%V.rvo

- أظهرت المعالجة الصحفية لصورة جامعة تبوك في الموضوعات الواردة بالصحف عينة

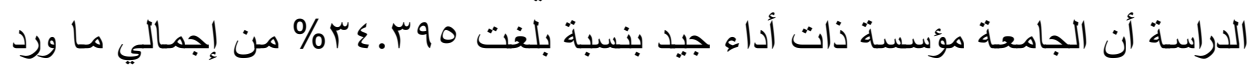

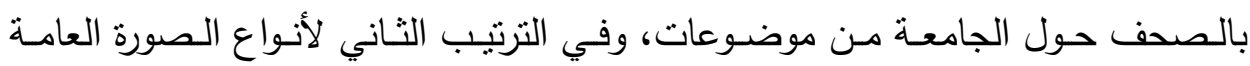

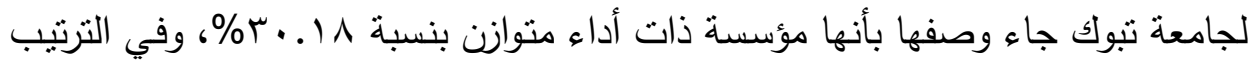

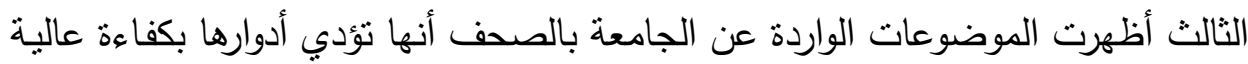




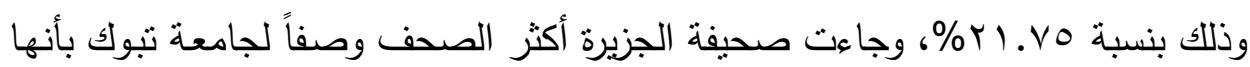

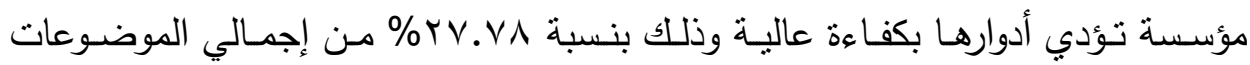

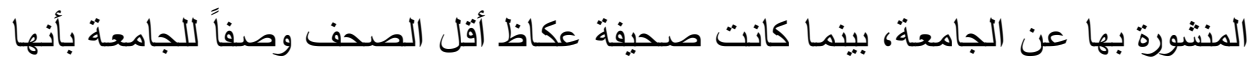

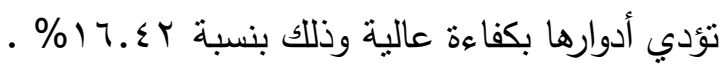

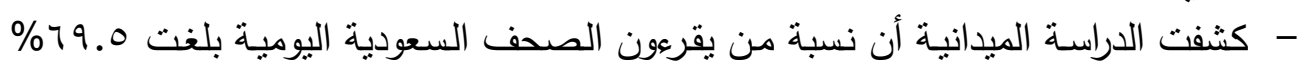

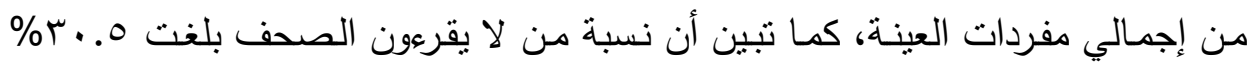

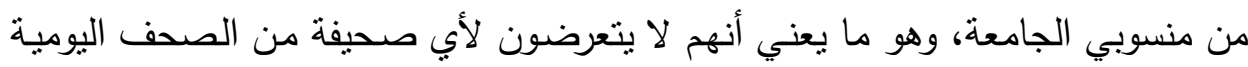

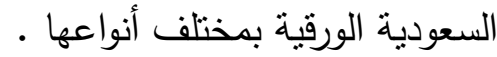

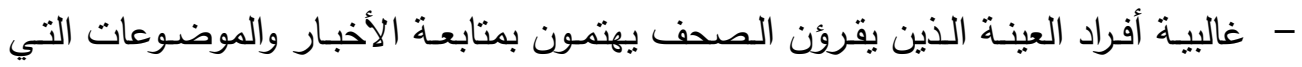

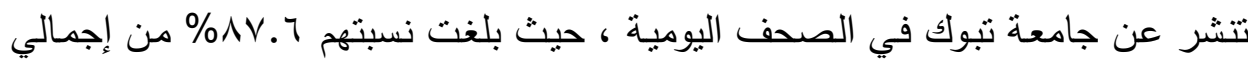

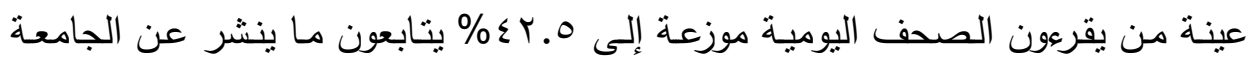

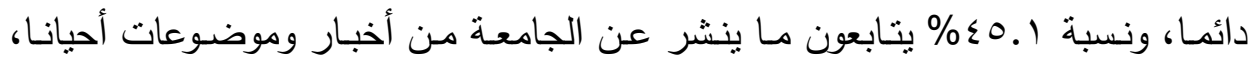

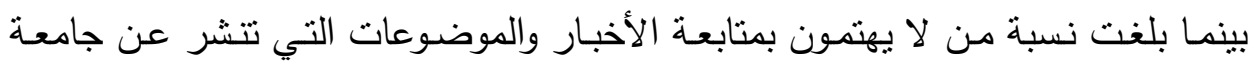

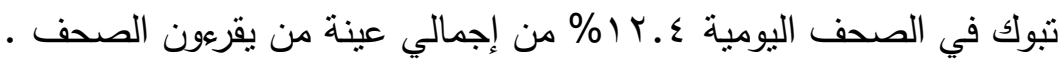

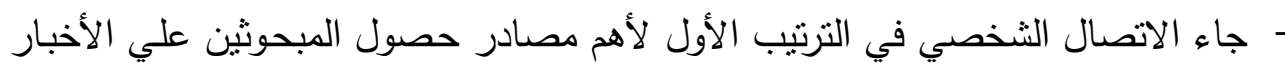

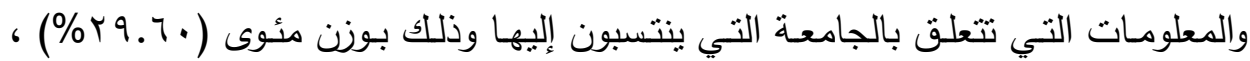

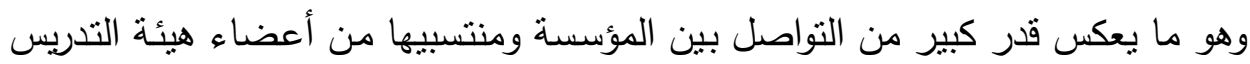

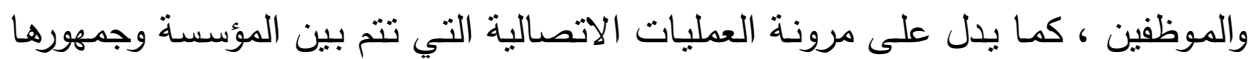
الداخلي . - جاءت عبارة " مؤسسة تمنلك بنية تحتيـة مناسبة " في مقدمة الملامـح الإيجابيـة لصورة

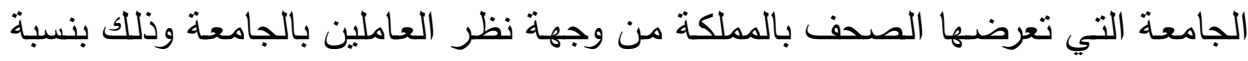

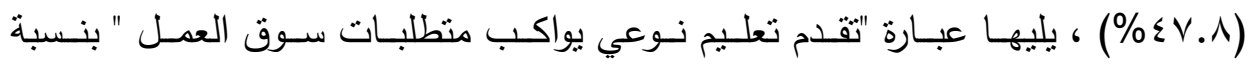

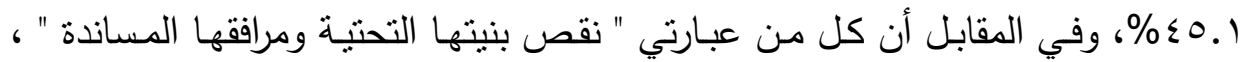

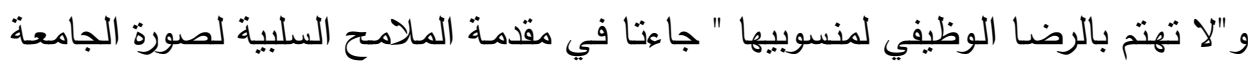

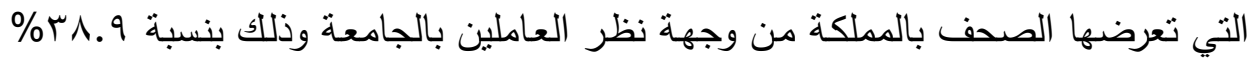

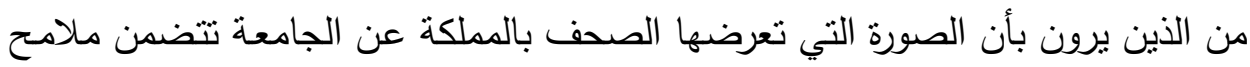
سلبية.

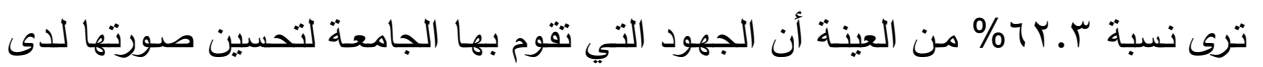

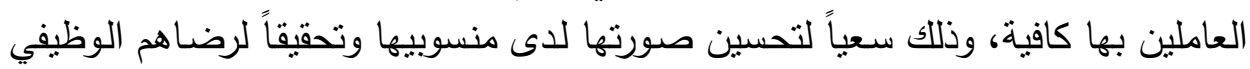

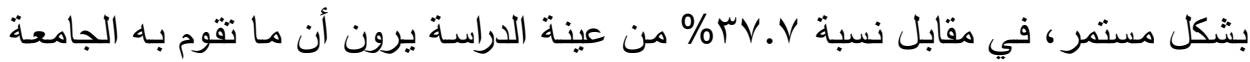

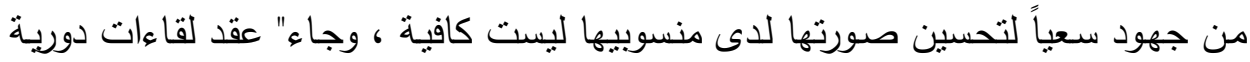




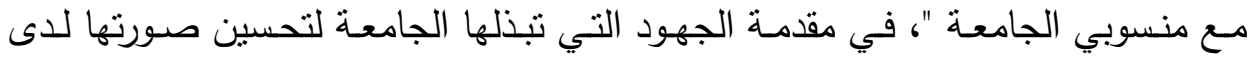

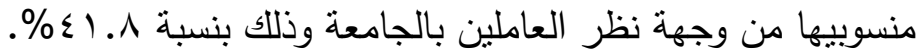

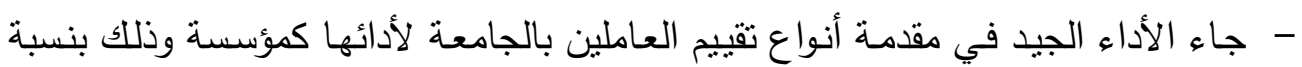

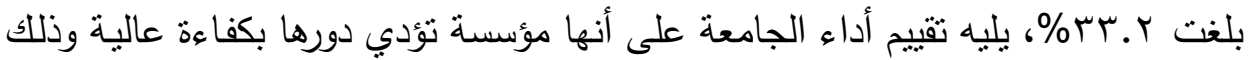

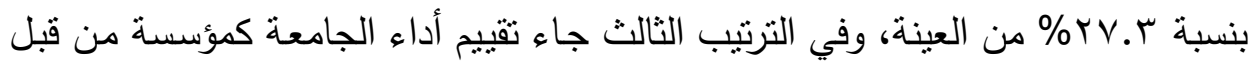

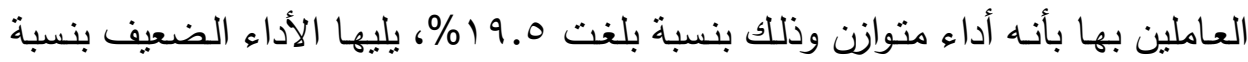

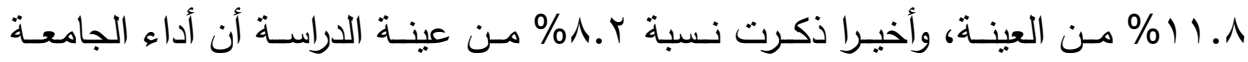
مقبول.

- وجود علاقة ارتباطية دالة إحصائيا بين درجة اهتمـام المبحوثين بمتابعة أخبار الجامعة

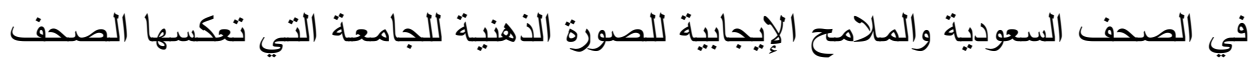
عن الجامعة لديهج، كما تبين عدم وجود علاقة ارتباطية دالة بين درجة اهتمام المبحوثين

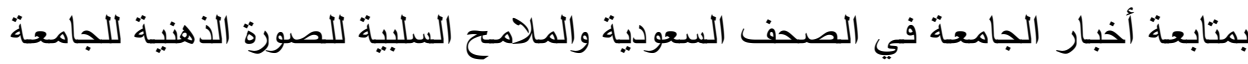
التي تعكسها هذه الصحف عن الجامعة لديهم.

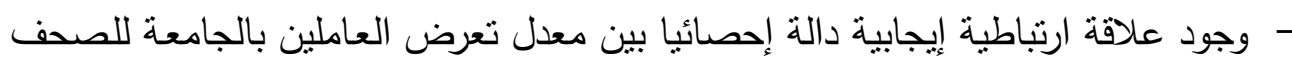

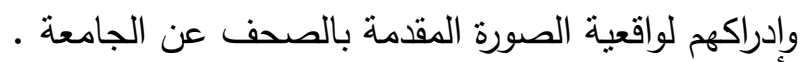
- وجود علاقة ارتباطية إيجابية دالة إحصائيا بين معدل تعرض العاملين بالجامعة لأخبار الجامعة بالصحف ودرجة تقييمه لأداء الجامعة.

توصيات الاراسة :

في ضوء ما سعت الدراسة لتحقيقه من أهداف وما توصلت إليه من نتائج ، توصي الدراسة الحالية بما بلي: الئي:

- إجـراء دراسـات عـن الرضـا الـوظيفي لمنسوبي الجامعـة وذللك للتعـرف على مـا يواجـه العاملين بالجامعة من مشاكل وعقبات والوقوف على كيفبة مواجهتها سعيا لدعم انتماءهم للجامعة التي ينتمون إليها وبعملون بها. - يمثل دعم النمو المهني لمنسوبي الجامعة أحد المداخل المهمة في تحسين صورة الجامعة لـدى العـاملين بهـا وجمهورهـا الـداخلي ويمكن تحقيـق هذا الـدعم للنمـو المهنـي بتقديم النشجيع المادي والمعنوي للكفاءات المهنية، واختيار الكفاءات للترقي، وتوفير مناخ يدعم التمبز والإبداع التعاع 
- تبنـي الجامعـة لبرامج تحسين الصورة الذهنيـة للجامعـة مـن خـلد توفير دورات تدريبيـة

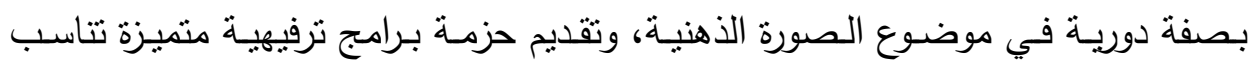
• الجميع

- الاهتمـام بتحقـق أعلى معـدلات نشر للموضـوعات والأنشطة والفعاليـات التي تـدور بالجامعة في الصحف الورقية والإككترونية وهو ما يدعم تبنى العاملين بالجامعة للمزيد

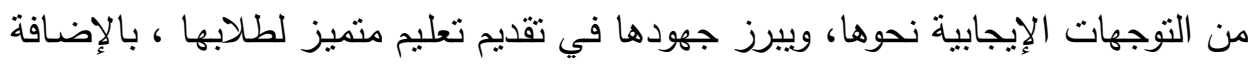

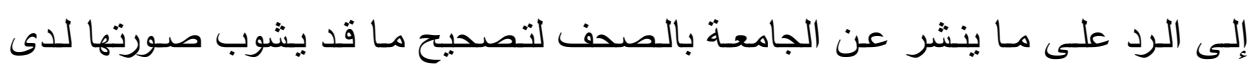

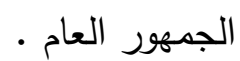

- الاهتمام بوجود وحدة تهتم بمتابعة ما ينشر عن الجامعة من موضوعات بالصحف وشتى

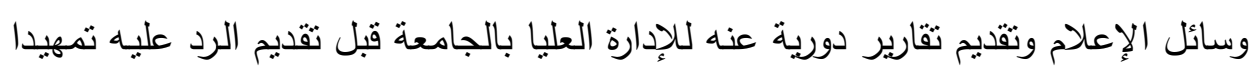

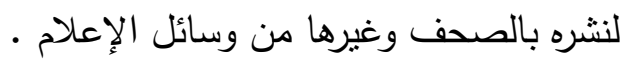
- تنظيم لقاءات دورية منتظمة مع أعضاء هيئة التدريس ومن في حكمه وكذلك الاعلك الموظفين

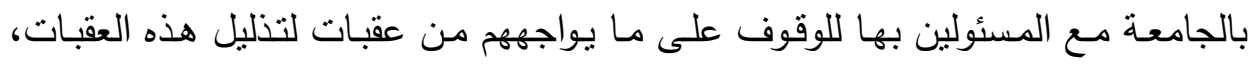
وتبادل الرأي معهم حول كيفية النهوض بالأداء العام داخل كافة وحدات الجامعة .

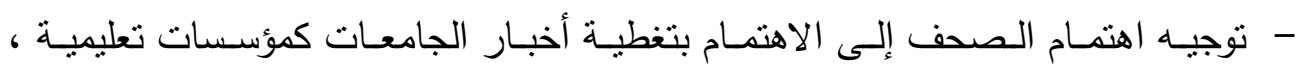

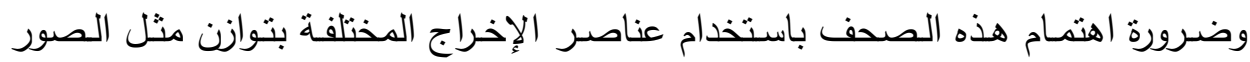

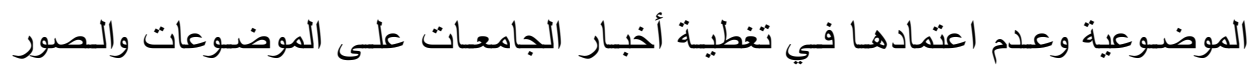

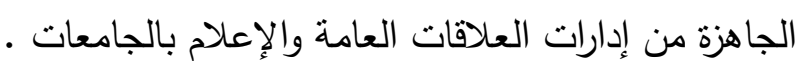

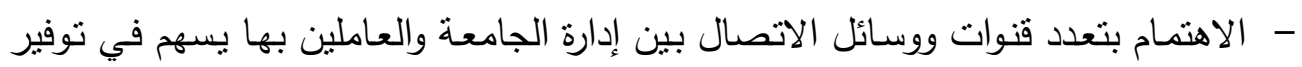
قنوات كافيـة لتمريـر مقترحسات العـاملين بالجامعـة التي ترتبط بتطوير أدائها، وضـمان

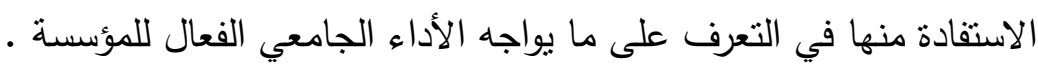


ا. . علي عجوة، كريمان فريد(^ . . ب)، إدارة العلاقات العامة بين الإدارة الاستراتيجية وإدارة

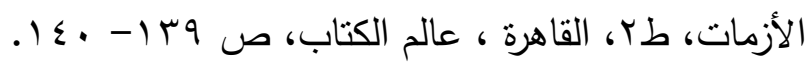

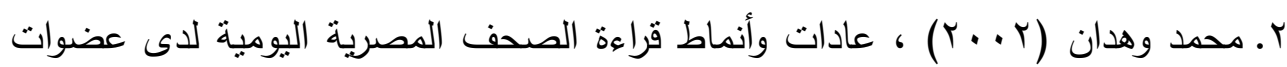

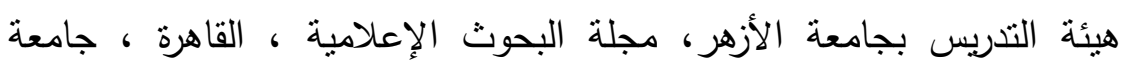

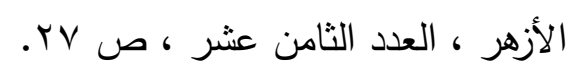

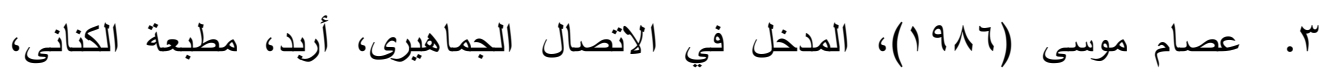

$$
.9 \cdot-\wedge 99 \text { (19人7 }
$$

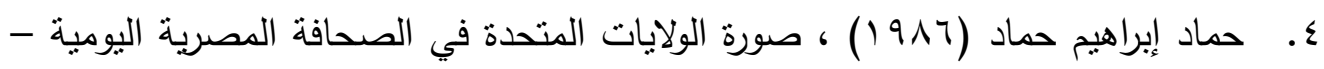
دراسة مقارنة بين حقبة الستينات والسبعينات، رسالة ماجستير غير منشورة، كلية

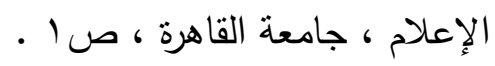

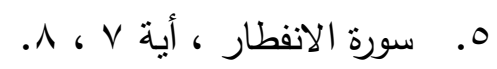

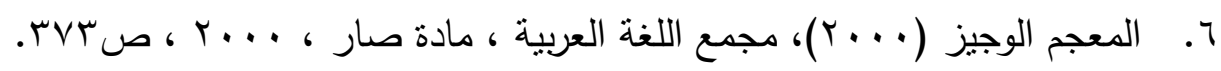

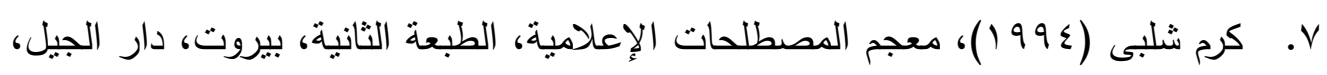

$$
\text { ص صו }
$$

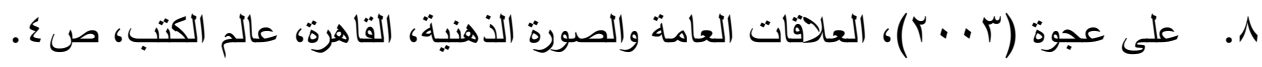

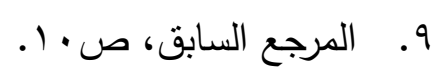

• 1. اعتماد خلف معبد (919 (1)، صورة البطل المقدم للطفل المصري في مجتمع الحرب والسلام ، رسالة دكتوراه غير منشورة ، جامعة عين شمس ، معهر الدراسات

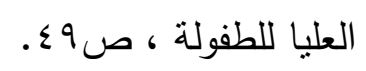

11. سامح محمد محافظه (r99 (1)، صورة الجامعات الأردنية كما يراها رجال الصحافة

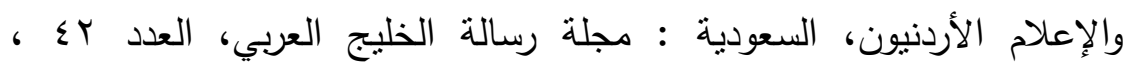

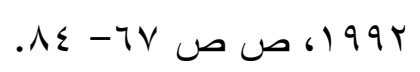

Ir. Bur Bach, H.\&Margo.F,A, (199r), the media profile of image of teacher in film"Teacher Educations. Quarterly vol. ${ }^{\top}$, no.r.

1r. Taylor, C. ( $199 \wedge)$, Image Kindy president in popular culture and classroom, Ph.D. ,Middle Tennessee, State University. 


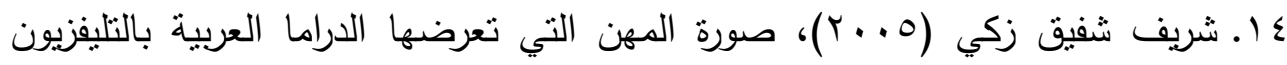
وعلاقتها باتجاهات عينة من المراهقين نحو المهن، رسالة ماجستير غير منشورة، القاهرة، جامعة عين شمس، معهد الدراسات العليا للطفولة. 1 ـ شريفة رحمة الله سليمان(T . . ب)، دور العلاقات العامة في تشكيل الصورة الذهنية للمؤسسات الحكومية من منظور الخدمة الإلكترونية "دراسة حالة إمارة دبي"، رسالة ماجستير، غير منشورة ، جامعة القاهرة: كلية الإعلام، قسم العلاقات العامة والإعلان ד ا ـ سفران بن سفر المقاطي(^ . . ب)، العوامل المؤثرة في تشكيل الصورة الذهنية عن المؤسسات السعودية القائمة على الحج ، مجلة جامعة أم القرى للعلوم التربوية والاجتماعية والانسانية ، مج ، ب، ع ا. V I . حسين محمد الحسيني (N . . r)، دور الصحافة المحلية في دعم الصورة الذهنية للمؤسسات التشربعية لدى الجمهور: دراسة تطبيقية على مجلس الثورى والنواب بمملكة البحرين ، رسالة ماجستير غير منشورة ، الجامعة الأهلية ، كلية الآداب والتربية والعلوم • 1 ا ـ سماح ماضي متولي (^ . . r)، الصورة الإعلامية للمعلم في الصحف المصرية وعلاقتها بتكوين الاتجاهات لدي عينة من المراهقين والمعلمين نحو المعلم، رسالة دكتوراه غير منشورة جامعة عين شمس، معهد الدراسات العليا للطفولة. 9 1 . حنان سعيد هزاع (q . . (Y)، الصورة الذهنية للجامعة لدى المراهقين والمراهقات بالمرحلة الثانوية دراسة مقارنة، رسالة ماجستير غير منشورة، جامعة عين شمس، معهد الدراسات العليا للطفولة. • r . محمد يوسف حجاج(q . . r)، الصورة الذهنية المدركة لبعض المظاهر السلبية للأستاذ الجامعي بكليات التربية البدنية والرياضة في ضوء معايير جودة التعليم العالي

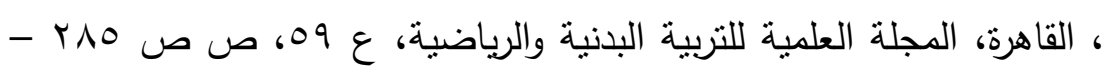
$\cdot r \cdot V$ اب. ممدوح عبدالله محمد(9 . . (Y)، الصورة الإعلامية للحكومة المصرية كما تعكسها البرامج الحوارية في القنوات الفضائية وعلاقتها بالصورة الذهنية للحكومة لدى 
شباب الجامعات، رسالة ماجستير غير منشورة ، جامعة عين شمس ، معهد الدراسات العليا للطفولة .

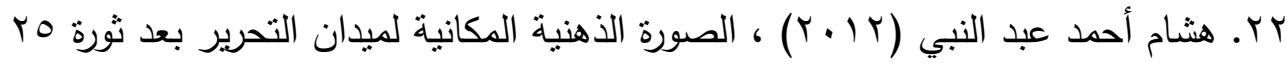
يناير لدى طلاب جامعة الإسكندرية والعوامل المؤثزة في تشكيلها ، مجلة

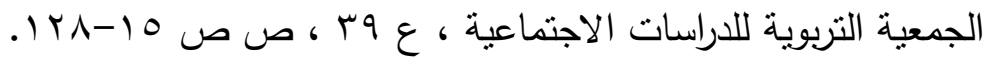
rr. علي عجوة (r . . r) ، العلاقات العامة والصورة الذهنية ، القاهرة، عالم الكتاب، ص .

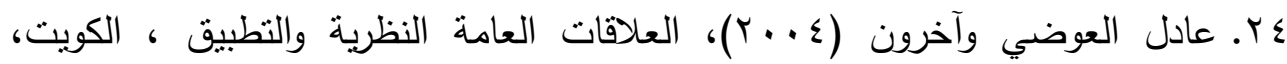

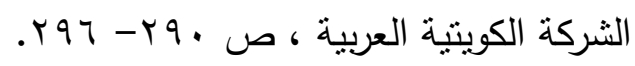

ه . حنان جنيد (99V1 (19) ، العلاقات العامة والتنظيم، مدخل إداري ، القاهرة، مكتبة عين

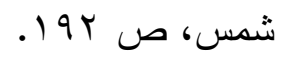

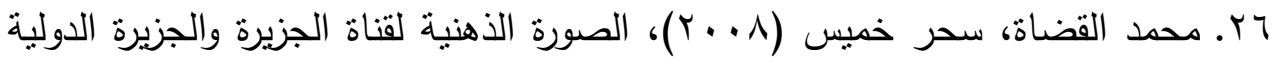
لاى الثباب الجامعي دراسة ميدانية على طلبة جامعتي قطر واليرموك، المجلة

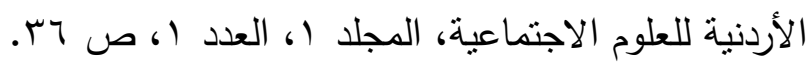

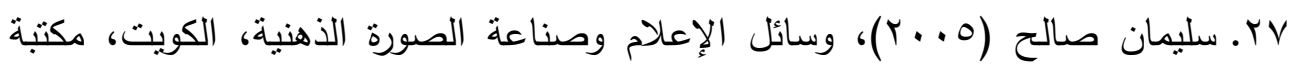

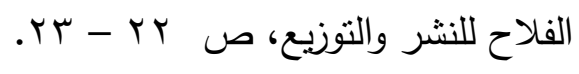

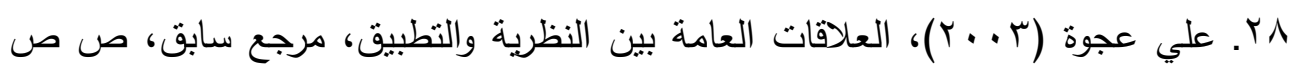

$$
.04-01
$$

rq. Longman Dictionary of English( ( 99 r), 'st published, England, Longman Group uk limited, P. 70^.

• ب. مى الخاجة (999 1) ، دور الاتصال في تكوين الصورة الذهنية للمؤسسات العلاجية في دولة الإمارات العربية المتحدة، المجلة المصرية لبحوث الإعلام، العدد السادس ، جامعة القاهرة، كلية الإعلام، أكتوبر - ديسمبر 999 1، ص • 11. \. Zhoo Jing (1999), the Importance of Image Survey, Improving Effectiveness of communication programs, Public Relation Quarterly, Vol. $\varepsilon \varepsilon$, No.r, PP. rV - r^. 
r r. يامين بودهان (T +. r)، تشكيل الصورة النمطية عن الإسلام والمسلمين في الإعلام

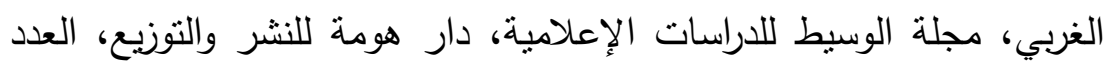

$$
\text { (ל) }
$$

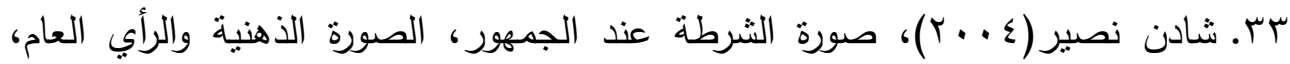

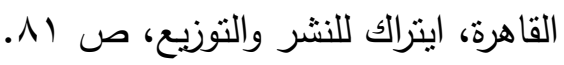

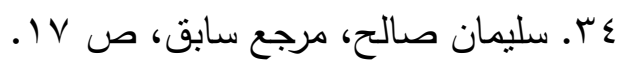

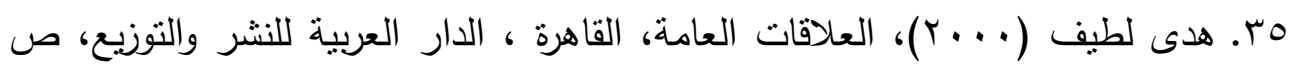
.49

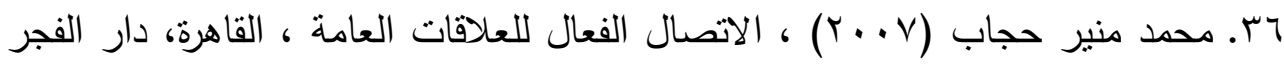

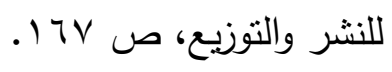

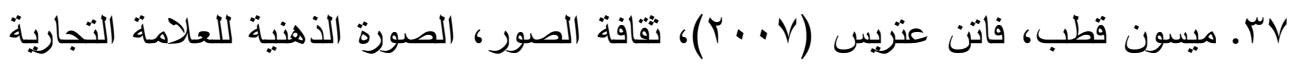

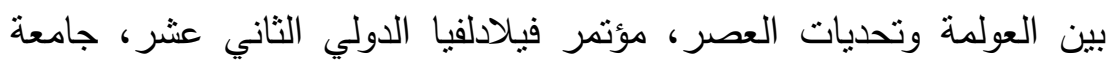

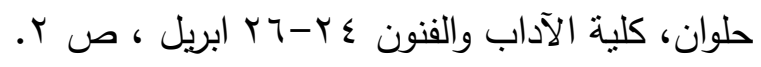

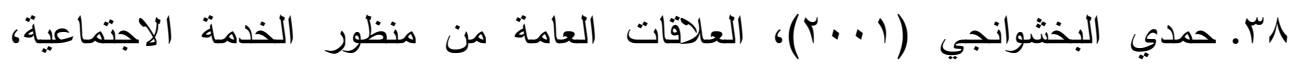

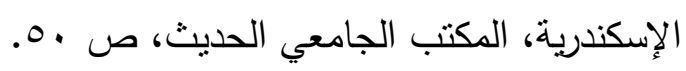

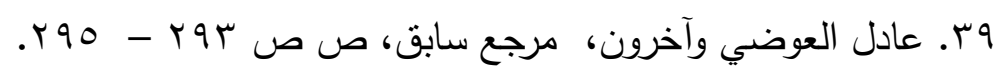

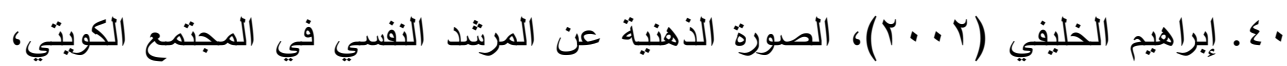

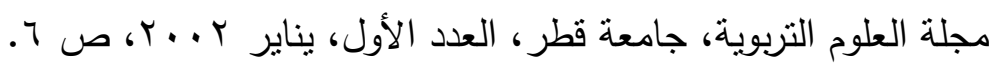

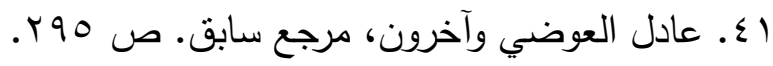

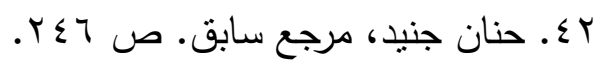

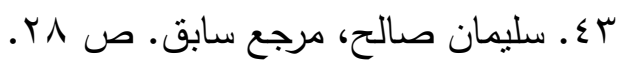

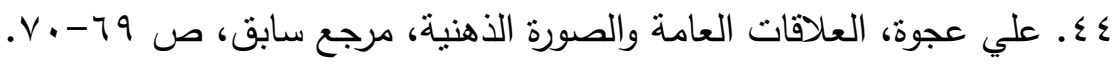

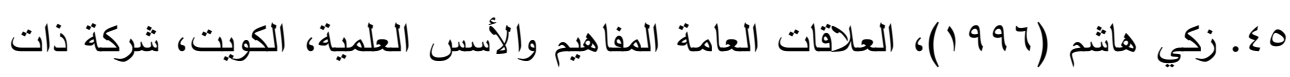

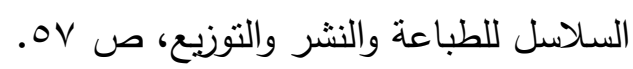
צ §. محمد القضاة، سحر خميس. مرجع سابق ، ص

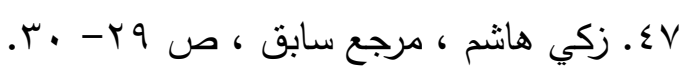




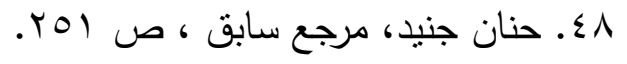

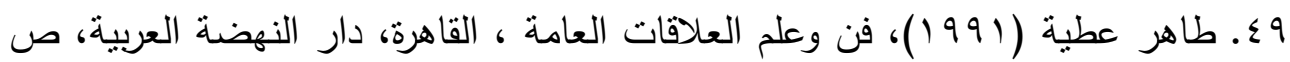
.r. . •. صـ صالح خليل أبو أصبع (9 . . r) ، العلاقات العامة والاتصال الإنساني ، القاهرة ، دار

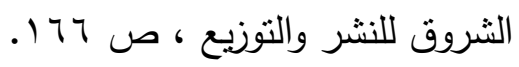

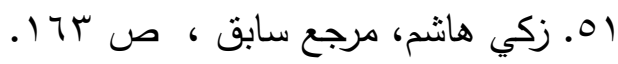

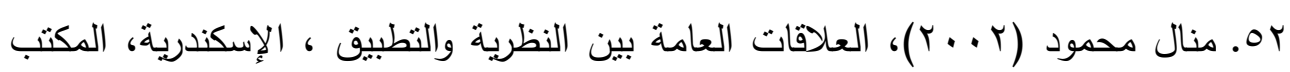

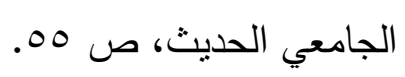

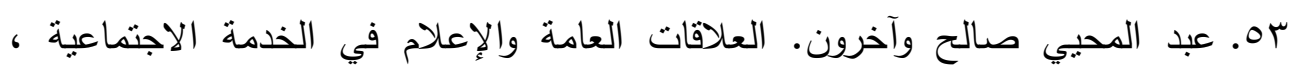

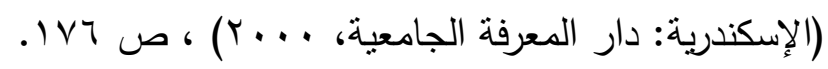

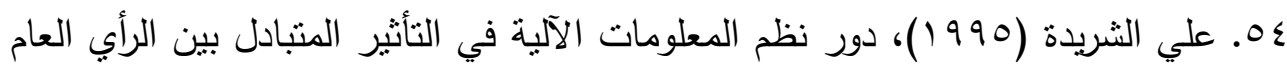

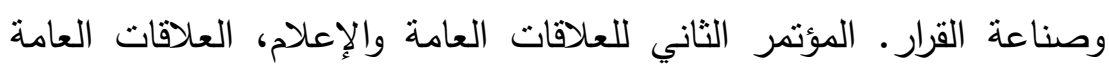
والإعلام في خدمة التتمية، جامعة الكويت، ع- ـ

$$
.1 Y 1
$$

00. همت السقا (•(ب)، دراسات في الإعلام الدبلوماسي والعلاقات العامة، القاهرة،

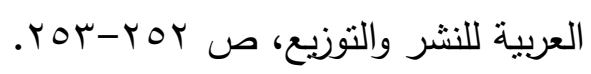

4.

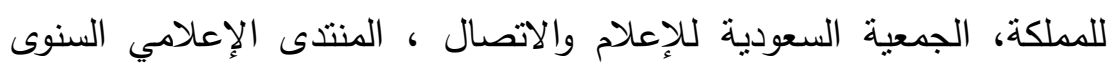

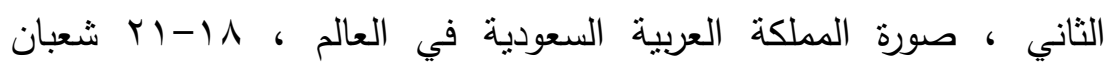

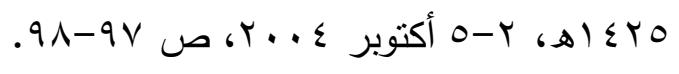

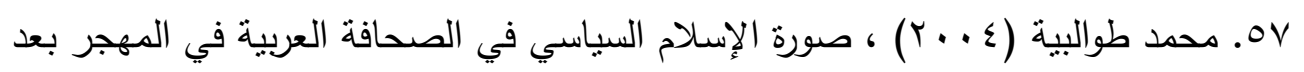

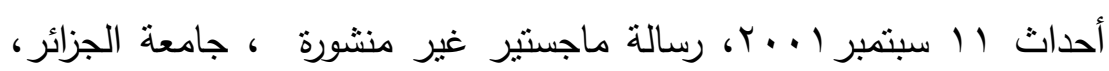

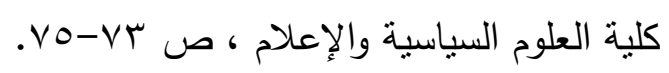

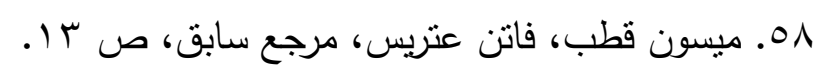

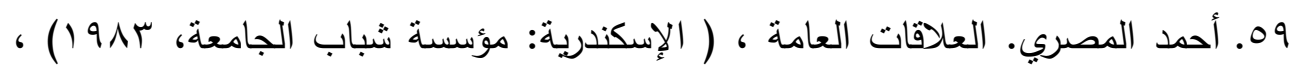


• 7. راسم الجمال، خيرت عياد (990 ())، إدارة العلاقات العامة المدخل الاستراتيجي ،

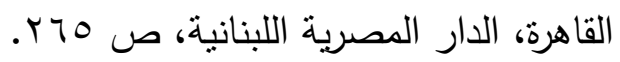

آ7. محمد الصحن (9911)، العلاقات العامة، المبادئ والتطبيق، الإسكندرية، الدار

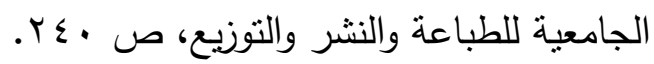

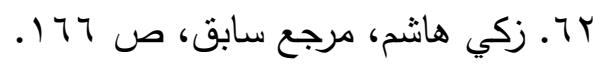

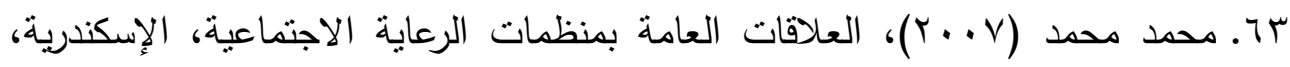

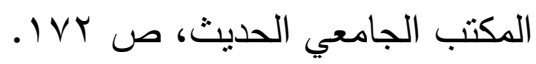

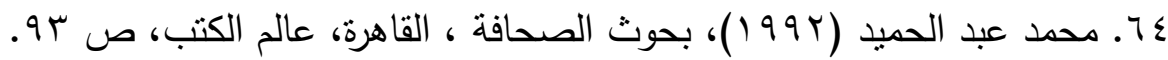

